Historic, Archive Document

Do not assume content reflects current scientific knowledge, policies, or practices. 


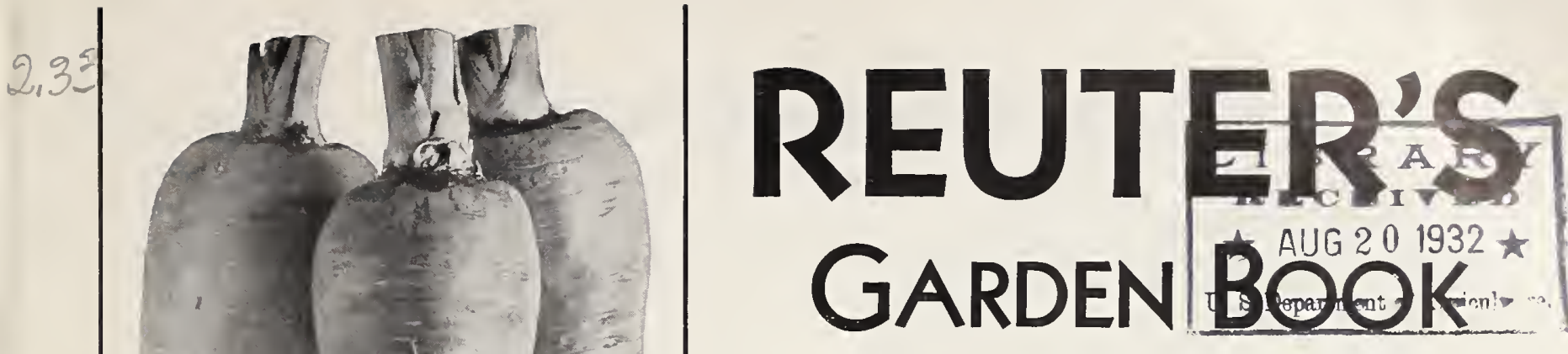

\section{Fall 1932}

农

EUTER'S VEGETABLE SEEDS have enjoyed an enviable reputation among the leading commercial growers and shippers in the South for fifty-two years.

The vegetables illustrated on this cover are the biggest money-making commercial winter crops. Reuter's strains represent the most outstanding achievements in scientific seed-breeding. They warrant the attention of commercial truckers to whom quality, as well as price, is today an important factor.

DANVERS HALF-LONG CARROT The greatest shipping variety in Texas and California

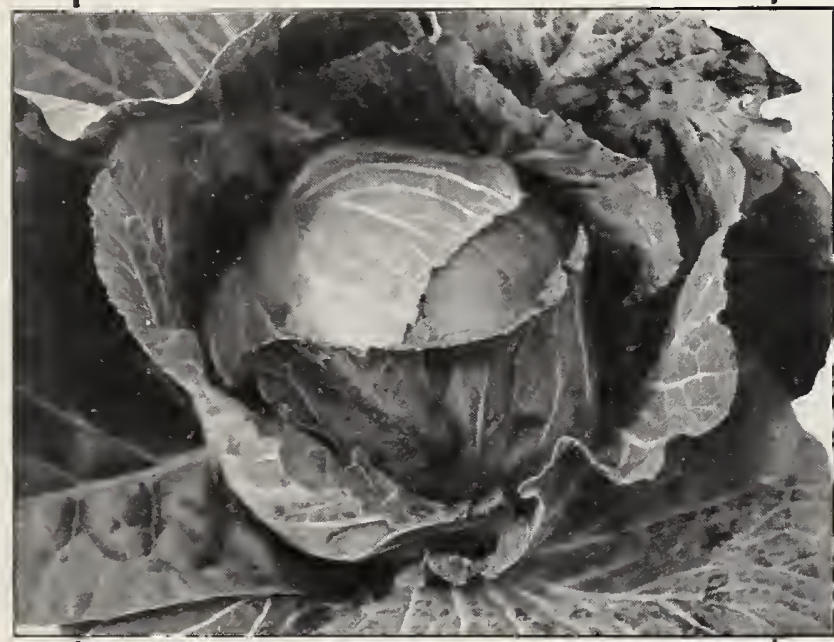

STEIN'S EARLY FLAT DUTCH CABBAGE

Short-stemmed and uniform; pro duces large, very solid heads even under unfavorable conditions.

\section{Plant}

These Money Crops
Danvers Half-Long Carrot. A prime favorite because of its brilliant market appearance. Pkt. 10c; oz. 15c; 1/4lb. 30c; lb. 90c; 5 lbs. $\$ 3.50$, postpaid. Not prepaid: 10 lbs. $\$ 6.00 ; 25$ lbs. $\$ 12.50 ; 100$ lbs. $\$ 45.00$.

Stein's Early Flat Dutch Cabbage. An important shipping variety. It resists disease and is sure to head. Fkt. 10c; 1/2oz. 15c; oz. 25c; 1/4lb. 60c; lb. $\$ 2.00 ; 5$ lbs. $\$ 8.00$, postpaid. Not prepaid: 10 lbs. $\$ 15.00 ; 25$ lbs. $\$ 30.00 ; 50$ lbs. $\$ 50.00$.

Crystal White Wax Bermuda Onion. A profitable, pure white Onion. Pkt. 10c; 1/20z. 15c; oz. 25c;1/4lb. 75 c; lb. $\$ 2.50 ; 5$ lbs. $\$ 11.00$, postpaid. Not prepaid: 10 lbs. $\$ 20.00 ; 25$ lbs. $\$ 45.00 ; 100$ lbs. $\$ 175.00$.

\section{REUTER SEED CO., Inc.} NEW ORLEANS LOUISIANA

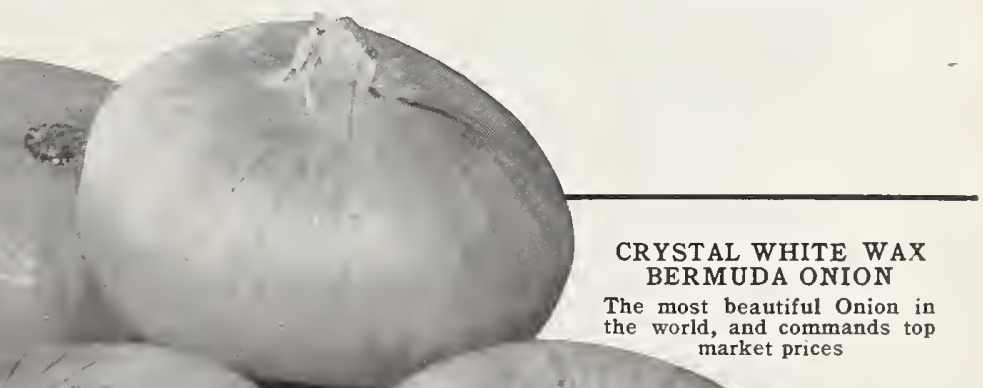




\section{Reuter's Select Vegetable Seeds Produce}

The Vcgetable Seeds offered in this Catalog are of the highest quality. They have been selected carefuIly and show characteristics that mect the most rigid requirements of successful commercial growers and shippers. They are backed by morc than a half century of honcst and conscientious seed service. We challenge comparison. Short seed-supply prompts us to request you to order carly.

\section{BEETS}

58 Detroit Dark Red. The finest and purest strain. Roots arc smooth, globular-shaped, and have small tap-roots. The skin is decp ox-blood-red and the flesh blood-red in color. They are very uniform in shape, color, and quality, and have a medium top-growth. The flavor is sweet. Wc have spared no cxpensc in producing this extra-special strain, and, frankly, we do not know of any better typc on the market today. Recommended highly for canning and bunching purposes. (See illustration.) Pkt. $10 \mathrm{c}$; oz. $15 \mathrm{c} ; 1 / 4 \mathrm{lb} .30 \mathrm{c}$; lb. $90 \mathrm{c} ; 5$ lbs. $\$ 3.50$, postpaid. Not prepaid: 10 lbs. $\$ 5.00 ; 25$ lbs. $\$ 10.00 ; 100$ lbs. $\$ 35.00$.

54 Crosby Egyptian. A distinguished early variety unsurpassed for bunching. The roots are smooth, round, with slightly flattence tops, and very uniform. Skin is deep red and the flesh very dark blood-rcd. The light green tops arc of medium height and of upright habit. We have exercised great care in developing this excellent strain to keep it frec of white centers. Commercial growers who desire the finest stock with richest interior color may plant our seed with confidence. (See illustration on page 7.) Pkt. 10c; oz. $15 \mathrm{c} ; 1 / 4$ lb. 30c; lb. 90c; 5 lbs. $\$ 3.50$, postpaid. Not prepaid: 10 lbs. $\$ 5.00 ; 25$ lbs. $\$ 10.00$; 100 lbs. $\$ 35.00$.

65 Early Wonder. The earliest and most perfectly formed

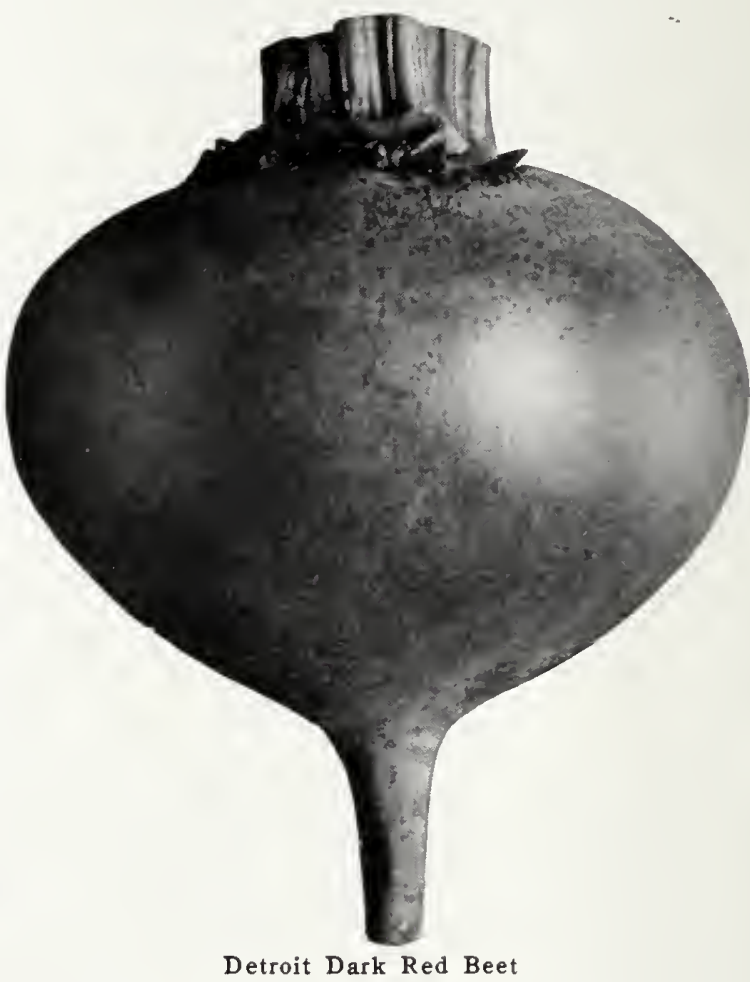

Beet. Its growth is so cven that practically the entire crop may be harvested at one time. Roots are nearly globeshaped, with a moderate top-growth and clean, small tap-roots. The skin is blood-red, and the swcet, crisp flesh deep red with very little white zoning. Pkt. 10c; oz. 15c; 1/4lb. 30c; lb. 90c; 5 lbs. $\$ 3.50$, postpaid. Not prepaid: 10 lbs. $\$ 5.00 ; 25$ lbs. $\$ 10.00 ; 100$ lbs. $\$ 35.00$.

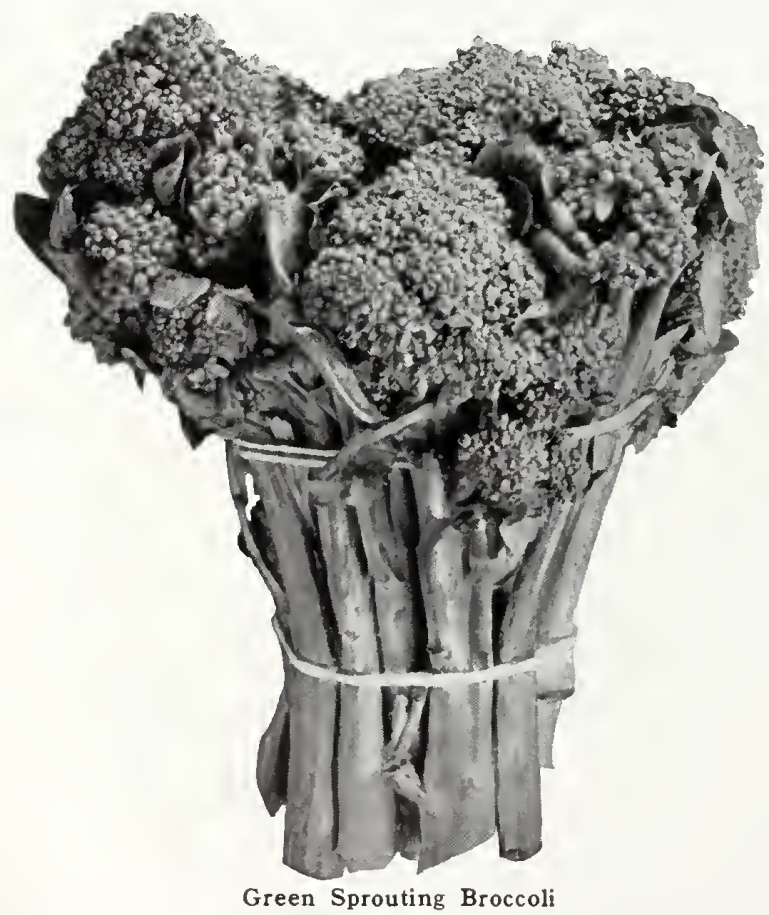

\section{ITALIAN BROCCOLI}

The popularity of this comparativcly new vegetable is sweeping the country as if by storm. Already it has become one of the most important profit-making, wintcr vegctable crops of South Tcxas and Florida. It is really surprising how rapidly it has gained popularity. The delicate and pleasing flavor is distinctly new, yct somcwhat likc cauliflower, and the vegetable contains all the hcalthful qualitics of cauliflower and asparagus.

Sow the sced in plant-beds during July, August, and September and later transplant to the open field. It will mature during the late fall and early winter months. The plants first produce a bluish green head of tightly massed flower-buds which should be cut before blooming. Small bud-heads will then devclop from the axes of the leaves. Thesc arc cut and marketed 2 or 3 to the bunch. First heads ready to cut in about 90 to 100 days. A cool scason is best for its perfect development.

73 Reuter's Green Sprouting. The true imported Italian Calabrese type which is the finest for the South. Commercial growers and shippers are assured of receiving the genuine type of this profitable vesetable delicacy, for we import direct from our private seed-breeder and grower in Italy. (See illustration.) Pkt. 15 c; $1 / 2$ oz. 30 c; oz. 50 c; $1 / 4$ lb. $\$ 1.25$; lb. $\$ 4.00 ; 5$ lbs. $\$ 17.50$, postpaid. Not prepaid: 10 lbs. $\$ 30.00$. 


\section{Better, Big Money-Making, Winter Crops}

\section{CARROTS}

130 Chantenay. Our strain is especially selected for the production of extra-fine, clean, uniform roots with nice-sized bunching tops. The roots are the half-long type, smooth, free of side rootlets, uniform, and a bright orange-red color. They average $51 / 2$ inches in length. The flesh is crisp and tender. Ready to pull in 60 days. (See illustration.) Pkt. 10c; oz. 15c; 1/4lb. 30c; lb. 90c; 5 lbs. $\$ 3.50$, postpaid. Not prepaid: 10 lbs. \$6.00; 25 lbs. $\$ 12.50 ; 100$ lbs. $\$ 45.00$.

136 Coreless Chantenay. An earlier selection of the Chantenay that has been bred and developed to produce a Carrot without the usual pale yellow core. The result is a root with a richer orange color both inside and outside. It is highly recommended. (See illustration on page 8 .) Pkt. $10 \mathrm{c}$; oz. 15c; $1 / 4$ lb. 35c; lb. $\$ 1.00$; 5 lbs. $\$ 4.00$, postpaid. Not prepaid: 10 lbs. $\$ 7.00 ; 25$ lbs. $\$ 15.00$.

129 Danvers Half-Long. Our stock of this variety produces Carrots more uniform in shape and of better color than the strains usually sold. Mature roots are deep, rich orange in color, 7 to 8 inches long, and taper evenly to a blunt end. The flesh is tender, sweet, and crisp. (See illustration on front cover.) Pkt. 10c; oz. 15 c; $1 / 4$ lb. 30c; lb. 90 c; 5 lbs. $\$ 3.50$, postpaid. Not prepaid: 10 lbs. $\$ 6.00 ; 25$ lbs. $\$ 12.50 ; 100$ lbs. $\$ 45.00$.

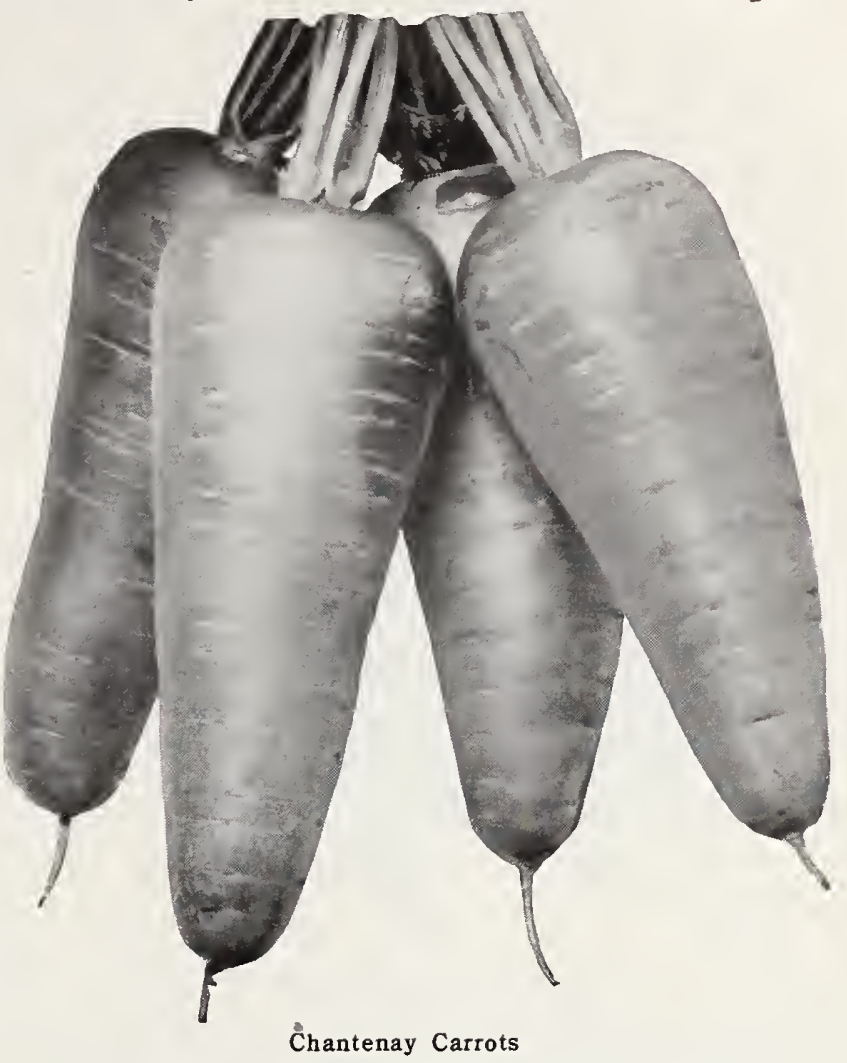

\section{CABBAGE}

86 All-Head Early. A remarkable Cabbage that has won distinction for itself in South Texas because of its high resistance to disease and its ability to produce very solid heads even under adverse weather conditions. It is a heavy yielder of very uniform, deep, flat heads with few outer leaves. They are of medium size (average 4 to 6 pounds) and of extra-fine quality. Plants withstand drought and heat better than most varieties. Our stock of this splendid shipping variety is the finest, and can be depended upon for the desired results. (See illustration.)

Pkt. 10c; $1 / 2$ oz. 15c; oz. 25c;

$1 / 4$ lb. 60 c; lb. $\$ 2.00$;

5 lbs. $\$ 8.00$, postpaid.

Not prepaid: $10 \mathrm{lbs}$.

$\$ 15.00 ; 25$ lbs.

$\$ 30.00 ; 50$ lbs.

$\$ 50.00$.

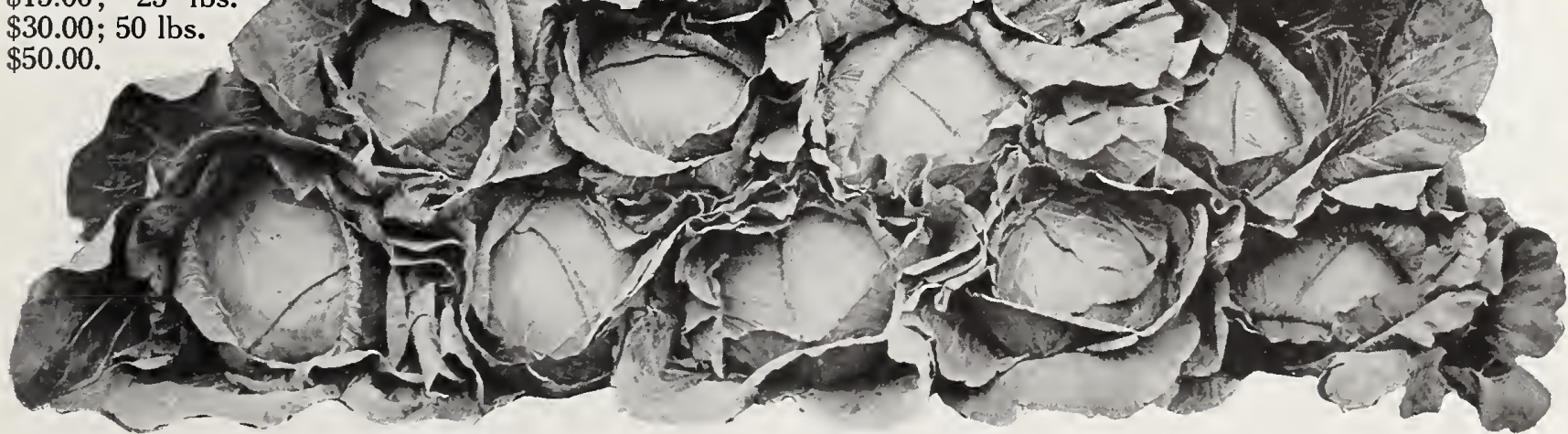

All-Head Early Cabbage grown in South Texas from Reuter's Seeds
92 Stein's Early Flat Dutch. A favorite commercial variety that produces heavily, even under unfavorable conditions. It resists heat and "black leg" and is a most reliable cropper. Plants are shortstemmed, compact, and upright, with few outer leaves. The heads are large, nearly round or somewhat flattened, firm and very solid. (See illustration on front cover.) Pkt. $10 \mathrm{c} ; 1 / 2 \mathrm{oz} .15 \mathrm{c} ;$ oz. $25 \mathrm{c} ; 1 / 4 \mathrm{lb} .60 \mathrm{c} ; \mathrm{lb} . \$ 2.00$; 5 lbs. $\$ 8.00$, postpaid. Not prepaid: 10 lbs. $\$ 15.00 ; 25$ lbs. $\$ 30.00$;

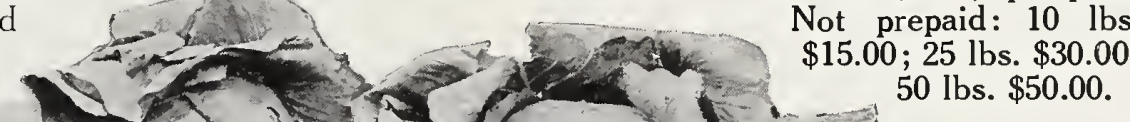




\section{Reuter's Bermuda Onions Are Profitable}

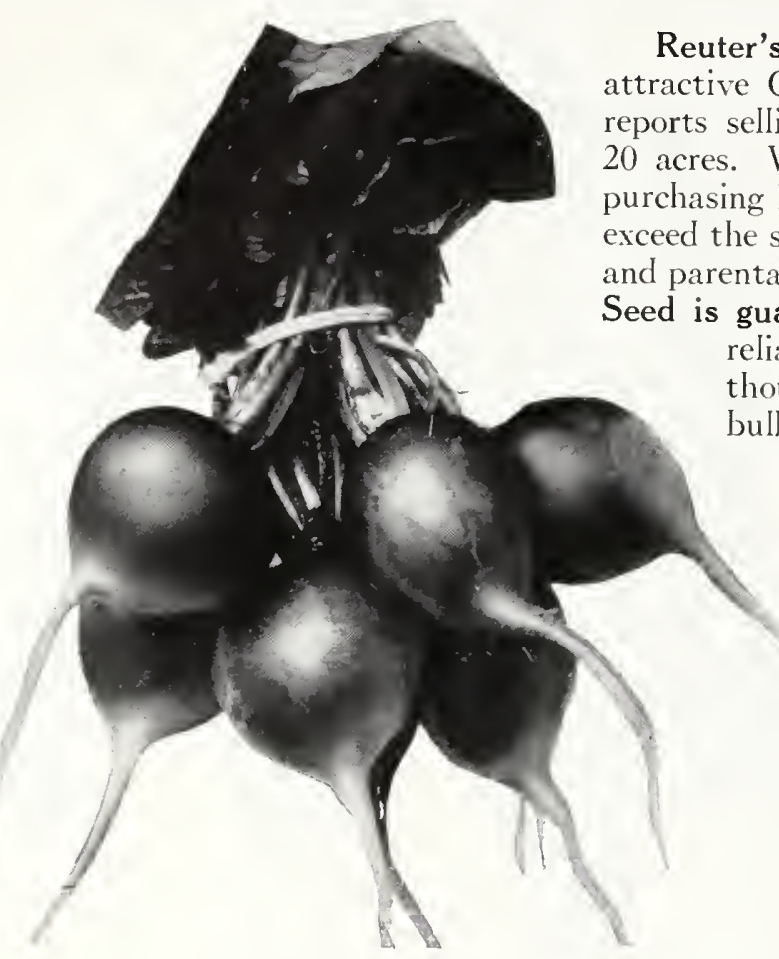

Scarlet Globe Radishes

Reuter's Bermuda Onions are the earliest, mildest flavored, and most Onions in the world! Onc of our South Texas customers 作 supply, and large quantities of inferior seed of uncertain age and parentagc will be imposed upon growcrs. Reuter's Bermuda Onion Seed is guaranteed to be 1932 crop. We annually import from our reliable brceder and grower in the Canary Islands (Teneriffe) thousands of pounds of the finest seed that can be grown. Each bulb producing our seed has bcen carefully stored, hand-sorted and sclected for color and type, and only the cream of the crop is shipped to Reutcr.

363 Yellow Bermuda. The most important of the Bcrmuda varieties. This is the Onion that has made Texas a successful Onion-producing statc. In South Texas, last fall, more than 10,000 acres were planted with Reuter's Yellow Bermuda Onion Seed-the finest seed in the world. The bulbs are medium sized, flat, and of a light straw color. Their flesh is extremely mild and sweet. The highest quality Yellow Bermudas shipped from Texas annually arc produced from Reuter's seed. (Sce illustration.) Pkt. 10c; $1 / 2$ oz. $15 \mathrm{c}$; oz. $25 \mathrm{c} ; 1 / 4$ lb. $75 \mathrm{c}$; lb. $\$ 2.50$; 5 lbs. $\$ 12.00$, postpaid. Not prepaid: 10 lbs. $\$ 22.00$; 25 lbs. $\$ 52.50$; 100 lbs. $\$ 200.00$.

366 Crystal White Wax Bermuda. The mildest and most attractive Onion in the world. Our truc-type stock produces bulbs that are vcry flat and medium-large in size. The thin skin is pure white and crystalline-the flesh white and waxy in texturc. (IIlustration on front cover shows specimens grown from seed planted in Octobcr.) Pkt. 10c; 1/20z. 15c; oz. 25c; $1 / 4$ lb. 75 c; lb. $\$ 2.50 ; 5$ lbs. $\$ 11.00$, postpaid. Not prepaid: 10 lbs. $\$ 20.00 ; 25$ lbs. $\$ 45.00 ; 100$ lbs. $\$ 175.00$.

\section{Riverside Sweet Spanish Onion}

373 A valuable new Onion of the Spanish Valencia type popular because of its extremely largc size, appearance, and flavor. The globc-shapcd, light yellow bulbs, when maturc, often measure 4 to $6 \frac{1}{2}$ inches in diameter and weigh 2 pounds. Its sparkling white flesh is mild and very sweet. An excellent shipping variety as the bulbs are harder, firmer, and keep better than Bermudas. Pkt. 10 c; $1 / 2$ oz. 15 c; oz. 25 c; $1 / 4$ lb. 75 c; lb. $\$ 2.50 ; 5$ lbs. $\$ 11.00$, postpaid. Not prepaid: 10 lbs. $\$ 20.00 ; 25$ lbs. $\$ 45.00 ; 100$ lbs. $\$ 175.00$.

\section{RADISH}

469 Scarlet Globe. A superb, re-selected strain. Its roots are perfcctly oval and have a thin tap-root. The skin is brilliant scarlet, and the flesh is pure white, crisp, and delightfully flavored. Its mediumsized tops are excellent for bunching. Grows quickly and evenly, maturing in about 3 weeks, under normal conditions. Pkt. 10c; oz. $15 \mathrm{c} ; 1 / 4 \mathrm{lb} .25 \mathrm{c} ; \mathrm{lb} .75 \mathrm{c}$; 5 lbs. $\$ 3.00$, postpaid. Not prepaid: 10 lbs. $\$ 5.00$; 25 lbs. $\$ 10.00 ; 100$ lbs. $\$ 35.00$.

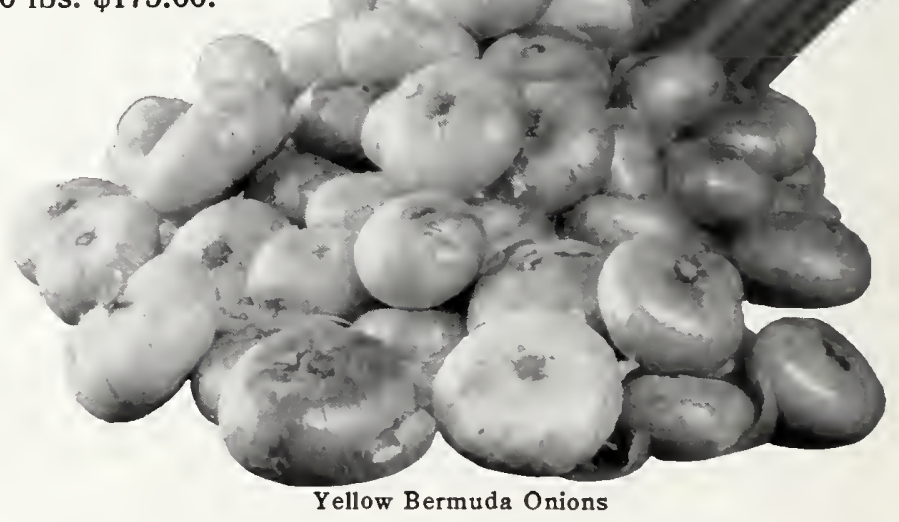




\section{Reuter's Superb First-Quality Spinach}

Our famous Savoy-leaved types are the result of years of careful and painstaking selection. The most modern scientific breeding methods have been employed in developing a truly superior product. We offer pure bisexual varieties produced from single plant selections. To maintain these perfect Savoy-leaved types thorough and repeated roguing of the seed crops is necessary. Producing seed of these distinguished strains is a more expensive process than is required in the case of the ordinary Bloomsdale types, which are generally grown as a regular farm-crop. Therefore, our high-bred Spinach seed-stocks, even at a slightly higher cost, are sure to yield better returns.

502 Bloomsdale Savoy. Extra Dark Green. A new, beautiful, better, and darker colored strain. The plants, which are quite early in maturing, have a fresh appearance for a longer time after being cut, because of the deep, glossy green color. Its large, fleshy leaves are deeply crumpled and remain in prime condition longer than those of the old Savoy-leaved. We are highly impressed with this attractive and outstanding improvement. (See illustration.) Pkt. 10c; oz. 15 c; $1 / 4$ lb. 20c; lb. 50 c; 5 lbs. $\$ 2.00$, postpaid. Not prepaid: 10 lbs. $\$ 3.00 ; 25$ lbs. $\$ 5.00 ; 100$ lbs. $\$ 15.00$.

507 Long-standing Bloomsdale. A new strain of outstanding merit that has already become a favorite with commercial growers because of its splendid performance. Its attractive, deep, glossy green leaves are intensely crumpled and very uniform. The plants are almost as early and quick-growing as the Bloomsdale, but they will stand in a marketable condition 10 to 14 days longer before bolting to seed, which is a valuable asset to the commercial grower and shipper. Highly recommended for marketing in the late spring, because it is seldom seriously injured by the first warm days which often ruin completely the early-maturing
Bloomsdale. Pkt. 10c; oz. 15c; 1/4lb. 20c;
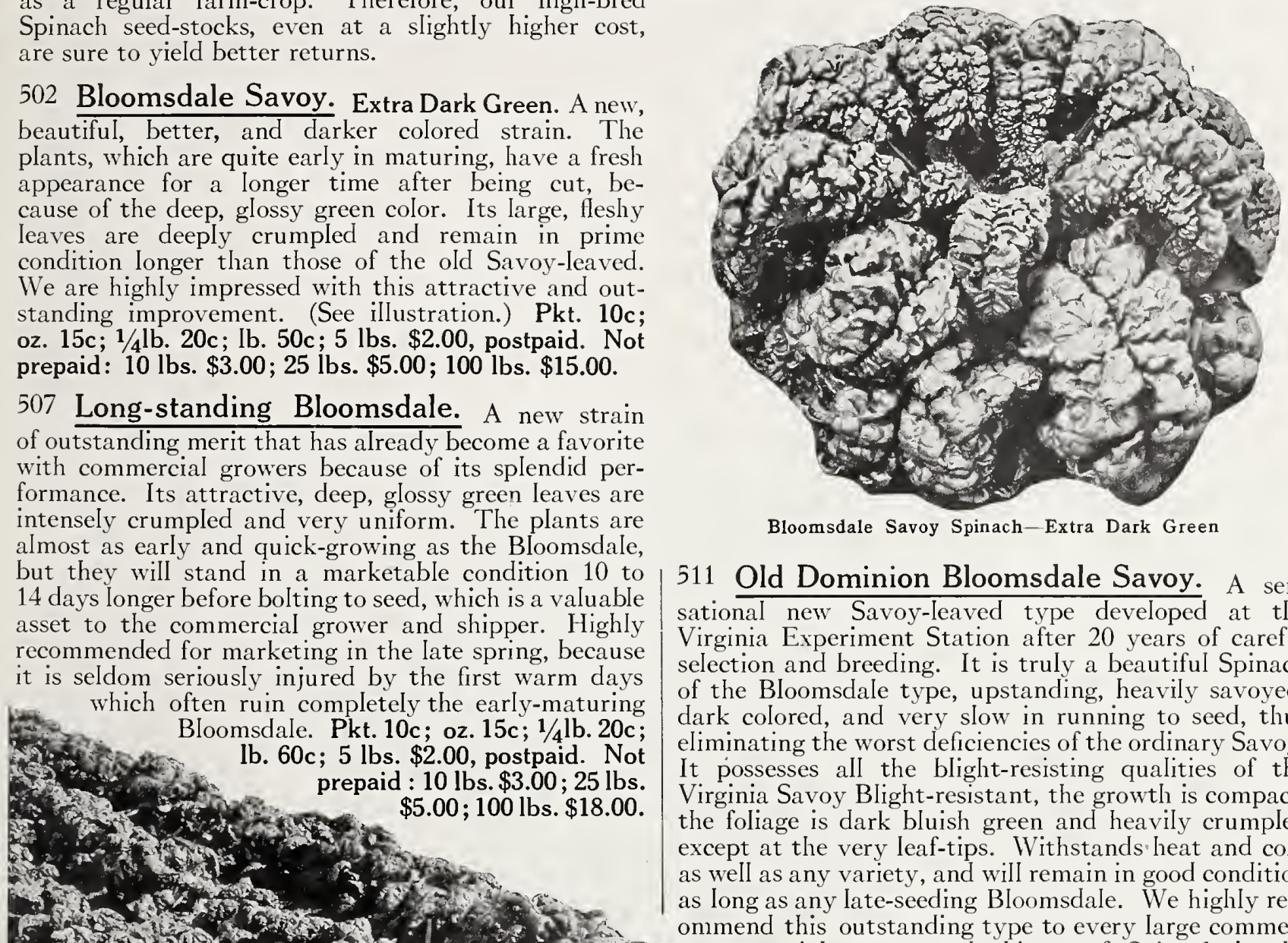

511 Old Dominion Bloomsdale Savoy. A sensational new Savoy-leaved type developed at the Virginia Experiment Station after 20 years of careful selection and breeding. It is truly a beautiful Spinach of the Bloomsdale type, upstanding, heavily savoyed, dark colored, and very slow in running to seed, thus eliminating the worst deficiencies of the ordinary Savoy. It possesses all the blight-resisting qualities of the Virginia Savoy Blight-resistant, the growth is compact, the foliage is dark bluish green and heavily crumpled except at the very leaf-tips. Withstands heat and cold as well as any variety, and will remain in good condition as long as any late-seeding Bloomsdale. We highly recommend this outstanding type to every large commer-

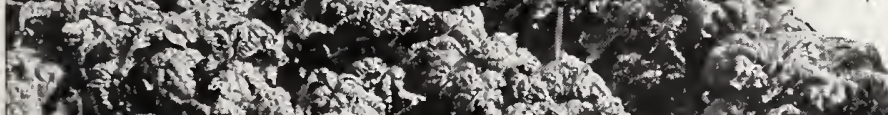
cial grower and shipper of Spinach in the

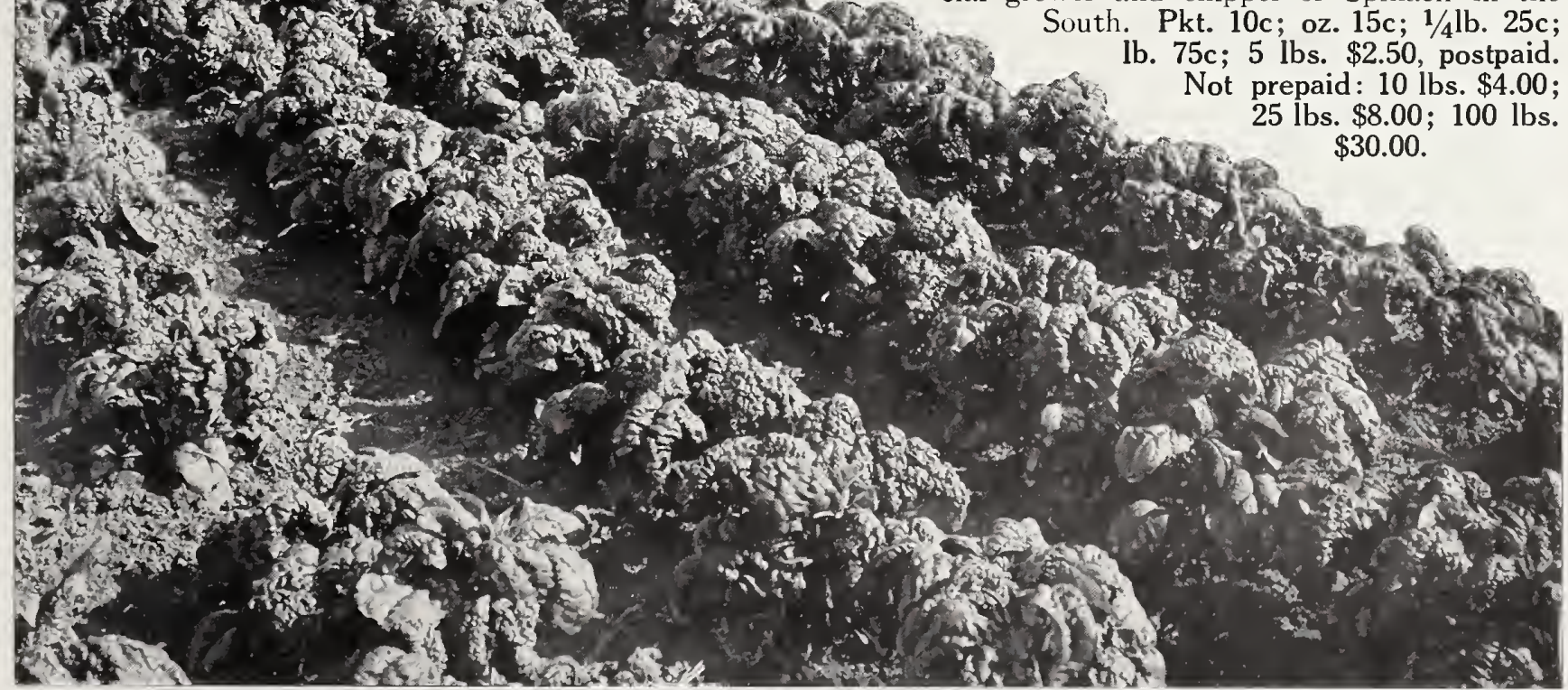

Old Dominion Bloomsdale Savoy Spinach 


\section{General Vegetable List}

Reuter's Vegetable Seeds are the result of years of careful the most modern and best-cquipped seed-testing laboratory in seed-breeding. Extensive trials of all our Vegetable Seeds are the South. No cffort or cxpense is spared in furnishing our conducted on our 60-acre experiment farm for the purpose of thousands of loyal and satisfied customers with the highest determining their purity and adaptability. We also maintain quality Vegetable Seeds.

\section{BEANS Green-Pod Bush}

16 Asgrow Valentine. A perfect, stringless Black Valentine Bean which retains the hardiness, large yicld, and splendid general qualities of the original varicty. For table quality it is unsurpasscd. A good shipper. Pkt. 10c; 1/2lb. 25c; lb. 40c; 2 lbs. (pk.) $\$ 2.75$; $60 \mathrm{lbs}$. (bus.) $\$ 10.00$; $100 \mathrm{lbs}$. $\$ 16.00$.

10 Black Valentine. Ready for market in 42 days. Earliness, productivity, heat-resisting qualities, and appearance have popularized this varicty among southern commereial truckcrs. The pods are round, slender, straight, about 6 inchc lb. $35 \mathrm{c} ; 2 \mathrm{lbs}$. $60 \mathrm{e} ; 5 \mathrm{lbs}$. $\$ 1.25$, postpaid. Not prepaid: 15 lbs. (pk.) \$2.00; 60 lbs. (bus.) $\$ 7.00$

11 Bountiful. Ready in 46 days. The most productive and best flat, green-podded Bush Bean. The plants are vigorous, disease-resistant, and 7 inches long. The flavor is cxcellent. Pkt. $10 \mathrm{c}$ $1 / 2 \mathrm{Lb}$. 20c; $1 \mathrm{lb} .35 \mathrm{c} ; 2 \mathrm{lbs} .65 \mathrm{c} ; 5 \mathrm{llss} . \$ 1.40$, post paid Not prepaid: 15 lbs.

14 Giant Stringless Green-Pod. Ready in less, meaty, round, brittlc, and a medium green color. They grow about 6 inches long and are quite straight. (Sce illustration.) Pkt. 10c; 1, lb. 20c prepaid: 15 lbs. (pk.) $\$ 2.10$; 60 lbs. (bus.) $\$ 7.50$ $100 \mathrm{lbs}$. $\$ 1200$.

13 Longfellow. Ready in 48 days. Moderately eary, pong long, sender, round and stringless whe young. Pkt. 10c; 2 lb. $20 \mathrm{c} ; \mathrm{lb}$. $35 \mathrm{c} ; 2 \mathrm{lbs} .65 \mathrm{c} ; 5 \mathrm{lbs}$. 60 lbs. (bus.) $\$ 7.50 ; 100$ lbs. $\$ 12.00$.

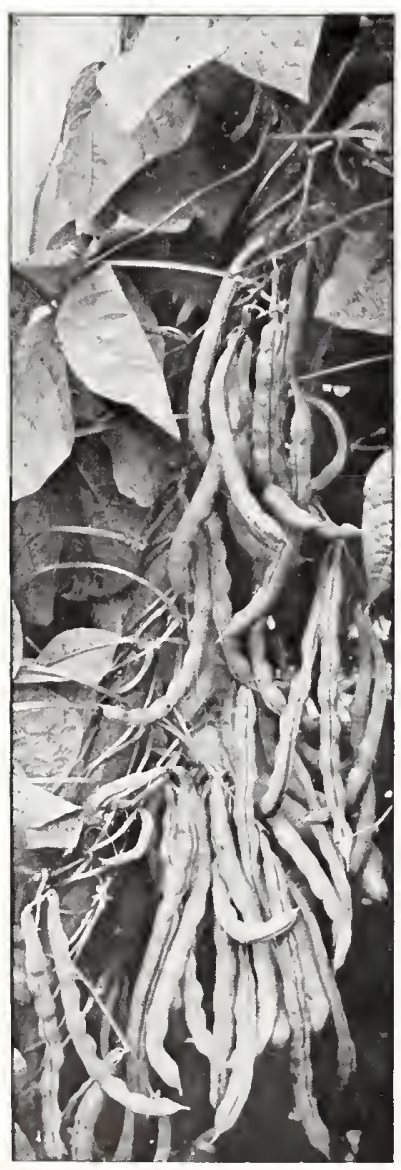

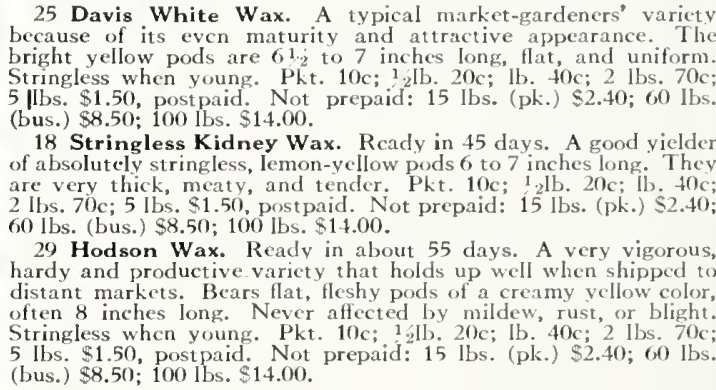

\section{BEANS, Pole or Climbing}

47 Reuter's Ideal Market. Our own exclusive An excellent table variety that is ready in 50 days and extensively
planted by truckers for shipping to northern markets. More hardy, and outyiclds other green-podded Pole Beans; fulty 2 weeks earlic than Kentucky Wonder; only a few days behind Bush Beat planted at the same timc. Pods are 51,2 to 6 inches long, perfectly

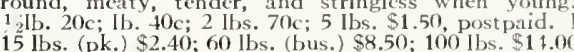

33 McCaslan. A heavy viclder of large, rich deep green pods 8 to 10 inches long, slightly flat, stringless, meat and of ap ing flavor. Pkt. 10c; 1 ; llb. 20c; lb. 40c; 2 lbs. 70c; 5 llss. $\$ 1.50$, post paid. Not
100 lbs. $\$ 14.00$.

34 Kentucky Wonder. Ready in 60 days. The most popular of grcen-podded Pole Beans. Bears a bountiful crop of fleshy pod 8 to 10 inches long that are nearly round, plump, and almos stringless. (See illustration.) Pkt. 10c; $12 \mathrm{~b} .20 \mathrm{c} ; 1 \mathrm{~b}, 35 \mathrm{c} ; 2 \mathrm{lbs} .65 \mathrm{c}$ 5 Ibs. $\$ 1.40$, postpaid. Not
(bus. $\$ 7.50^{\circ}, 100$ lbs, $\$ 12.00$

36 Genuine Cornfield. Splendid for planting in eorn. The pods are 6 to 7 inches long, completely rounded, very fleshy an postpaid. Not prepaid: 15 lbs. (pk.) \$2.60; 60 lbs. (bus.) \$9.50; 100 lbs. $\$ 15.00$

32 White Creaseback. Very hardy, early, and productive The pods are 5 to 6 inches long, well rounded, crease-backed, al mos straight, and nearly stringless. Pkt. $10 \mathrm{c} ; 1$ il $\mathrm{lb} .20 \mathrm{c} ; 1 \mathrm{~b} .40 \mathrm{c} ; 2 \mathrm{lbs}$ 60 Ibs. (bus.) $\$ 8.50 ; 100 \mathrm{lbs}$. $\$ 1.00$

49 White Cornfield. An early, green-podded variety. The vines are vigorous and bear 5 - to 6 -incl pods, fully rounded, tender

Kentucky Wonder Beans postpaid. Not prepaid: 15 lbs. (pk.) \$3.50; 60 lbs. (bus.) $\$ 13.50$;

\section{ed}

46 Burpee's Stringless Green-Pod. Ready to pick in 45 days. An . They are an attractive,

100 lbs. $\$ 12.00$. The pods, which have slight strings, are $4 \frac{1}{2}$ to 5 inches long, very fleshy.

Measure. Ready in about 42 days. A finc, strictly stringles (pk. $\$ 2.40 ; 60$ lbs. (bus.) $\$ 8.50 ; 100$ Ibs are flat, bright green in liavored. Pkt. 10c; 2 lb. $20 \mathrm{c}$; Ib. $40 \mathrm{c} ; 2$ Ibs. $70 \mathrm{c} ; 5$ lbs. $\$ 1.50$, post paid. BEANS, Wax-Podded Bush

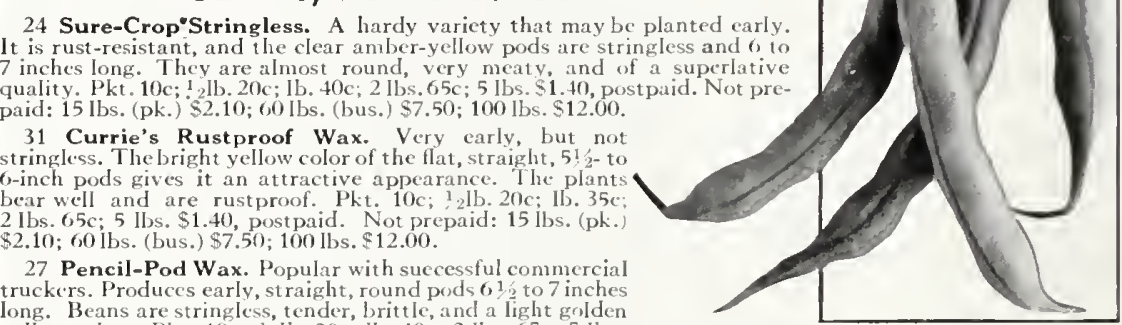

Giant Stringless Green-Pod Beans

BEANS, Bush Lima

38 Henderson Bush Lima. The "Baby Lima." Ready in 60 days. Early, hardy vines produce pods tb. 20c; Ih. 35c; 2 Ibs. 65 c; $5 \mathrm{lbs}$. $\$ 1.40$, post paid (pk.) $\$ 2.10$; 60 ibs. (bus. $\$ 7.50 ; 100 \mathrm{lbs}, \$ 12.00$

39 Jackson Wonder Bush Lima. Prolific mediun-sized pods containing 3 to 5 Beans. Pkt. $10 \mathrm{c} ; 1 / 2 \mathrm{lb}$. 25c; Ib. 40c; 2 Ibs. 70c; 5 lbs. $\$ 1.50$. post (bus.) $\$ 9.50$; 100 Ibs. $\$ 15.00$

$\$ 1$ Fordhook Bush Lima. A big seller. Pods 152 to 5 inches long contaning 4 or 5 Beans. Pkt. (5 las. (p.) \$3.50; 60 lbs. 48 Burpee Improved Bush Lima. Ready in 65 days. Pods are 5 to 6 inches long and contain 4 or 5 Bcans of good flavor. Pkt. $15 \mathrm{c} ; 1 / 21 \mathrm{lb} .25 \mathrm{c}$;
Ib. $45 \mathrm{c} ; 2$ lbs. $80 \mathrm{c} ; 5$ Ilss. $\$ 1.75$, postpaid. Not pre paid: 15 Ibs. (pk.) \$3.50; 60 lbs. (bus.) \$13.50;

\section{BEANS, Pole Lima}

12 Carolina or Sieva. The earliest variety. The tender pods are $31_{2}$ inches long and a rich 2 Ibs. $70 \mathrm{c}$ : 5 Ilbs. $\$ 1.50$ postpaid. Not. $20 \mathrm{c}$; 15 . (pk.) $\$ 2.40 ; 60$ Ibs. (bus.) $\$ 8.50$; 100 Ibs. $\$ 14.00$.

(pk Florida Butter Pole Lima. A mediumsized Bcan of good quality that resists the Bean bectle. Pht. 10c; 12 lb. 20c; lb. 40c; 2 lbs. $70 \mathrm{c}$
5 lbs. $\$ 1.50$, postpaid. Not prepaid: 15 lbs. (pk. \$2.40. 60 lbs, (bus, $\$ 8.50 ; 100$ lbs. $\$ 14$;

19 King of the Garden. The nyediun oreen pods are 5 to 6 inches long and contain 4 or 5 large, white Beans. Pkt. $10 \mathrm{c} ;{ }^{1}{ }_{2} \mathrm{lb} .25 \mathrm{c} ; \mathrm{Ib} .40 \mathrm{c} ; 2 \mathrm{lbs} .75 \mathrm{c}$ 5 liss. $\$ 1.50$, postpaid. Not prepard: 15 lbs. (phi, 20 Challenger or Potato Lima. Prolifie and early. Pods average 3 to 4 inches long; Beans well 5 lbs. $\$ 1.75$, postpaid. Not prepaid: 15 lbs. (ph.)

BEANS, Broad, Horse or Fava

52 Planted throughout the South for shipping north when green. Will stand temperature of only 15 degrees without being seriously injired. Pht. 10c; Not prepsid: 15
100 lbs. $\$ 14.00$ 


\section{Successful Commercial Gardeners Recommend Reuter's Seeds}

\section{BEETS}

54 Crosby Egyptian. A very early Beet with smooth, round roots, slightly Cor the fis growth. We have exercised great care in keeping our strain free of white centers. Commercial growers of fancy stock will find that this variety meets every requirement. (See illustration.) Pkt. 10c; oz. 15c; 1/.1 Ib. 30c; Ib. 90c; 5 Ibs. $\$ 3.50$, postpaid. Not prepaid: 10 Ibs. $\$ 5.00 ; 25$ lbs. $\$ 10.00 ; 100$ Ibs. $\$ 35.00$.

58 Detroit Dark Red. An unusual outstanding type that is rccommended for market- and home-gardens. Skin of the globe-shaped roots is ox-blood-red and the flesh blood-red. They are uniform in shape, color, and quality, and have a small top-growth Sweet flavor makcs it desirable for canning. Pkt $10 \mathrm{c}$ oz. $15 \mathrm{c}$; $1 \mathrm{flb}$. $30 \mathrm{c}$; $[\mathrm{b}$. $90 \mathrm{c} ; 5 \mathrm{lbs}$. $\$ 3.50$, postpaid. Not prepaid: $10 \mathrm{lbs}$. $\$ 5.00$ 25 lbs. $\$ 10.00 ; 100$ lbs. $\$ 35.00$.

65 Early Wonder. The ideal market Beet. It is the earliest variety, its shape is perfect, and the growth is so even that practically the entire crop may be harvested at one time. The roots are nearly globe-shaped, with blood-red sckin and decp red llesh that is sweet and crisp and shows very litte white zoning

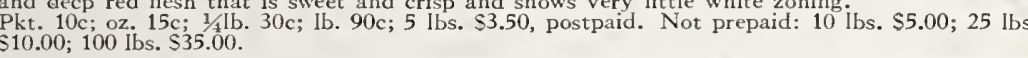

66 Reuter's Fireball. A Beet of unexcelled quality. It is an early variety with a fine globe shape. Skin and flesh are rich deep red in color. The tap-root is small and the top-growth slender Even when allowed to mature, the roots maintain their high quality. We heartily recommend this

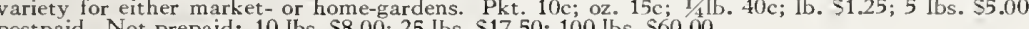

55 Early Eclipse. Extra early. The bright, deep red-skinned roots are uniformly round. It (a) $\$ 3.50$, postpaid. Not prepaid: $10 \mathrm{lbs}$. $\$ 5.00$.

57 Edmand's Blood Turnip. A desirable second-early market variety. It is nearly round turnip-shaped, of good size and appearance. Skin is dark red, and the tendcr, sweet flesh is purplish red with little zoning. It is a

63 Half-Long Blood. A distinct, second-early Beet. The deep red roots are a half-long type somewhat pear-shaped and smooth. The flesh is fine grained, free from hard fiber, and has a sweet flavor. An excellent slicing variety. Pkt. 10c; oz. 15c; 1 Ib. $30 \mathrm{c}$; Ib. $90 \mathrm{c} ; 5$ lbs. $\$ 3.50$, postpaid. Not prepaid: 10 Ibs. $\$ 5.00$.

\section{MANGEL-WURZELS}

61 Mammoth Long Red. The most popular sort. Its smooth, clean, very uniform roots are often 2 feet long. Skin is bright red and the Hesh is white tinted rose. Easily harvested as roots grow one-half to two-thirds out of the ground. The me oz. $15 \mathrm{c} ; 1 / \mathrm{Ib}$. $20 \mathrm{c} ; \mathrm{lb}$. $50 \mathrm{c} ; 5 \mathrm{lbs}$. $\$ 2.00$, postpaid. Not prepaid: 10 lbs. $\$ 3.50 ; 25$ Ibs. $\$ 8.00 ; 100$ lbs.

69 Red Giant Eckendorf. The very large, broad, round-topped, red roots are especially desirable for dairy feeding. Very easily harvested Pkt. 10c; oz. 15c; 1//1b. 20c; Ib. 50c; 5 lbs. $\$ 2.00$ postpaid. Not prepaid: 10 Ibs. $\$ 3.50 ; 25$ Ibs. $\$ 8.00$; CORN SALAD

205 Doucet. A hardy, quick-growing plant that is a good substitute for lettuce or spinach. Matures in 6 to 8 weeks.
50 ; Ib. $\$ 1.50$, postpaid.

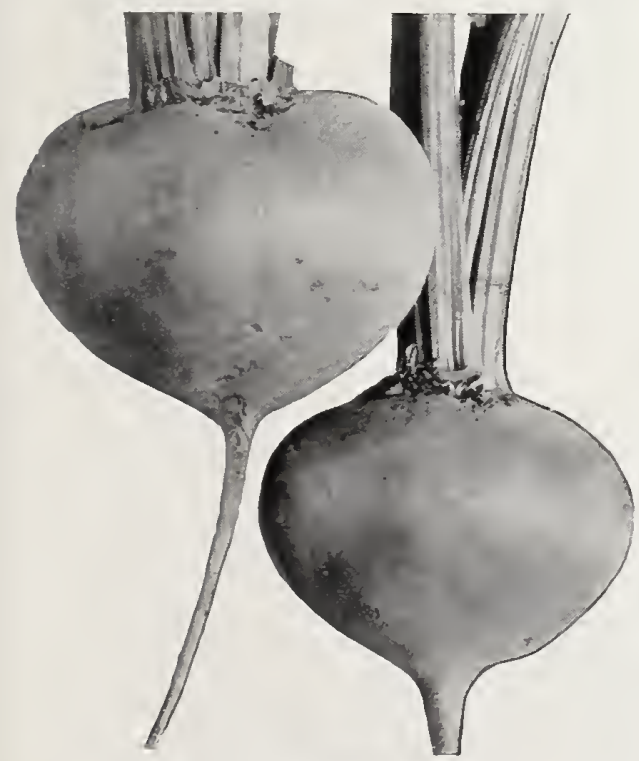

Crosby Egyptian Beets

\section{SUGAR BEET}

62 Klein Wanzleben. A productive variety, high in sugar content and valuable for stock-feeding Its roots are straight, even, conical shaped, and large. May be grown with as little as 5 inches oz. $15 \mathrm{c} ; 1 / 4 \mathrm{lb}$. $20 \mathrm{c}$; Ib. $60 \mathrm{c} ; 5$ lbs. $\$ 2.50$, postpaid.

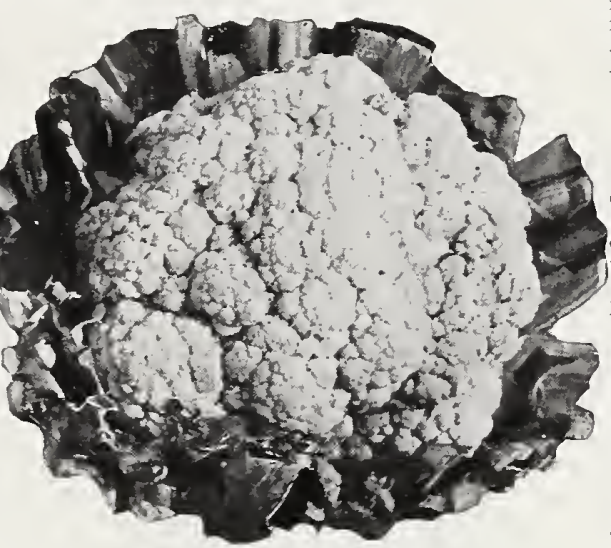

White Wonder Cauliflower

\section{BRUSSELS SPROUTS}

\section{Long Island Improved. The best market} variety of this unique member of the Cabbage family. Plants are of dwarf habit, compact and IJuality. $\$ 2.00 ; 5$ lbs. $\$ 9.00$, $20 z$. $15 c$

\section{BROCCOLI}

73 Green Sprouting. The true imported 73 Green South and quite distinct from the white heading Broccoli. Plant grows rapidly and in about 90 days
produces a large central cluster of tightly closed flower-buds which should be cut before blooming Small bud-heads will then develop from the leaves axes and these should be cut and marketed 2 or 3 reliable seed-breeder in Italy, commercial growers and shippers are assured of receiving genuine seed of this profitable vegetable delicacy. (See $1 / 1 \mathrm{lb}$. $\$ 1.25$; Ib. $\$ 4.00 ; 5 \mathrm{lbs}$. $\$ 17.50$, postpaid. Not prepaid: $10 \mathrm{Ibs}$. $\$ 30.00$.

\section{CARDOON}

169 A large, fleshy-leaved plant used as a winter Pke main stalks are blanched in the same manner
Pkt. 10c; oz. 30c; $1 / 4 \mathrm{~L}$. \$1.00; Ib. \$3.50, postpaid.

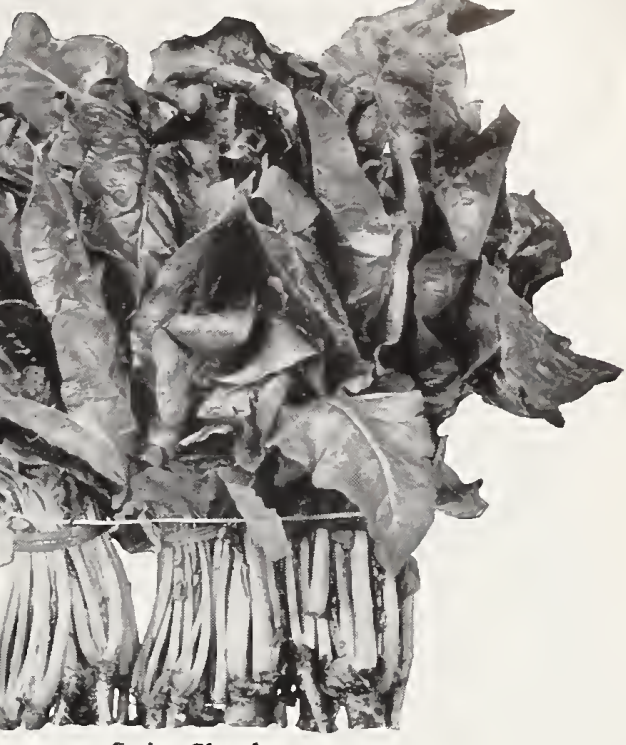

Swiss Chard

\section{SWISS CHARD}

68 Reuter's Spinach-leaved. The leaves are almost identical to smooth-leaved spinach and are equally dark green in color. The light green midribs is its capacity to produce growth during the summer months when spinach will not. Market gardeners find a ready sale for this commodity in the local markets during the late summer and early fall 5 lbs. $\$ 4.00$, postpaid. Not prepaid: 10 Ibs. $\$ 7.00$; 25 lbs. $\$ 15.00$.

\section{CAULIFLOWER}

\section{White Wonder. The} too shortleaved. Maturity is uniform. The spotless purity strains. (See illustration.) Pkt. $35 \mathrm{c} ; 1 / \mathrm{oz} .75 \mathrm{c}$;
$1 / 2 \mathrm{oz}$. \$1.25; oz. $\$ 2.00 ; 1 / 4 \mathrm{lb}$. $\$ 7.00 ; \mathrm{Ib} . \$ 25.00$, ostpaid.

144 Early Snowball. Matures 52 days after the favorite of market gardeners. Its compact heads that are 9 to 10 inches in diameter, firm and tender. Pkt. 20c; $1 / 4 \mathrm{oz}$. 50c; $1 / 20 z$.

145 Large Algiers. A late sort whose robust, upright plants produce grant-sized, creamy white The outer leaves are large and so protcct the head that it withstands frosts that ruin most other Pkt. 15c; $1 / 4 \mathrm{oz} .25 \mathrm{c} ; 1 / 2 \mathrm{Oz} .40 \mathrm{c} ;$ oz. $75 \mathrm{c} ; 1 / 2 \mathrm{Ib} . \$ 2.00$ Ib. $\$ 7.00$, postpaid.

\section{CRESS}

297 Curled. Crisp, tender, and pungently postpaid. 286 Water Cress. I lighly esteemed. It must be grown along moist banks or in tubs of water covered . $15 \mathrm{c} ; 1 / 2 \mathrm{Oz}$. $40 \mathrm{c} ; 0 z .65 \mathrm{c} ; 1 / 4 \mathrm{lb} . \$ 1.75$. CHICORY

6 Asparagus Chicory. A favorite with Italians. (hes

\section{CHERVIL}

173 Resembles parsley, but is considered to have superior havor. Sced slow to germinate. Pkt.

Reuter's Winter Garden Book (Ready October 1)

A garden guide featuring a full list of winterand spring-blooming bulbs and nursery stock. 


\section{Reuter's Seeds Are Laboratory and Garden Tested}

\section{CABBAGE}

84 Early Jersey Wakefield. This Cabbage. Crop ean be cut within 60 days after transplanting. The compact, dwarf plants are very hardy and will withstand eold and other adverse conditions. Its conica $1 / \mathrm{lb}$. $60 \mathrm{e}$; Ib. $\$ 2.00 ; 5 \mathrm{Ibs}$. $\$ 8.00$, post paid. Not prepaid: $10 \mathrm{lbs}$. $\$ 15.00 ; 25$ Ibs. $\$ 30.00$; 102 Golden Acre. An earlier selection of the popular Copenhagen Market variety. It weigh 3 to 4 pounds, are uniform in size, shape, and time of maturity, and of very good quality. Plant has few outer leaves, which permits close planting. Pkt. $10 \mathrm{c} ; 1,2 \mathrm{Oz}$. $20 \mathrm{c}$ oz. $35 \mathrm{c}$; I Ib. $\$ 1.00$; Ib. $\$ 3.50$; 5 Ibs. $\$ 15.00$, postpaid. Not prepaid: $10 \mathrm{lbs}$. $\$ 27.50$.
89 Copenhagen Market. The earliest, large, round-headed Cabbage yet introduced, and a variety that is very popular with market gardeners. Heads, which often are compact, vigorous, and produce only a few outer leaves of upright growth. Our

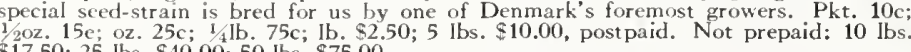
90 Disease-resistant Copenhagen Market. This remarkably early and true-to-type strain has been bred to effectively resist the disease "yellows" which has been destroyin

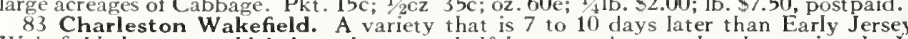
Wakefield, but one which is at least one-half larger and somewhat less pointed. It bears a very solid, blunt-pointed head that is broad at the base, uniform in size, and shippers. (See illustration.) Pkt. $10 \mathrm{c} ; 1 / 20 \mathrm{oz} .15 \mathrm{c} ; \mathrm{oz} .25 \mathrm{c} ; 1 / 1 \mathrm{lb} .60 \mathrm{c} ; \mathrm{Ib} . \$ 2.00 ; 5 \mathrm{Ibs} . \$ 8.00$, post paid. Not prepaid: $10 \mathrm{lbs} . \$ 15.00 ; 25 \mathrm{lbs}$. $\$ 30.00 ; 50 \mathrm{lbs} . \$ 50.00$. 92 Stein's Early Flat Dutch. Desirable sort for commercial purposes because of its ability to produce a crop under unfavorable conditions. Plants are short-stemmed,
compact, and upright, with few outer leaves, which permits close planting. The heads compact, and upright, with few outer leaves, which permits close planting. The heads
arc nearly round or somewhat flattened, close, firm, and very solid. Average wcight is 12 to 15 pounds. Highly resistant to eertain dis-

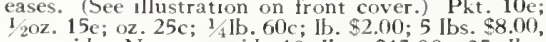
postpaid. Not prepaid: 10 lbs. $\$ 15.00 ; 25$ Ibs.

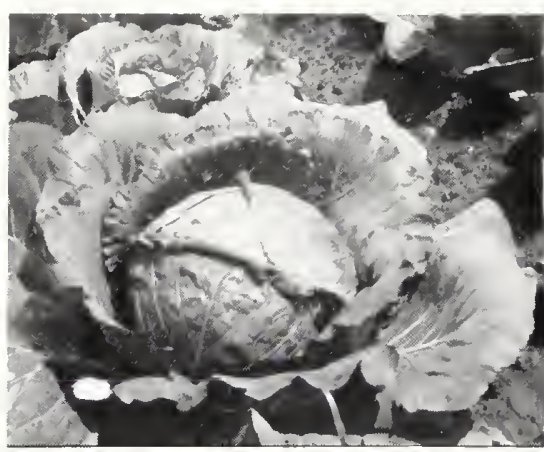

Glory of Enkhuizen Cabbage

97 Glory of Enkhuizen. Matures in 70 to 75 days. A short-stemmed, round-headed sort that is widely cultivated by shippers in South Texas. The
dark grcen heads grow large, very solid, nearly round, and have an excellent flavor. Larger and
later than Copenhagcn Market. (See illustration.)
Pkt. 10c; 1 20z. 15c; oz. 25c; 1 Ib. 60c: Ib. $\$ 2.00$

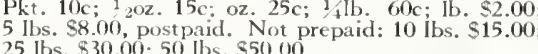
25 lbs. $\$ 10.00 ; 50$ Garly. Is especially popular with growers and shippers in Texas because it is showing even in size, solicl, flat, but very deep. Plants are $A$ heavy yiclder that stands drought and hea

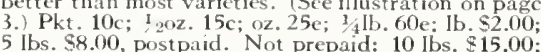
5 Ibs. $\$ 8.00$, postpaid. Not prepaid: 10 Ibs. $\$ 15.00$ 91 Succession. A surc-licading sort, popular with local market gardeners. Plants are strong and
vigorous and produce flat, firm, very solid heads usually weighing 8 to 10 prunds. They are uniform
in shape and time of maturity. Pkt. 10c; $120 z .15 \mathrm{e}$ oz. $25 \mathrm{e} ; 1_{4} \mathrm{Ib} .60 \mathrm{c}$; Ib. $\$ 2.00 ; 5 \mathrm{Ibs}$. $\$ 8.00$, post paid. No 93 Surehead. Will always head. This is an exceptionally fine main-crop type of Flat Dutch
Cabbage. The uniforn-sized heads are large,
usually weighing 10 to 15 pounds, round, somewhat "lsually weighing 10 to 15 pounds, round, Somewha paid. Not prepaid: 10 Ibs. $\$ 15.00 ; 25$ lbs. $\$ 30.00$ 50 lbs. $\$ 50.00$. The 85 Volga. The moderately spreading. They are naturally "yellows" resistant. The Iarre, round heads measure 10 inches in diameter and weigh about 10 pounds 25c; 1/LIb. 60c; 1b. $\$ 2.00$; 5 lbs. $\$ 8.00$, postpaid. 101 Yellows-resistant All Season. This strain has been carefully seleeted for its notable ability to
resist the "yellows." The flattened heads are of medium size and very heavy. Pkt. 10c; 1/20z. 20e;
oz. $35 \mathrm{e} ; 1$ ib. $\$ 1.00$ : Ib. $\$ 3.50 ; 5 \mathrm{lbs} . \$ 15.00$, postpaid.
Not prepaid: $10 \mathrm{lbs}$. $\$ 27.50$.

95 American Savoy. The hcads arc fairly solid and weigh 6 to 7 pounds. It has a deliciously sweet flavor and is the most tendcr Cabbage grown. The $1 / 2 \mathrm{oz}$. 15c; oz. 25c; 1/4 Ib. 75e; Ib. $\$ 2.50 ; 5$ Ibs. $\$ 10.00$ 96 Mammoth Red Rock. The larest. Nesest and very solid. Pkt, i0e: $1 / 2 \mathrm{oz}, 15 \mathrm{c} ;$, $0 \mathrm{z}, 25 \mathrm{c} ; 1, \mathrm{lb}$. and very solid. Pkt. 10 e; $120 z$. $15 \mathrm{c} ;$;
$75 \mathrm{c} ; \mathrm{lb}$. $\$ 2.50 ; 5 \mathrm{Ibs} \$ 10.00$, postpaid.

\section{COLLARDS}

178 Southern or Georgia. A tall, loose-leaved, 179 Cabbage-Collards. A cross between the cabbagc-like plant grown by market "gardeners Georgia Collard and the Charleston Wakefiel throughout the South for shipment as "Cabbage- Cabbage, bred for the hardiness of the Collard and Bunch." Grows 2 to 3 feet high and forms large, the flavor and heading qualities of the Cabbage. with rather long stems. A frost, if not too severe, It does not grow as tall as the Georgia Collard, but will improve the crop. Pkt. 10c; $0 z$. 15e; $1 / 4 \mathrm{lb} .25 \mathrm{c} ;$ the Icaves are set closer together on the stem. Pkt.

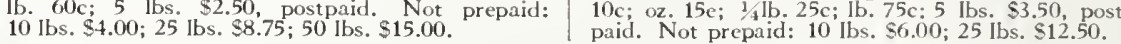

\section{CARROTS}

136 Coreless Chantenay. An earlier produce a Carrot without the usual pale yellow core. The root is as "coreless" as a Carrot can be, and, bot inside and outside, is a richer orange eolor. It is a half-long type, as is the Chantenay, and also is simi it highly. (See illustration.) Pkt. 10c; oz. 15c; $14 \mathrm{lb}$. 35c; Ib. $\$ 1.00 ; 5 \mathrm{lbs}$. $\$ 4.00$, postpaid. Not

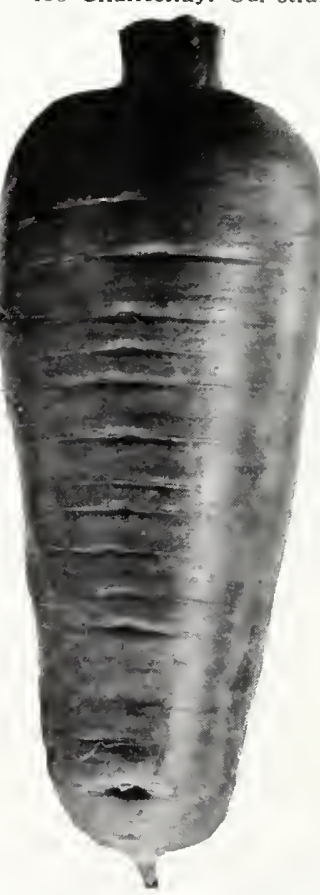
is extra-fine, clean, uniform roots with nice-sized bunching tops. Ready to pull in usually uniform. The arisp, tender and fne-flavored flesh motlets and undesirable, (See illustration, on page 3.) Pkt. 10c; 02 . 15 $\mathrm{c}^{1}$ 1/Ib. 30c; Ib. $90 \mathrm{e}$ : $5 \mathrm{Ib}$ 3.50 , postpaid. Not prepaid: 10 lbs. $\$ 6.00 ; 25$ lbs. $\$ 12.50 ; 100$ lbs. $\$ 45.00$ 129 Danvers Half-Long. This handsome, half-long, orange Carrot is for many years, produces Carrots more uniform in shape and of bettcr eolor than the strains usually sold. Roots are smooth, longer than Chantenay, and produce medium-sized tops. When mature they measure 7 to 8 inches long, tapering evenly to a blunt end. The rich orange-eolored Hesh is deep

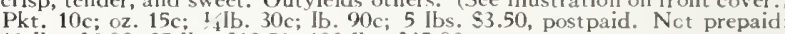
138 Scarlet Nantes. (Coreless.) A variety of French origin with superior qualities, and namcd Coreless because of the delicate texture of the uniform in size and shape. The rieh red-orange flesh is fine-grained, tender. uniform in size and shape. The rieh red-orange flesh is fine-grained, tender,

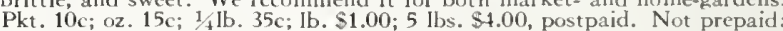
10 lbs, $\$ 700.25$ lbs si5 00

132 Oxheart. Notable for its ability to produce a good erop in soil in which other varieties will not thrive. Its blocky, stump roots are abou 5 inches long and have a small tap-root. The sweet-flavored flesh is a bright $0 \mathrm{c}$. $15 \mathrm{c}$ : $1 \mathrm{oz}$. $35 \mathrm{c} ; \mathrm{lb}$. $\$ 1.00 ; 5 \mathrm{lbs}$. $\$ 4.00$, postpaid. Not prepaid: $10 \mathrm{Ibs}$ 7.00; $25 \mathrm{lbs} . \$ 15.00$

131 Red St. Valery. A rather large-topped, pointed variety that is usually to 10 inches long. Rocts are 2 to 2,2 inches wide at the shoulder and taper evenly to the tip. They are a bright orange-scarlet eolor and have paid. Not prepaid: 10 lbs. $\$ 6.00 ; 25$ lbs. $\$ 12.50$.

\section{CARROTS FOR STOCK}

134 Large White Belgian. very thick roots are 10 to 12 inches long, with pure white skin and flesh Not repaid: 10 lbs. $\$ 6,00.25$ lbs. $\$ 12.50$

133 Long Orange. This variety is grown more for steck-feeding than for table use. It thrives best in a light, rieh soil and there produces a heavy crop. Roots are about 10 to 12 inches long, deep orange in color, and taper Coreless Chantenay Carrot Not prepaid: 10 Ibs. $\$ 6.00 ; 25$ lbs. $\$ 12.50$. 


\section{The Choicest Crops Are Harvested from Reuter's Seed}

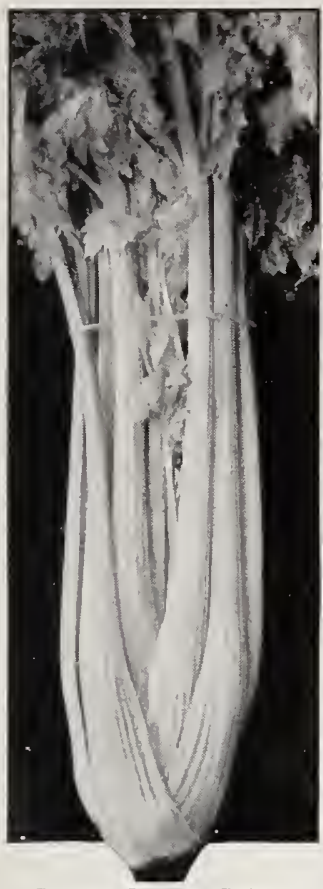

Golden Plume Celery

\section{CUCUMBERS}

215 Evergreen White Spine. Ready in 50 days. This is the finest extra-dark green White-Spine Cucumber for market- or home-garden planting. Its slender, symmetrical, tapering shape makes it well balanced and attractive. Mature fruits are about 9 inches long and $21 / 2$ inches in diameter, and are practically seedless. The sparkling white flesh is fine grained and refreshingly flavored. Plants are vigorous and produce an enormous crop. Pkt. 10c; oz. 15c; $1 / \mathrm{lb}$. 40c; lb. $\$ 1.25 ; 5 \mathrm{lbs}$. $\$ 5.00, \mathrm{p}$
paid. Not prepaid: $10 \mathrm{lbs}$. $\$ 9.00 ; 25 \mathrm{lbs}$. $\$ 20.00 ; 100 \mathrm{lbs}$. $\$ 70.00$.

229 Stays Green. A very early White-Spine Cucumber ready in about 50 days. It is one of the most important shipping varieties. The demand of commercial growers for this strain has noticeably increased, due probably to its unusual uniformity or shape and size and its ability Fruits are cylindrical in shape, very dark, glossy grecn in color, and 7 to 8 inches long. Plants produce an exceptionally heavy crop. Pkt. 10c; oz. 15c; $13 \mathrm{Ib}$. $40 \mathrm{c} ; \mathrm{lb}$. $\$ 1.25 ; 5 \mathrm{lbs}$. $\$ 5.00$, postpaid. Not prepaid: $10 \mathrm{lbs}$. $\$ 9.00 ; 25 \mathrm{lbs}$. $\$ 20.00$; $100 \mathrm{lbs}, \$ 70.00$.

231 Longfellow. Matures in 70 days. The most attractive, Iong, dark green variety. Its slender, emerald-green, almost spincless fruits are 12 to 14 inches long and are thinner, darker, and more uniform in shape than the Davis Perfect. An ideal "straight pack" variety for ship-
ping, and also very good for home-garden use. Flesh is solid, sparkling white in color, and of a delicate flavor. The fruits have very few seeds. When cown outors it decate havits equai in appearane to any hot house Cucumber. Should be planted only in the very best soil and given extra care and attention. It is a shy seeder, therefore more cxpensive, 1 Ib. $75 \mathrm{c} ; \mathrm{lb}$. $\$ 2.50 ; 5 \mathrm{lbs}$. $\$ 10.00$, postpaid. Not prepaid: $10 \mathrm{lbs}$. $\$ 17.50$; 25 Ibs. $\$ 40.00$.

227 Perfected Davis Perfect. Ready in 60 days. This is the finest selection of the popular Davis Perfect. Particularly desirable because of its flawlessness and fine cylindrical shape clear to the stem end, and its ability to hold its color for a long time after picking. We recommend it for both shipping and home-garden purposes. Fruits are a very rich green in color, averaging 10 inches in length, white-spined, slendcr, tapering at both ends, and have small seed-cavities. The high-quality flesh is solid, tender, and crisp. Pkt. 10c; oz. 15c; 1/4b. 40c; lb. \$1.25; 5 lbs. \$5.00, postpaid. Not prepaid: 10 lbs. $\$ 9.00 ; 25$ lbs. $\$ 20.00$.

221 Klondike. A medium-early, very dark green variety which produces mature fruits 7 to 8 inches in length that are uniform in size and

\section{CELERY}

155 Golden Self-blanching, Dwarf. An early maturing variety producing compact, stocky plant with yellowish green folinge turning to gold low. Stalks are ivory-white, very thick, broad, solid, crisp; brittle, and of $1 / \mathrm{le}$. $\$ 1.50 ; \mathrm{lb}$. $\$ 5.00 ; 5 \mathrm{lbs}$. \$22.50, postpaid.

161 Florida Golden. A choice new early Celery which enjoys the desirable characteristics of Goldy Plume, but is of greater height and weight and the edible portion of the stalks is larger. This strain has been bred for its long-standing qualities, and shows less tendency to produce premature seed-stalks than other sorts. The stems are brittle, crisp, free of strings, and blanch a rich cream color. Pkt. 20c; $1 / 20 \mathrm{z}$. 75c; oz. $\$ 1.25$; $1 / 4 \mathrm{lb}$. $\$ 4.00$; lb. $\$ 15.00$, postpaid.

159 Golden Plume. Positively the earliest maturing variety and one that resists blight. The handsome plants are shorter and more compact than Golden Self-blanching. Its stalks are brittle and quickly blanch to an attractive golden color They possess a pleasing nut-like flavor. (See illustration.) Pkt. 10c; 1/20z. 30c; oz. 50c; 1/\&lb. $\$ 1.50$; lb. $\$ 5.00 ; 5 \mathrm{lbs}$. $\$ 22.50$, postpaid.

156 White Plume. A showy variety which matures early and has a natural tendency to quickly blanch a pure white color. The stalks are crisp and of a very delicious flavor. Pkt. 10c; oz, 25c; $1 / \mathrm{Ib}$. 75c. Ib. $\$ 2.50$, postpaid.

158 Celeriac. Also known as Turnip-rooted Celery. The edible roots have a flavor very much like Celery, but need far less banking and keep wel With no more attention than given a crop of turnips. Used principally as a flavoring, but makes a very
satisfactory salad. Pkt. 10c; oz. 25c; 1/.1b. 75c; satisfactory salad.
$\mathrm{lb} . \$ 2.50$, postpaid.

\section{ENDIVE}

249 Large Green Curled. Rose-ribbed. Plants vigorous and resistant. Midribs of bright green outer leaves are usually tinged rose-color. The center is a dense mass of deeply divided leaves that quickly blanch to a rich creamy white
flavor is refined. Pkt. 10c: oz. 15c: $1 / \mathrm{lb}$. 35c; lb. $\$ 1.00 ; 5$ lbs. $\$ 4.00$ postpaid. Not prepaid: $10 \mathrm{lbs} . \$ 7.00$ 250 Broad-leaved Batavian (Escarole). The broad, thick, bright deep green leaves are more or less and nearly white midribs. Inner leaves form a fair head which blanches a creamy white. An excellent salad, also used like spinach. Pkt. 10c; oz. 15 . 1 . 35 c. postpaid. Not prepaid: 10 lbs. $\$ 7.00$. some time after gathering. Pkt. 10c; oz. 15c; $1 / 4$ tb. 10 lbs. $\$ 9.00 ; 25 \mathrm{lbs} \$ 20.00$

216 Early Fortune. Ready to pick in 55 days. This variety is especially desirable for its earliness, productiveness, and excellent appearance. Fruits
average 8 to 9 inches in length and are slightly color of the skin is fine and rich and holds up. Flesh
is white, crisp, solid, fine grained, and of a refreshing (See illustration.) Pkt. 10c; oz. 15c; 1/1b. 40c; Ib $\$ 1.25 ; 5$ lbs. $\$ 5.00$, postpaid. Not prepaid: 10 lbs. $9.00 ; 25$ lbs. $\$ 20.00 ; 100$ lbs. $\$ 70.00$.

223 Everbearing. An extremely small, early variety not suitable for shipping. It is principally used as a first-crop pickling Cucumber. Fruits are dareen in color and 4 to 5 inches long. If the prolific vines are kept picked, they will bear almost
Indefinit ely. Pkt. 10c; oz. 15c; $1 / 4 \mathrm{lb} .40 \mathrm{c} ; \mathrm{Ib} . \$ 1.25$;

224 Earliest of All. Ready in about 48 days. A smooth, very symetrical, blunt at the end, and very dark green color with distinct pale green line fruits of uniform size and shape that have very few seeds. The flesh is firm, crisp and white. An ideal variety for slicing or pickling. Pkt. 10c; oz. $15 \mathrm{c}$ \$1 25. 5 lbs $\$ 5.00$ postpaid. Not prepaid: 10 lbs. $\$ 9.00 ; 25$ Ibs. $\$ 20.00$.

217 Improved Long Green. Black Spine. Ready in about 60 days. Growers looking for hardy and disease-resistant variety will find this to be the best, but it matures the bulk of its crop
rather late. Fruits have a maximum length of 12 to 15 inches and are uniformly slender and an at crisp, and of a delicate flavor. The spines are well distributed instead of bunched at one end as in
inferior stocks. Largely used for pickling, and also inferior stocks. Largely used for pickling, and also
desirable for slicing. Pkt. 10c; oz. 20c; $1 / 4 \mathrm{Lh}$. 50c; lb. $\$ 1.50 ; 5$ Ibs. $\$ 6.00$, postpaid. Not prepaid 10 Ibs. $\$ 10.00$.

REUTER'S WINTER GARDEN BOOK (Ready October 1)

Your copy will be mailed upon request

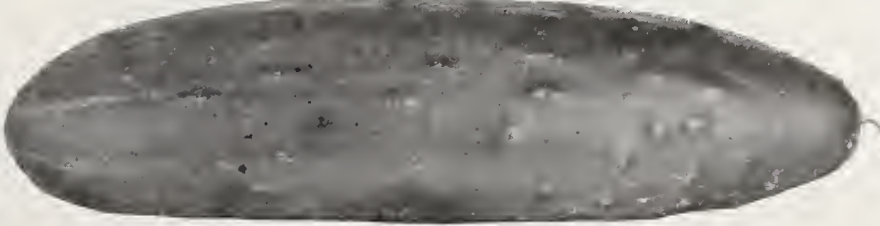

Early Fortune Cucumber shape. Retains its color, crispness, and flavor for tapering toward the blossom end. The deep green flavor. Plants are productive and disease-resistant. 5 lbs. $\$ 5.00$, postpaid. tractive dark green color. Flesh is white, very firm
CUCUMBERS, continued

225 Chicago Pickling. Ready in 50 days. This carly maturing, very small, dark green, cylindrical, all the large pickling houses. Fruits are $51 / 2$ to 6 inches long, $21 / 2$ inches in diameter, and very
uniform. The flesh is white, thick, firm, and crisp. uniform. The flcsh is white, thick, frm, and crisp.
Pkt. 10c; oz. 15c; $1 / 4 \mathrm{lb} .40 \mathrm{c}$; lb. $\$ 1.25 ; 5 \mathrm{lbs} . \$ 6.00$, postpaid. Not prepaid: 10 lbs. $\$ 9.00$.

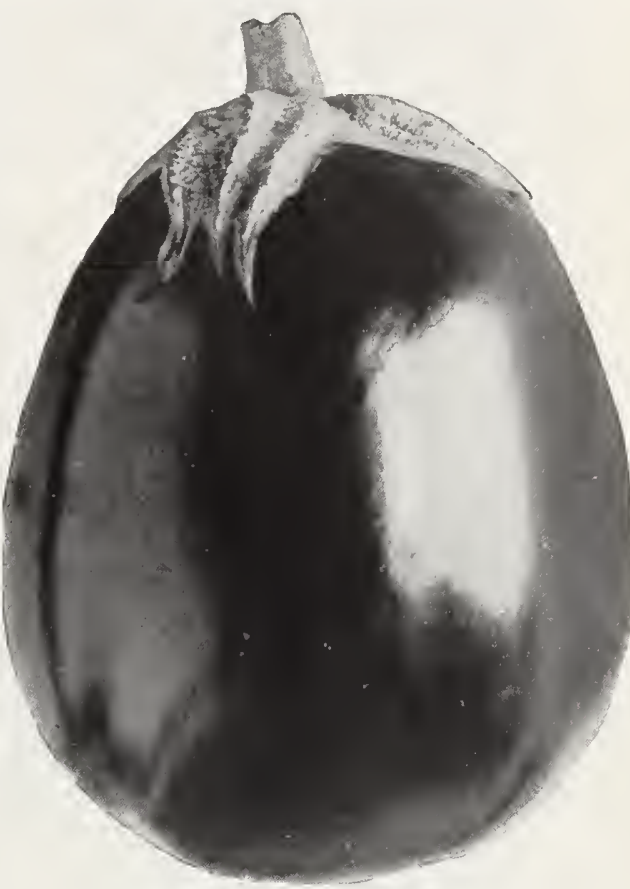

Black Beauty Eggplant

\section{EGGPLANT}

238 Black Beauty. The earliest and one of the best of the large-fruited varieties. Its large, spineless fruits are a rich, glossy, purplish black color, tion.) Pkt. $10 \mathrm{c} ; 1$ etrical egg-shape. $1 / \mathrm{lb}$. $\$ 1.40 ; \mathrm{lb}$ $\$ 4.50$; 5 Ibs. $\$ 20.00$, postpaid.

236 New Orleans Market. A distinct and excellent shipping variety. The fruits are large, long, oval, a dark purple in color, absolutely spineless, and of good quality. Bushes are vigorous and pro$10 \mathrm{c} ; 1 / 2 \mathrm{oz} .25 \mathrm{c} ; \mathrm{oz} .40 \mathrm{c} ; 1 / 4 \mathrm{lb}$. $\$ 1.40$; lb. $\$ 4.50 ; 5 \mathrm{lbs}$

240 Florida Special. An extremely early, hardy variety that is a very good shipper. This is a true high-bush sort that combines the characteristics Beauty. Bushes produce a heavy crop of rich, $45 \mathrm{c} ; 1 / \mathrm{lb}$. $\$ 1.50$; Ib. $\$ 5.00$; 5 lbs. $\$ 20.00$, postpaid. 239 Florida High-Bush. A good keeper and shipper. The vigorous, tall, upright plants hold the fruit well off the ground and prcvent rot. Fruits are clongated, cylindrical in shape, and of a purplish
color, but not as dark as the New Orleans Markct or the Florida Special. Pkt. 10c; $1 / 20 z$. 20 Ilb. \$1.00; Ib. \$3.50; 5 Ibs. $\$ 15.00$, postpaid. 237 New York Purple. A popular low-bush type that in later than Bance of somewhat larger fruits. They are color. Pkt. 10c; $1 / 20 z$. 20c; oz. $35 \mathrm{c}$; $1 / 1 \mathrm{lb}$. $\$ 1.25$; b. $\$ 4.00 ; 5$ lbs. $\$ 17.50$, post paid.

\section{DANDELION}

206 Improved Thick-leaved. A cabbaging sort supcrior to the common varreties. Pkt. 10c; $\$ 2$ oz. $35 \mathrm{c}$;

\section{FENNEL}

265 Florence. The popular Italian Finnocchio. Pkt. 10c; oz. $15 \mathrm{c} ;$
$1 / \mathrm{lb}$. $40 \mathrm{c} ; \mathrm{Ib}$. $\$ 1.25 ; 5 \mathrm{lbs}$. $\$ 5.00$; $1 / 4 \mathrm{lb}$. $40 \mathrm{c}$
postpaid. 


\section{Reuter's Bermuda Onion Seed Guaranteed 1932 Crop}

\section{ONIONS}

365 Yellow Bermuda. The most important of the Bermuda varieties. The bulbs are mediumsized, flat, and a light straw color. Their flesh is extremely mild and sweet, and of the very highest quality; It. 2.50 .5 lbs $\$ 1200$ post Naid Not prepaid: 10 lbs. $\$ 22.00 ; 25 \mathrm{lbs}$. $\$ 52.50 ; 100$ lbs. $\$ 200.00$.

366 Crystal White Wax Bermuda. Our truetype stock produces bulbs that are very flat and medium-large in size. The thin skin is pure white and crystalline - flesh white and waxy in texture. from seed planted in October. Further described on page 4.) Pkt. 10c; $1 / 20 z .15 \mathrm{c} ;$ oz. 25c; $1 / 4 \mathrm{lb} .75 \mathrm{c}$ b. $\$ 2.50 ; 5$ lbs. $\$ 11.00$, postpaid. Not prepaid 10 Ibs. \$20.00; 25 lbs. \$45.00; 100 Ibs. \$175.00. 373 Riverside Sweet Spanish. A valuable new Onion of the Spanish Valencia type. Its exceptionally large size, handsome appearance, and excellent flavor are making it one of the most popular sorts.
lt is a very gocd shipper because the bulbs are harder, frrmer, and keep better than Bermudas. When mature the globe-shaped bulbs often weigh 2 pounds and measure 4 to 612 inches in diameter. mild and very sweet, and of remarkably fine flavor. Pkt. $10 \mathrm{c} ;{ }_{2}^{1} \mathrm{oz} .20 \mathrm{c} ; \mathrm{oz}$. 35c; 1 1 lb. \$1.00; lb. $\$ 3.00$ 5 Ibs. $\$ 12.50$, postpaid. Not prepaid: 10 Ibs. $\$ 20.00$.

36.4 Prizetakers. One of the Iargest and most handsome Onions and can be successfully raised in all sections of the Central South from either spring or fall sowings. Bulbs are globular-shaped, with yellowish brown skin, and tender, white, $1 / 4 \mathrm{Ib}$. $75 \mathrm{c}$; Ib. $\$ 2.50 ; 5$ Ibs. $\$ 10.00$, postpaid. Not prepaid: 10 Ibs. $\$ 17.50$.

371 Red Creole. A strain originated in Louisiana and extensively cultivated throughout the South because of its productivity and long-keeping qualities. The bulbs are large, solid, scmi-globeshaped and of a reddish color. Flavor rather strong. Ibs. $\$ 10.00$, postpaid. Not prcpaid: 10 lbs. $\$ 17.50$.

368 Australian Brown. A late-maturing, extralong keeping Onion. Bulbs are medium-sized, semiglobe-shaped, very frm and solid in texture. The Pkt. 10c; 1/2oz. 15c; oz. 20c; 1/4 Ib. 50c; Ib. \$1.50; 369 Red Wethersfield. The bulbs are large and flat tened, but quite thick, and have a glossy, dark rcd skin. Flesh is a purplish white color, and moderately fine-grained. Pkt. $10 \mathrm{c}$; 1202 . $15 \mathrm{c}$; $02.20 \mathrm{c} ; 1 / \mathrm{b}$. $50 \mathrm{c} ; \mathrm{lb} . \$ 1.50$

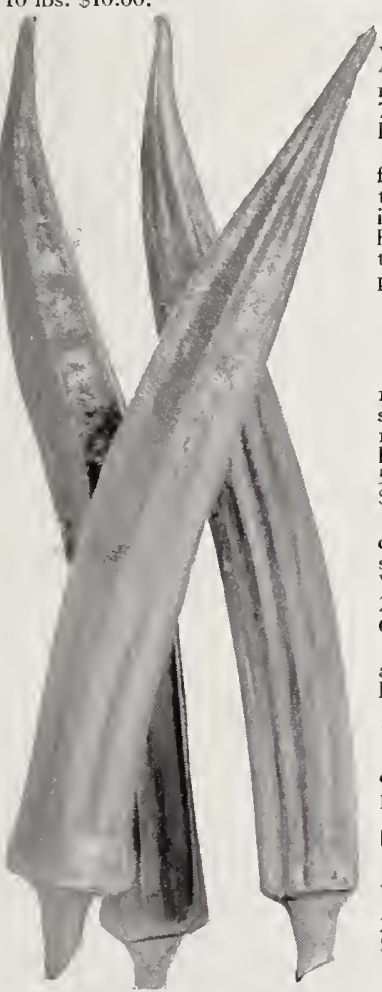

353 White Velvet. Very popular as a home-garden and local market riety. The plants are strong-growing, reaching a height of $3^{1 / 6}$ to 4 feet, and mature early. The pods are distinct in appearance, being nearly white in color. They are round, smooth, free of ridges, average 7 inches in length, and are very tender. Pkt, 10c; $0 z .15 \mathrm{c}$

354 Perkins Mammoth Long Pod. An early, heavy-producing, avorite market Okra. Ready in about 42 days. Plants grow 6 to 7 feet tall and bear a profusion of pods 8 to 10 inches long. The pods are an intense green color, straight, slender, pointed, and have the ability hold their tenderncss and color Ionger than other sorts. (See illustration.) Pkt. 10c; oz. 15c; 1/4lb. 25c; lb. 75c; 5 Ibs. \$3.00, postpaid. Not prepaid: 10 Ibs. $\$ 5.00$

\section{PEAS}

402 Pedigree Extra-Early. Ready in about 30 days. Crop so even the it can be harvested completely at one Cick straight pods are $21 / 2$ inches long, each containing 5 to 7 cven, smooth, medium-sized Peas of good table quality. Vines are productive and hardy, and grow about 2 feet tall. Pkt. $10 \mathrm{c} ; 1 / 2 \mathrm{lb} .20 \mathrm{c} ; \mathrm{Ib} .35 \mathrm{c} ; 2 \mathrm{lbs} .60 \mathrm{c}$; 5 lbs, $\$ 1.40$ postpaid. Not prepaid: $15 \mathrm{lbs}$. (pk.) $\$ 2.25$; 60 lbs. (bus.) $8.00 ; 100 \mathrm{lbs} . \$ 13.00$

404 Alaska. An early, smooth, blue Pea that is recommended for canning, market or home use. Dark green pods about 3 inches long, straight, square-ended, well filled with small, smcoth, blue-green Peas. 2 lbs. 60c; 5 lbs. $\$ 1.40$, post paid. Not prepaid: $15 \mathrm{lbs}$. (pk.) $\$ 2.25$; 60 lbs. (bus.) $\$ 8.00$; 100 Ibs. $\$ 13.00$

420 World's Record. An earlier strain of the Gradus. Vines grow about 2 feet tall and bear a profusicn of broad, pointed pods 4 inches long holding 7 to 9 large, dark green Peas of excellent quality. Pkt. 10c; $14 \mathrm{lbs}$. (pk.) $\$ 2.40 ; 56 \mathrm{lbs}$. (bus.) $\$ 8.50 ; 100 \mathrm{lbs}$. $\$ 15.00$.

406 Gradus or Prosperity. Ready in 50 days. A prolific and highquality variety. Vines grow 3 to $31 / 2$ feet tall and produce uniform green pods 4 inches Iong which hold 6 to 9 large, swect Peas. Pkt. 10c; $1 / 2$ lb. 20c; Ib. 40c; 2 Ibs. $70 \mathrm{c} ; 5$ lbs. $\$ 1.50$, postpaid.

422 Hundredfold. Ready in 60 days. A dwarf Pea producing pods 4 to $41 / 2$ inches long which contain 6 to 8 large, dark grcen Peas. Vines 16 to 18 inches tall. Resists heat. (See illustration.) Pkt.10c; $1 / 2 \mathrm{lb}$. $\$ 2.40$; 56 lbs. (bus.) $\$ 8.50$; 100 lbs. $\$ 15.00$.

418 Little Marvel. A sure cropper of unsurpassed sweetness and a and well filled. Sold out.

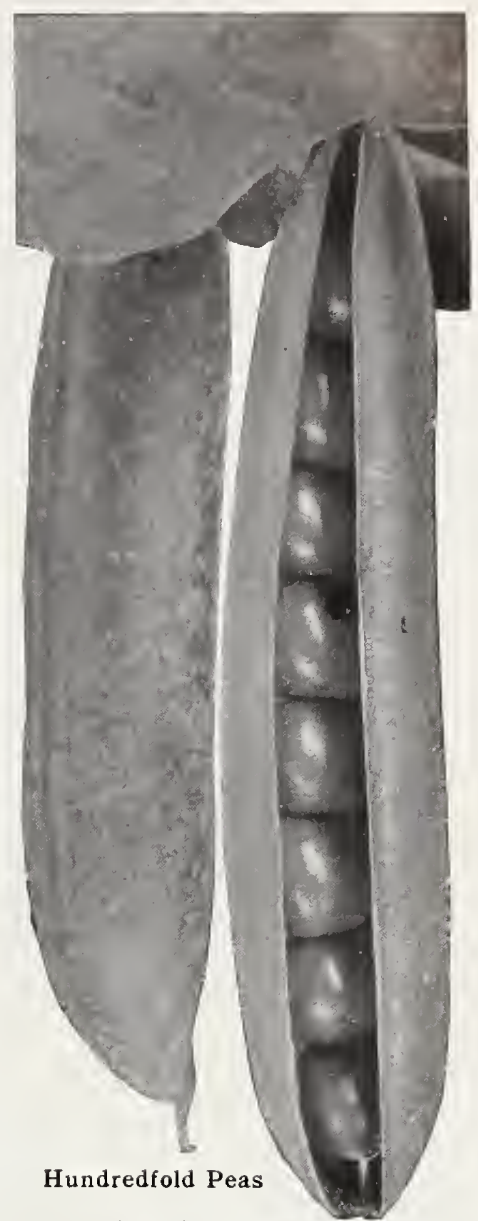

PEAS, continued

413 Laxtonian. A profitable market variety. 4 ines grow only 18 inches tall, but produce pods 10c: $1 / 2 \mathrm{lb}$. 20c; lb. 40c; 2 Ibs. $70 \mathrm{c}$; 5 Ibs. $\$ 1.50$, postpaid. Not prepaid: 14 lbs. (pk.) $\$ 2.40 ; 56$ Ibs. (bus.) $\$ 8.50 ; 100$ lbs. $\$ 15.00$

405 Thomas Laxton. Ready in 55 days. This sort is recommended for market-garden use bccause of its remarkably fine flavor and its ability to retain it until the Pcas begin to harden. Vines produce a vigorous growth 3 feet tall and bear a heavy crop
of well filled 4 to $41 / 2$-inch pods. Pkt. 10c; 1 Ib. $20 \mathrm{c}$; lb. 40c; 2 Ibs. 70c; 5 lbs. $\$ 1.50$, postpaid. Not prepaid: 14 Ibs. (pk.) $\$ 2.40 ; 56$ Ibs. (bus.) $\$ 8.50$; 00 lbs. $\$ 15.00$.

415 Dwarf Telephone. Produces pods 5 inches long tightly filled with 7 to 8 large, fine quality Peas. Vines are about 2 feet tall. Pkt. 10c; 1, Ib. repaid: 14 lbs. (pk.) $\$ 2.40$; 56 lbs. (bus.) $\$ 8.50$; 100 lbs. $\$ 15.00$

421 Bliss' Everbearing. Under favorable conditions, this variety has a prolonged bearing season. ods usually produced in pairs. They are straight, pointed, 32 inches long and hold 4 to 5 light green 1.50, postpaid. Not prepaid: 14 lbs. (pk.) \$2.40; $\$ 8.50 ; 100$ lbs. $\$ 15.00$

419 Improved Tall Telephone. Dark Podded. ines grow 4 to 5 feet tall and bear a heavy crop of well-formed pods which hold 8 to 10 very large Peas of unexcelled quality. Pkt. 10c; 12lb. 20c; lb. 40c; 14 Ibs. (pk.) $\$ 2.40$; 56 lbs. (bus.) $\$ 8.50 ; 100$ lbs. 416 Mammoth Melting Sugar. Ready in 70 days. Until pods are partly filled this variety is used like Snap Beans. Vines grow 4 to 5 feet tall pods 4 to $41 / 2$ inches long. Pkt. 10c; $1 / 2 \mathrm{lb}$. $25 \mathrm{c}$; Ib. $40 \mathrm{c} ; 2 \mathrm{lbs}$. $70 \mathrm{c} ; 5 \mathrm{lbs}$. $\$ 1.50$, postpaid. Not prepaid: 14 lbs. (pk.) \$3.00; 56 Ibs. (bus.) $\$ 11.00 ; 100$ lbs. 423 White Marrowfat. Produce vines 5 feet tall that are quite strong and bear light-colored, well-filled pods 3 inches long. Pkt. $10 \mathrm{c} ; 1 / 2 \mathrm{lb}$. 20c; paid 14 Ibs. $60 \mathrm{c}$; 5 lbs. $\$ 1.40$, postpard. Not pre100 Ibs. $\$ 13.00$ 


\section{Thousands of Truckers Plant Reuter's Vegetable Seed}

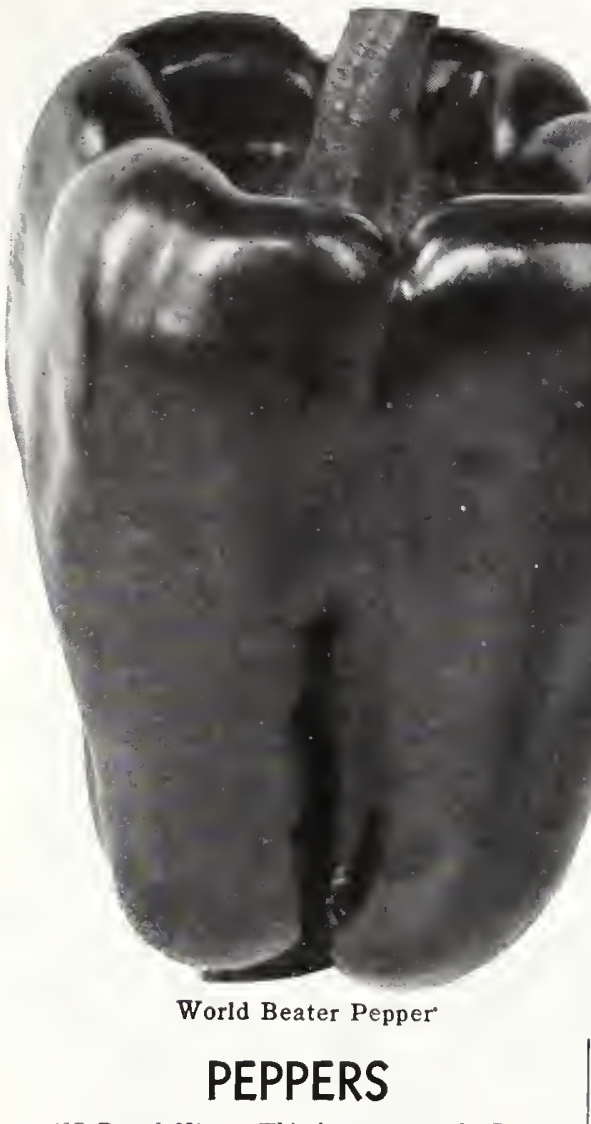

427. Royal King. This is a very early Pepper that is truly ideal for both market-and homcgardens. The perfectly snooth fruits are 4 to $41 / 2$
inches long, of a deep green color when young and a bright scarlet when ripe. Their flesh is exceptionally thick and so mild and sweet that it may be eaten raw. The plants attain a height of 2 feet and are strong, stocky, and prolific. Pkt. $10 \mathrm{c} ; 1 / 20 z$. 20c;
$\mathrm{oz}$. $35 \mathrm{c} ; 1 / \mathrm{lb}$. $\$ 1.00$; lb. $\$ 3.50 ; 5 \mathrm{lbs}, \$ 15.00$, postpaid. Not prepaid: $10 \mathrm{lbs}$. $\$ 27.50$.

440 California Wonder. The greatest of all Swect Peppers, and a shipping variety that has no equal. For commercial growers requiring a large, Pepper that is wide and medium long, with a fine flavor, this is the variety to select. The seed-stock we offer is the result of careful individual plant-
selection. Plants are upright in growth and produce an abundance of handsome, blocky fruit about 5 inches long and 4 inches widc. The fleshy walls arc often $3 / 8$ of an inch thick, which recommends it highly to shippers to distant markets. Rarely have march to the foremost rank of popularity with such rapidity as has this marvelous introduction. Pkt rapidity as has this marvelous introduction. 5 lbs. $\$ 22.50$, postpaid. Not prepaid: 10 lbs. $\$ 40.00$. 437 World Beater. Onc of the largest and most handsome of Sweet Peppers. It is a cross between earliness and longer form ol the latter and the sizc of the former. It is the most popular shipping varety grown in the South. The four - lobed fruit 3 inches. Its flesh is very thick, mild, and remarkably sweet. Color is a bright, glossy green. Excel$10 \mathrm{c} ; 12 \mathrm{nz}$. 20c; oz. $35 \mathrm{c} ; \mathrm{I}$ Ib. $\$ 1.00$; Ib. $\$ 3.50$; 429 Ruby King. A well-known, profitable, market-garden variety that is also popular for homegarden use. Fruits are 4 to 6 inches long, 3 to upright plants arc about 2 feet high and produce a heavy crop of rich, dark green Peppers with ex critical trade and thoroughly dependable. Pkt. 10c; 1 , $20 \mathrm{z}$. $20 \mathrm{c}$ oz. $35 \mathrm{co}^{1} \mathrm{Ib}, \$ 1.00$, Ib. $\$ 3.50 ; 5$ lbs. $\$ 15.00$, post paid. Not prepaid: 10 Ibs. $\$ 27.50$.

430 Pimiento. A heavy-yielding, distinct Sweet Pepper of very high quality. This variety is largely The fruits are heart-shaped, glossy grecn when young and a ruby-red when fully ripe. Their thick
PEPPERS, continued

flesh is solid, mild, and of excellent flavor. Pkt. $10 \mathrm{c} ; 120 z$. $20 \mathrm{c} ; \mathrm{oz}$. $30 \mathrm{c}$;
$1 / 4 \mathrm{Ib} 90 \mathrm{c}$; lb. $\$ 3.00 ; 5$ lbs. $\$ 12.00$, postpaid.

428 Chinese Giant. This variety produces fruits that are as much as long. These bright, rich green color when young and mature to a brilliant cherry-red. The flesh is moderately thick and very mild in flavor. Plants stand about 2 feet high and are vigorous and productive. Pkt. lb. $\$ 5.00 ; 5$ Ibs. $\$ 22.50$.

\section{HOT PEPPERS}

441 Hungarian Yellow Wax. This is a European type that has been especially imported to fill growcrs larger size than those in common use. The fruits are about 6 to 7 inches long, 11.2 to 2 inches across at the stem end, but taper evenly to a sharp point. When young they arc a waxy, pale they ripen and attgining a bricht cherry-red color when fully mature. The flesh is hignly pungent, and very desirable for picrling whole Pl. 10c; 1 . able for picking $5 \mathrm{lbs}$ \$35.00, postpaid.

434 Anaheim Chili. Produces very meaty fruits about 7 inches in length and 1 inch in diameter, with just enough pungency to make as a green chili, and makes a canned chili that $\mathrm{oz} .50 \mathrm{c} ; 1 / \mathrm{lb}$. $\$ 1.75$; $\mathrm{Ib}$. $\$ 6.00 ; 5$ lbs. $\$ 25.00$, postpaid.

431 Long Red Cayenne. The slender pods are 5 inches long and 1 inch or less thick. When young they are a deep green, but becone a bright red when they are ripe. Strong and pungent. Excellent Ib. $\$ 4.00 ; 5 \mathrm{lbs}$. $\$ 16.00$, postpaid.

\section{RADISH}

469 Early Scarlet Globe. Matures in a little over 3 weeks under normal conditions. This is probably the most popular shipping variety, due to its perfect oval shape and remarity. Skin is a brilliant scarlet, and the flesh is pure white, crisp, and of a delightful flavor. Produces tops of a convenient bunching size. (Sce illustration on page 4.) Pkt. Not prepaid: 10 lbs. $\$ 5.00 ; 25$ Ibs. $\$ 10.00$.

478 Crimson Giant. A variety with round, almost globeshapcd roots that arc ready to pull nearly as soon as the very grow until it rcaches a maximum diameter of about 2 inches. At no time dces it show the least sign of pithiness. The flesh is pungency. Pkt. 10c; oz. 15c;

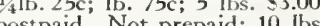
$\$ 5.00$.

461 Scarlet Turnip Whitetipped. Ready in 25 to 30 days. An exccllent bunching sort with medium-sized, nearly round roots that are a deep scarlet color, with about one-third of the lower part a distinct white The llesh is tender, crisp, and mildly तlavored. (Sec illustration, Pkt. 5 lbs. 5300 ; post paid. Not pre5 lbs. $\$ 3.00$, post paid. Not pre-
paid: $10 \mathrm{lbs} . \$ 5.00 ; 25 \mathrm{lbs} \$ 10.00$. 470 French Breakfast. A quick-growing Radish with small olive-shapcd roots colored tip at the bottom. Flesh is whitc, meaty, and pungent, but delight fully flavorcd. Pkt. $10 \mathrm{c}$; oz. 15c; ${ }_{4}^{1} \mathrm{lb} .25 \mathrm{c} ; 1 \mathrm{~b} .75 \mathrm{c} ; 5 \mathrm{lbs}$ 10 lbs, $\$ 5.00$.

462 Long Brightest Scarlet. The earliest long scarlet Radish. Roots are vivid scarlet with a white tip. Tops are
fairly small. Flesh is icy white,

\section{RADISH, continued}

crisp, and tender until fully grown. This variety makes a truly handsome appearance. Pkt. 10c; Not prepaid: 10 lbs. $\$ 5.00$.

463 Cincinnati Market. A desirable early market variety and one popular with shippers in this section. The smooth, stranght, slender roots attain a growth of 6 to 7 inches in length. Skin is a deep and mild. Pkt.j10c; oz. 15c; 1 lib. 25c; lb. $75 \mathrm{c}$; $5 \mathrm{lbs}$ $\$ 3.00$, postpaid. Not prepaid: 10 lbs. $\$ 5.00 ; 25$ Ibs. $\$ 10.00$.

467 White Icicle. The roots of this variety are waxy white and grow about 6 inches long. Their white flesh is crisp, tender even when fully mature and agreeably snappy in flavor. This is an old $1 ; \mathrm{Ib} .25 \mathrm{c} ; \mathrm{lb}$. $75 \mathrm{c} ; 5$ Ibs. $\$ 3.00$, postpaid. Not prepaid: 10 Ibs. $\$ 5.00 ; 25 \mathrm{Ibs} . \$ 10.00$.

471 Improved Chartier. Later maturing than other long scarlet sorts. Ronts are slender and 7 to 8 inches long. The skin is bright scarlet-rose, shad-
ing to white at the tip. Flesh is white, crisp, and of a fine flavor. Produces medium-sized tops. Pkt.

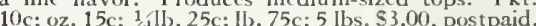
Not prepaid: 10 Ibs. $\$ 5.00 ; 25$ lbs. $\$ 10.00$

468 Long White Vienna (Lady Finger). A long, white varicty which matures in 25 days. The roots are 6 to 7 inches long, slender and slightly lb. $75 \mathrm{c} ; 5 \mathrm{lbs} . \$ 3.00$, postpaid. Not prepaid: $10 \mathrm{lbs}$. $\$ 5.00$.

\section{Winter Varieties}

472 Long Black Spanish. Roots are 8 to 9 inches long and 2 to 3 inches in diameter. The skin is nearly black, but the flesh is pure white, solid, juicy and pungent, yet well flavored. A very 5 lbs. $\$ 4.00$, postpaid. Not prepaid: 10 lbs. $\$ 7.00$. 477 Chinese Rose Winter (Scarlet China). A desirable late-maturing sort. Mature roots are 4 to 5 inches long. Skin is a rose-red color. Flesh is pure white, fine-grained, crisp, and mildy pungent. postpaid. Not prepaid: $10 \mathrm{lbs} \$ \$ 7.00$

465 Chinese White Winter (Celestial). The slightly oval-shaped blunt-based roots average 15 inches long and 4 to 5 inches in diameter. Fles crisp flesh is agrecably mild. Pkt. $10 \mathrm{c}$; oz. $15 \mathrm{c}$; $1 / 4 \mathrm{lb}$. 30c; lb. $90 \mathrm{c}$; 5 lbs. $\$ 4.00$, post paid.

\section{SALSIFY}

492 Mammoth Sandwich Island. Also known "egetable Oyster." This variety is the most popular now under cultivation. Frost does not
injure the roots. Pkt. 10c; oz. 20c; $1 / \mathrm{lb}$. $60 \mathrm{c}$; lb. $\$ 2.00 ; 5$ Ibs. $\$ 7.50$, postpaid.

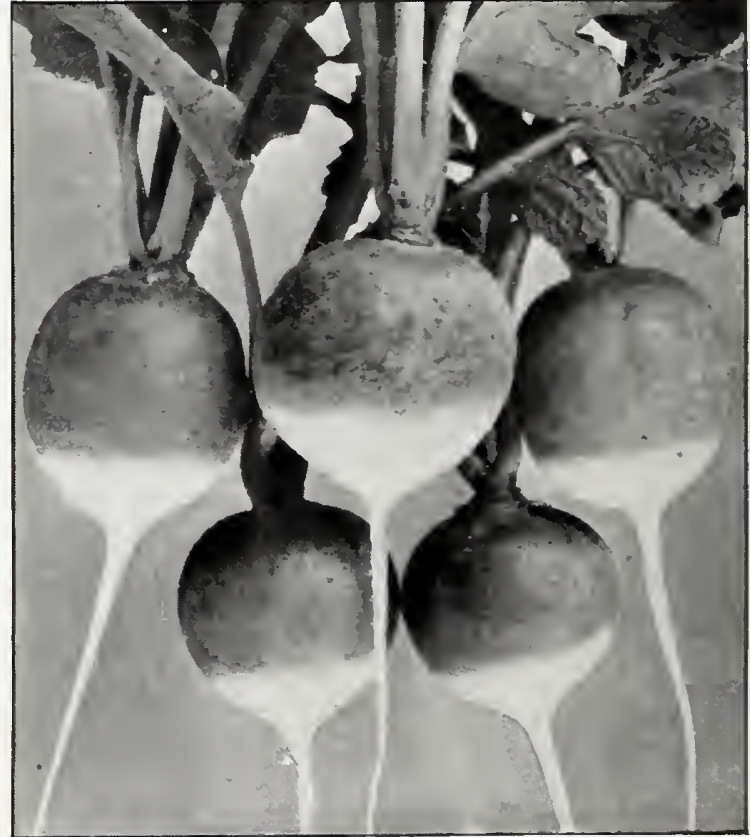

Scarlet Turnip White-tipped Radish 


\section{Reliable Seedsmen for More Than a Half Century}

\section{SPINACH}

511 Old Dominion. A sensational new Savoy-leaved type developed at the Virginia Experiment Station after 20 years of careful selection and breeding. It is truly a beautiful Spinach of the Bloomsdale type, upstanding, heavily savoyed, dark colcred, and very slow in running to seed, thus eliminating the worst deficiencies of the ordinary Savoy. It possesses all the
blight-resisting qualities of the Virginia Blight-resistant. The growth is compact, the blight-resisting qualities of the Virginia Blight-resistant. The growth is compact, the
foliage is dark bluish green and heavily crumpled, except at the very leaf-tips. Withfoliage is dark bluish green and heavily crumpled, except at the very leaf-tips. With-
stands heat and cold as well as any variety, and will remain in good condition as long as any late-sceding Bloomsdale. We highly recommend this outstanding type to every large commercial grower and shipper of Spinach in the South. (See illustration on
page 5.) Pkt. 10c; oz. 15c; 1/4 Ib. 25c; lb. 75c; $5 \mathrm{lbs}$. $\$ 2.50$, postpaid. Not prepaid: 10 lbs. $\$ 4.00 ; 25$ Ibs. $\$ 8.00 ; 100$ Ibs. $\$ 30.00$.

502 Bloomsdale Savoy. Extra-Dark Green. A new, beautiful, better, and darkercolored strain. The plants, which are quite early in maturing, have a fresh appearance for a longer time after being cut, because of the deep, glossy green color. Its large, fleshy leaves are deeply erumpled and remain in prime condition longer than those of the old Savoy-leaved. We are greatly impressed with this attractive and outstanding improvement. (See illustration on page 5 .) Pkt. $10 \mathrm{c} ; \mathrm{oz} .15 \mathrm{c} ; 1 / 1 \mathrm{lb} .20 \mathrm{c} ; \mathrm{lb}$.
$\$ 2.00$, postpaid. Not prepaid: $10 \mathrm{lbs} . \$ 3.00 ; 25 \mathrm{Ibs} \$ \$ 5.00 ; 100 \mathrm{lbs}$ \$15.00.

507 Long-standing Bloomsdale. A new strain of notable merit that has already become a favorite with commercial growers because of its splendid performance. Its attractive, deep, glossy green leaves are intensely crumpled and very uniform. The plants are almost as early and quick-growing as the Bloomsdale, but they will stand in marketable conditicn 10 to 14 days longer before bolting to seed, which is a valme to spring because it is seldom seriously injured by the first warm days, which often ruin completely the early-maturing Bloomsdale. Pkt. $10 \mathrm{c} ; \mathrm{oz} .15 \mathrm{c} ; 1 / 4 \mathrm{Ib} .20 \mathrm{c} ; \mathrm{Ib} .60 \mathrm{c} ; 5 \mathrm{Ibs} . \$ 2.00$, postpaid. Not prepaid. 10 lbs. $\$ 3.00 ; 25$ Ibs. $\$ 5.00 ; 100$ Ibs. $\$ 18.00$.

508 Virginia Blight-resistant. A splendid Savoy type developed by the Virginia Experiment Station to resist blight, "yellows" or mosiac. These qualities make it especially well suited for cultivation in sections troubled with disease. For late planting, even where disease is not prevalent, it is superior to some other varieties. Pkt. $10 \mathrm{c} ; \mathrm{oz}, 15$
paid: 10 lbs. $\$ 3.00 ; 25$ lbs. $\$ 5.00 ; 100$ lbs. $\$ 18.00$.

509 Nobel Giant-leaved. The largest-leaved Spinach. It is also the best of the smooth-leaved varieties. The leaves are medium green, very uniform, rounded, slightly crumpled, succulent, tender and of enormous size. It is early and a very quick grower. The crop it produces is very heavy bolting to seed. In this characteristic it far outstands the Flanders and the Viroflay. An ideal canning sort. Excellent for both market- and home-garden use. (See illustration.) Pkt. 10c; Not prepaid: 10 lbs. $\$ 3.00 ; 25$ Ibs. $\$ 5.00 ; 100$ lbs. $\$ 16.00$.

504 Viroflay. A favorite of shippers in Louisiana and Texas. It makes a rapid growth and forms cluster of very large, upright, slightly crumpled, thick leaves of medium green color, and good quality. They are usually arrow-shaped, but sometimes rounded. Pkt. $10 \mathrm{c} ; 0 z .15 \mathrm{c} ; 1 / 4 \mathrm{lb}$. 20c;
lb. $50 \mathrm{c} ; 5$ lbs. $\$ 2.00$, postpaid. Not prepaid: 10 lbs. \$3.00; 25 Ibs. \$5.00; 100 lbs. \$15.00.

503 Flanders. A desirable sort for bunching purposes. It is early and vigorous growing, and is extensively planted in Louisiana. Leaves are sometimes rounded. They are inclined to be flat and fairly smooth. Pkt $10 \mathrm{c}$. $15 \mathrm{c}$; 1 . Ib. $50 \mathrm{c} ; 5$ lbs. $\$ 2.00$, postpaid. Not prepaid:
NEW ZEALAND SPINACH 505 This is an entirely distinct, variety and known as the "Cut-and-Come-Again" Spinach. It makes a luxuriant growth during hot weather and A very valuable addition to the supply of summer "greens." Plants are bushy in form and their leaves are succulent, rich green in color, and of an excellent flavor. As the tops are cut the plants produce sidc shoots and in a few days another crop is ready. Flourishes in any kind of soil and does well during hot weather, but cannot stand frost as do other varieties. Pkt. 10c; oz. 15c; 14. 25c; lb. $75 \mathrm{c} ; 5$ lbs. $\$ 3.00$, postpaid. Not prepaid: 10 lbs. $\$ 5.00$.

\section{Reuter's Winter Garden Book} This complete cultural and descriptive guide of all winter- and spring-flowering bulbs, flowers, nursery stock and winter lawn grass A copy will be reserved for you immediately A copy will be reserved for you immedis
upon receipt of your name and address.
Nobel Giant-leaved Spinach

\section{SQUASH}

515 Early White Bush. Our superb, very early strain of the well-known White Scalloped or the Especially desirable rather small, round -resistant vines. Fruits scalloped edges. They measure 7 to 8 inches $a c r o s s$, and the comes. The coust in color. The firm flesh is of a delightful flavor. (See illustration.) Pkt. 10c; oz. 15c; 1/4 Ib. 40c; Ib. $\$ 1.25 ; 5$ Ibs. $\$ 5.00$, postpaid. Not prepaid: 10 lbs. $\$ 9.00$

525 Early Summer Crookneck. Ready in 48 days. This variety is more generally used than any other yellow summer sort. Vines arc of bunch yellow fruits that measure 10 to 12 inches in diameter when fully grown. The surface is densely covered with warts and is very hard when fruit is
ripe. Flesh is a pale cream-color, firm and tender. ripe. Flesh is a pale cream-color, firm and tender. $40 \mathrm{c}$; lb. $\$ 1.25 ; 5 \mathrm{lbs} . \$ 5.00$, postpaid. Not prepaid: 10 lbs. $\$ 9.00$

518 Giant Summer Crookneck. This is a

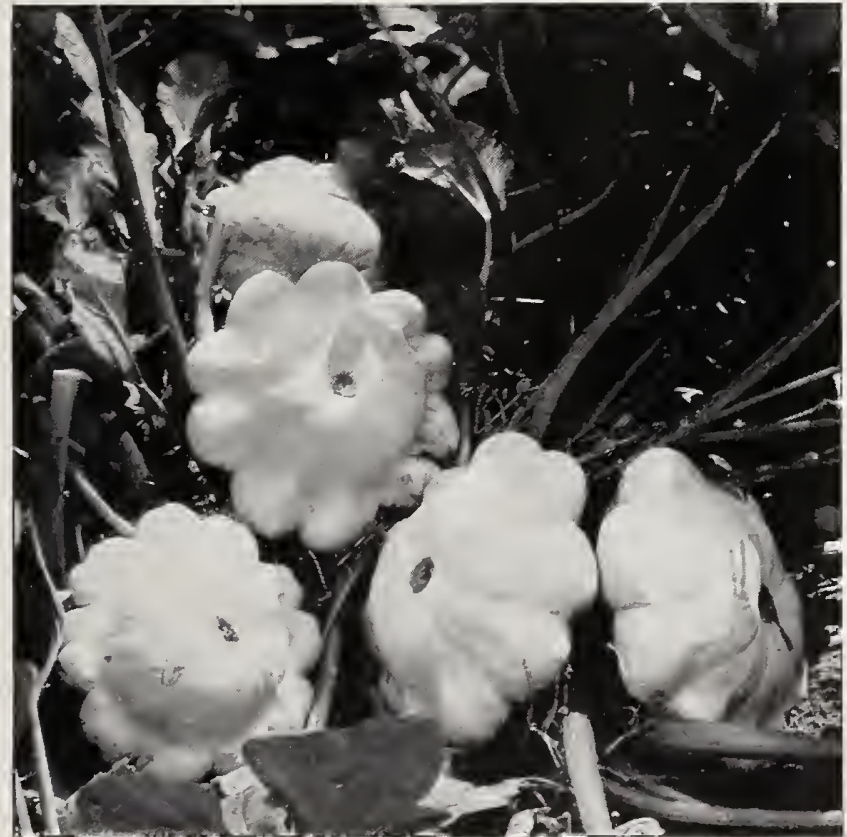

not as prolific, but the fruits are twice its size. The vines are of bush habit and grow vigorously. The fruits are covered with a finely warted, golden-yel skin and are 18 to 24 inches long when mature. The flavor is buttery and delicious. Pkt. 10c; oz. 15c; $1 / 4 \mathrm{Ib}$. 40c; Ib. $\$ 1.25 ; 5 \mathrm{Ibs} . \$ 5.00$, postpaid. Not prepaid: 10 lbs. $\$ 9.00$.

526 Giant Summer Straightneck. This selection of the Giant Summer Crookneck is free of the crooked neck and is rapidly becoming the preference of commercial growers and shippers because of the greater ease with which it have a deeper, thicker flesh of the samc excellent quality as the original strain. They mature early and are 18 to 20 inches long. We do not hesitate in recommending this variety to critical growers wishing to secure the best possible seed strain. Pkt. 10c; oz. 20c; 1 1 L b. 50c; lb. $\$ 1.50 ; 5$ lbs. $\$ 6.00$, postpaid. Not prepaid: 10 lbs. $\$ 10.00$.

517 Italian Marrow (Cocozelle). Grows to a length of 6 to 8 inches in 60 days and at this size is in prime condition for picking. The skin is dark green, green fornes marbled with yellow and light green as it matures. The pale bush habit, and the fruits, tender, and of excelicnt quality. The vines are of about 5 inches in diameter. Pkt. $10 \mathrm{c}$; oz. $20 \mathrm{c} ; 1 / \mathrm{ll}$. $50 \mathrm{c}$; lb. $\$ 1.50 ; 5 \mathrm{lbs}$. $\$ 6.00$, postpaid. Not prepaid: 10 Ibs. $\$ 10.00$.

524 Zucchini. This new Italian Squash or Vegetable Marrow has met with great favor becausc it is a delightful summer variety. It is especially popular with southern shippers. The fruits should be picked when they are $1 / 1$ lb. $40 \mathrm{c}$; lb. $\$ 1.25 ; 5 \mathrm{lbs}$. $\$ 5.00$, postpaid. Not prepaid: $10 \mathrm{lbs} . \$ 9.00$.

\section{ROQUETTE}

483 Young leaves ready for cutting in 6 weeks. The leaves of this hardy annual are long, smooth, and glossy. When young they are used like mustard. Ib. $\$ 2.00$, postpaid.

\section{SORREL}

Early White Bush Squash. Pkt. 10c

497 Leaves can be cut in about 2 months from planting. When well grown, z. 20c; $1 / 4 \mathrm{lb}$. 60c; lb. $\$ 2.00$, postpaid. 


\section{Reuter's Seeds Are the Best "Seeds for the South"}

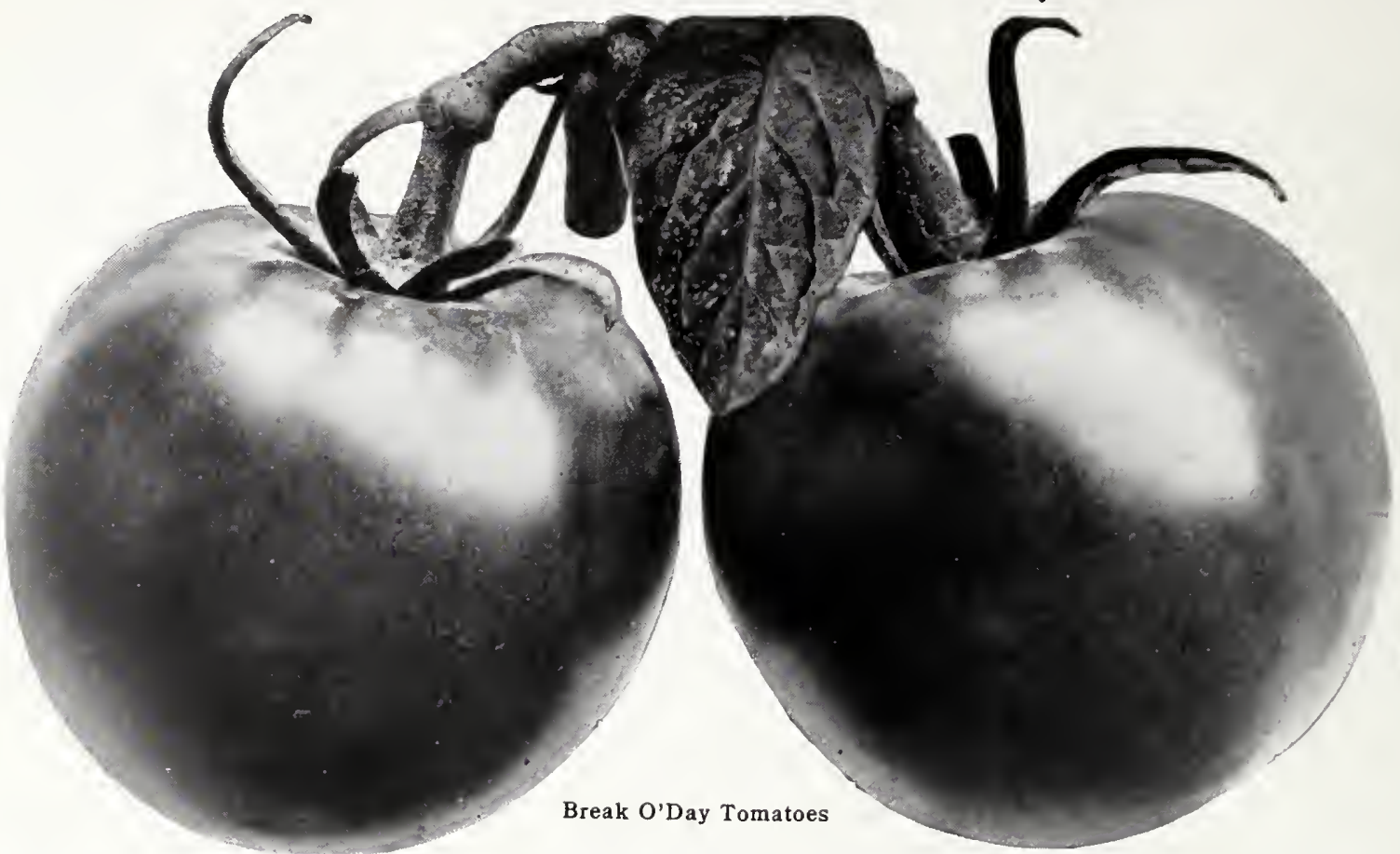

\section{TOMATOES} BREAK O'DAY

546 The development of this extremely important strain by the United States Department of Agriculture has been recognized as a notable achievement in the breeding of glole-shaped Tomatoes. It is principally important to growers and shippers because it is to to 12 days earlier tban the Norglobe which it resembles in size, shape, and color. Its hesh is thicker and it will stand packing and shipping very well. A heavy cropper. This variety $40 \mathrm{c} ; 1$ 1 Il . $\$ 1.30$; lb. $\$ 4.50$; 5 Ibs. $\$ 20.00$, post paid. Not prepaid: 10 Ibs. $\$ 35.00$.

570 Gulf State Market. A heavy-yielding, blight-resistant variety. It is slightly earlier than livingston Globe. The large fruits arc a true globe shape, with firm, perfectly smoot $\mathrm{l}$, purplish pink skin. Its flesh is solid and compiratively free of seeds. It is extensively planted throughout the South for shipping purposes. Vines make a strong

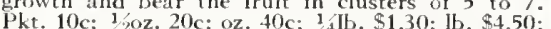
5 lbs. $\$ 20.00$, postpaid. Not prepaid: 10 Ibs. 575 Marglobe. This is the variety most desired
by commercial growers and shippers. Our secd has by commercial growers and shippers. Our seed has the Unitcd States Department of Agriculture. The

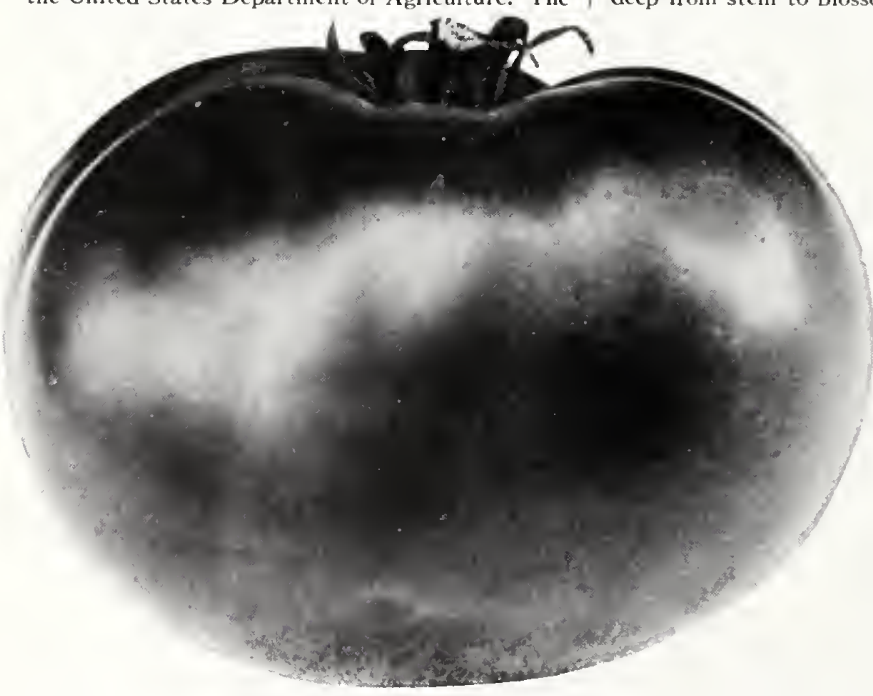

Louisiana Pink Tomato early-maturing, sturdy, and disease-resistant plants produce an abundance of large-sized, smooth, perscarlet color. The uniform depth of the fruit assures a perfect pack. Centers are heavy, meaty, and the core small. It has proven itself more resistant to injuries resulting from excessive moisture than other commercial varieties. Pkt. 10c; 1/20z. 20c; oz. 35c; ${ }_{4}^{1} \mathrm{lb} . \$ 1.25$; Ib. $\$ 4.00 ; 5$ Ibs. $\$ 18.00$, postpaid. Not prepaid: 10 lbs. $\$ 32.50$.

563 Earliana. The earliest and one of the best Tomatoes. Vines are flat, open, and rather small, but they bear a heavy crop of large, round, smooth, uniform, deep scarlet-colored fruits clustered toward their centers. The flesh is solid, rich and finely flavored. Pkt. 10c; $120 \mathrm{Oz}$. 20c; oz, 30c; 11 lb. paid: 10 Ibs. $\$ 2500$.

552 John Baer. An extra-early, bright red variety of unusual quality. The large, solid fruits are nearly round, smooth, firm, and possess an growth, but they are very productive. Pkt. 10c; 1/20z. 20c; oz. 30c; 1/4 Ib. $\$ 1.00 ; 1 \mathrm{lb} . \$ 3.50 ; 5$ Ibs. $\$ 15.00$, post paid. Not prepaid: $10 \mathrm{lbs} . \$ 25.00$.

550 Clark's Early. A medium-early Tomato of handscme deep scarlet color. This is the variety so Crtensively planted in Southwest Texas Rio The vigorous vines are very prolifie. Fruits are large, semi-globe-shaped, sinooth, and remarkably
decp from stem to blossom end. The flesh is well colored, thick, firm; seed-pockets and eore are small. Pkt. 10c; ${ }_{2}^{1}$ oz. 20c; oz. 30c; 1/4lb. $\$ 1.00$; lb. $\$ 3.50$; 5 lbs. $\$ 15.00$, postpaid. Not prepaid: 10 lbs. $\$ 25.00$. shivingston Globe. One of the greatest shipping Tomatoes. Vines are vigorous and produce fectly globe-shaped, always mooth. Skized, pergectly globe-shaped, always smooth. Skin is a fine glossy rose-color tinged purple. Fesh is firm and ripens evenly. A mild, pleasant-flavored variety

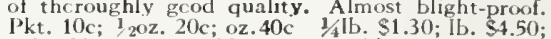
Pt. 10c; 20z. 20c; 0z. 40c 1/4b. \$1.30; lb. \$4.50; 557 June Pink. A handsome, early, pink-fruited 557 June Pink. A handsome, early, pink-fruited
variety that is popular on all markets. It possesses good shipping qualities such as uniform size and solid flesh, which have made it one of the most widely cultivated Tomatoes in South Texas. Vines bear a truly enormous crop. Fruits are nearly globeshaped, medium-sized, and smooth. Pkt, $10 \mathrm{c}$; $1 / 2 \mathrm{oz}$. 20c; oz. 40c; 1. Ib. $\$ 1.30$; II. $\$ 4.50 ; 5 \mathrm{lbs}$. $\$ 20.00$, post paid. Not prepaid: $10 \mathrm{lbs}$. $\$ 35.00$. 573 Louisiana Pink. Wilt-resistant. Our seed is grown from stock developed by the Louisiana Experiment Station and bred for its special wilt-resistant qualities. Not only does it resist discase, but single vines of en produce 150 or more perfect fruits. It easily outyiclds any other strain. Fruits are mediumearly, pink-skinned, smooth-fleshed, and of good size. They are almost globe-shaped and are borne in large $40 \mathrm{c} ;{ }_{4} \mathrm{Ib} . \$ 1.30$; Ib. $\$ 4.50 ; 5 \mathrm{Ibs}$. $\$ 20.00$, postpaid. Not prepaid: 10 lbs. $\$ 35.00$.

574 Louisiana Red. Wilt-resistant. Same type as the Louisiana Pink, except the skin is red in color. Pkt. $15 \mathrm{c} ; 1 / 20 \mathrm{Oz}$. 30c; oz, $50 \mathrm{c} ; 1 / 4 \mathrm{lb} . \$ 1.50 ; \mathrm{Ib}$. $\$ 5.50 ; 5$ lbs. $\$ 25.00$, postpaid.

571 Norton Wilt-Resistant. A main-crop, scarlet-fruited variety very similar to the Stonc. One of the best long-distance shippers. Bred by the United States Department of Agriculture to resist fusarium wilt. Fruits are from medium to large size, smooth and solid. The vines bear a good crop. The flesh is very solid and of the best eating quality. Pkt. $10 \mathrm{c} ; 1 / 20 \mathrm{z} .20 \mathrm{c} ; 0 z .35 \mathrm{c}$
$1, \mathrm{Ib} . \$ 1.25 ; \mathrm{Ib} . \$ 1.00 ; 5 \mathrm{Ibs} . \$ 18.00$, post paid. Not prepaid: $10 \mathrm{Ibs} . \$ 32.50$. 565 Stone. For shipping purposes this is one of the best, and it is extensively used for canning. It is a large-fruited, main-crop or late bright red variety Fruits are round, smooth, and uniform. The flesh has a fine mildly acid flavor. Unsurpassed for slicing. Pkt. 10c; 1 2oz. 20c; oz. 30c; $1 / 4 \mathrm{lb}$. $\$ 1.00 ; \mathrm{lb} . \$ 3.50$ 5 Ibs. $\$ 15.00$, post paid. Not prepaid: 10 Ibs. $\$ 25.00$.

548 Redfield Beauty. A good shipper that is less liable to rot than many other sorts, Large, prolific vines produce handsome, large, uniform smooth, solid fruit of a purplish pink color. Pkt. 10c; 1/20z. 20c; oz. 30c; 1/4 Ib. $\$ 1.00$ Ib. $\$ 3.50 ; 5$ lbs. $\$ 15.00$, postpaid.

572 Brimmer Tomato. There is no other Tomato that can compare to this variety in size, weight, solidity, quality, or productiveness. The enormous, well-shaped, purplisli pink fruits measure 15 to 18 inches in circumference and weigh 3 pounds or more. They are nearly solid, meaty flesh with very few seeds and absolutely no core. The flavor is mild, delicate, and remarkably free of acidity. It is recognized as the finest slicing Tomato. Pkt. 15c; $1 / 20 \mathrm{z} .35 \mathrm{c}$ oz. $60 \mathrm{c} ; 1 / 4 \mathrm{lb} . \$ 2.00 ; \mathrm{lb} . \$ 7.50 ; 5 \mathrm{lbs}$. $\$ 35.00$, postpaid.

567 Ponderosa. Produces a great abundance of magnificently large fruit that is delicious in favor and perfect in shape. Fruits are a brautiful rich pin color, smooth, and uniform. The flesh is astonishingly solid, praetically free of seeds, and of a delightful subacid flavor. Not quite as gond as the Brimmer. Pkt. 15c; 1/20z. 35e; oz. 60c; 1/4 Ib. \$2.00; lb. \$7.50; 5 lbs. $\$ 35.00$, post paid. 568 Golden Ponderosa. Equals the Ponderosa in size and weight but

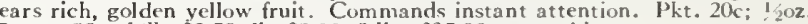
$45 \mathrm{c} ; 0 \mathrm{z} .80 \mathrm{c} ; 1 / 4 \mathrm{lb} . \$ 2.50$; lb. $\$ 8.00 ; 5$ lbs. $\$ 35.00$, post paid. 


\section{Prompt Special Quotations Made on Larger Quantities}

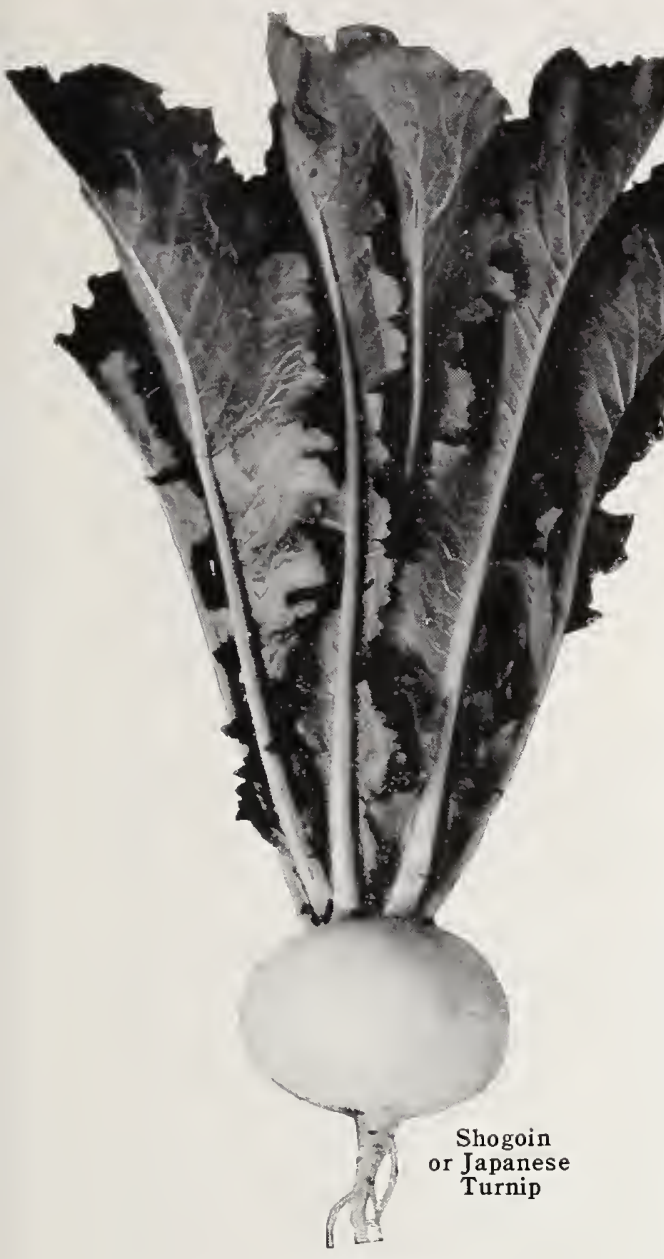

\section{TURNIPS}

585 White Egg. A very early, oval or eggshaped variety with smooth, clear white roots of medium size. The flesh is pure white, fine-grained, and sweet. Pkt. 10c; oz. 15c; 1/4lb. 20c; lb. 50c;
5 lbs. $\$ 2.00$, postpaid. Not prepaid: 10 lbs. $\$ 3.00$. 580 Early Flat White Dutch. Strap-leaved. Very early and popular white table Turnip. Foliage fine-grained and sweet. Best for table use when
TURNIPS, continued about $2 \frac{1}{2}$ inches in diameter. Pkt. $10 \mathrm{c}$ oz. 15c; 10 , 20 ; 1 b.

579 Early Purple-Top. Strap-leaved. This is a very early and productive variety that is widely cultivated. The rather flat, medium-sized roots are purto white toward the base. Flesh is white, tender and swcet. Pkt. 10c; oz. 15c; $1 / 1 \mathrm{lb}$. prepaid: 10 lbs. $\$ 3.00$

578 Purple-Top White Globe. Our strain of his well-known Turnip produces almost perfect globe-shaped roots, purplish red on the upper part and the base. It is very largely throughout the South. A heavy cropper that produces lare attractive tops well adapted to bunching. Flesh is white, firm, crisp, and mildly flavored. (See illustration.) Pkt. 10c; oz. 15c $1 / \mathrm{lb} .20 \mathrm{c}$. lb $50 \mathrm{c}$ - 5 lbs. $\$ 2.00$ postpaid. Not prepaid: $10 \mathrm{lbs}$ \$3.00; 25 Ibs. $\$ 7,00$

582 Snow-White Globe. Strap-leaved. A very large sort, producing white, globe-shaped roots that are smooth and solid. Flesh is pure white, frrm, crisp, and of excellent quality. Pkt. paid. Not prepaid: 10 lbs. $\$ 3.00$.

592 Shogoin or Japanese. A new foliage Turnip from to most other varieties. The Icaves grow about feet high and are of upright habit, which makes them almost immune to insect attacks. They are broad, crisp, tender, and of a superbly mild flavor. Roots arc larse, pure white semi-globular, and of a good table quality. This type is more often grown for the tops than for the roots. (Sce illustra-

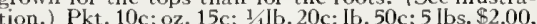
postpaid Not prepaid: 10 Ibs $\$ 3.00 ; 25$ lbs $\$ 7.00$ 589 Purple-Top Milan. The earliest Turnip. Roots are medium-sized, smooth, flat. Flesh is white, crisp, and of a delicate, swcet flavor. The upper half of the bulbs is a rich purple color, but $1 / 4$ lb. 25 c; Ib. 75 c; 5 lbs. $\$ 3.00$, postpaid. Not pre10 lbs. $\$ 5.00$.

590 Pomeranian. Roots are globe-shaped or slightly flattencd. The skin is very white and mooth. A heavy cropper, and especially good for

\section{TURNIP COLLECTION} $35 c$

One full ounce of the following seven varieties: Purple-Top White Globe Extra-Early White Egg Amber Globe Purple-Top Strap-leaved Early Flat White Dutch Seven Top

American Purple-Top Rutabaga

We also offer $1 / 4 \mathrm{lb}$. of each of the above for only $90 \mathrm{c}$, postpaid (regular value $\$ 1.40$ )
TURNIPS, continued

The upright tops make The upright tops make palatable greens. Pkt. 10c Not prepaid: 10 lbs. $\$ 3.00$

588 Long White Cowhorn. Roots are often 12 to 15 inches long, 3 inches in drameter, and and white below. Flesh is white, fine-grained, and cnder. For table use they are best when 3 to inches long, but may bc allowed to attain their fulI growth, if used for stock-feeding. Pkt. 10c, Oz. 15c paid: $10 \mathrm{lbs}$. $\$ 3.00$.

584 Seven Top. Docs not produce an edible root. Cultivated cxtensively in the South for the tops which are used for "greens." It is very hardy with canners and shippcrs. Desirable for homegarden planting. Pkt. 10c; oz. 15c; $1 / 1 \mathrm{Ib}$ 20c $\$ 3.00$; 25 lbs. $\$ 7.00$,

586 Amber Globe. A yellow-fleshed variety Roots are globular-shaped and largc. Skin is smooth, clcar yellow, cxcept the top which is tingcd with green. Pkt. 10c; oz. 15c; 1/4b. 20c; lbs. $\$ 3.00$.

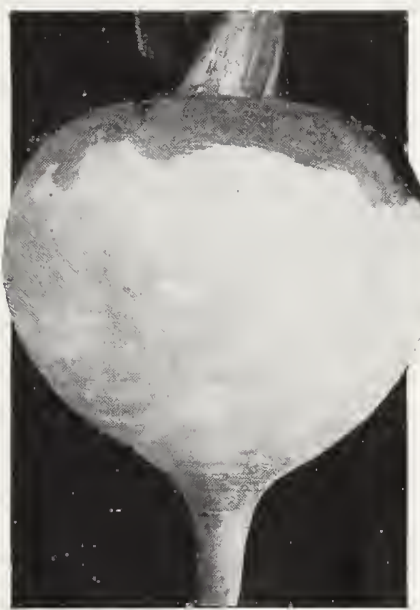

Purple-Top White Globe Turnip

\section{RUTABAGA}

591 American Purple-Top. The very best purple-top grown. The roots are large, globular, pale ycllow with a purplc top. Its smooth ffesh is tender and sweet. The best sort for both table use and stock-feeding. Pkt. 10c; oz. 15c; $11 \mathrm{lb} .20 \mathrm{c}$ lb. 60 c; 5 lbs. $\$ 2.50$, postpaid. Not prepaid: 10
lbs. $\$ 4.00 ; 25$ Ibs, $\$ 7.50$.

\section{REUTER'S VEGETABLE PLANTS}

\section{"FROSTPROOF" CABBAGE PLANTS}

These plants will stand frost with little or no damage; however, "frostproof" does not mean "freezeproof." Shipment made dircct to Charleston Wakcfield and Early Flat Dutch. Postpaid prices: 100 plants 50c: 500 for $\$ 1.50$ 1000 ar prices: 100 plants $50 \mathrm{c}$, 00 for $\$ 1.50$ less than 100 plants of the same variety ful Orders for less than 500 plants accepted at the 100 postpaid price Express collect prices: 100 postpaid price. Express collect prices: 3000 plants (standard crate) $\$ 1.25$ per 1000 . Shipments start about October 1.

\section{BERMUDA ONION PLANTS}

Onion plants will stand heavy frosts and Yellow and Crystal White Wax Bermudas. Postpaid prices: 200 plants, 50c. 500 s1.00 1000 or more, $\$ 1.75$ per 1000 . No order for less than 200 plants of the same variety. Express collect prices: 1000 or more plants, $\$ 100$ per 1000; 6000 plants (standard crate) or more, $75 \mathrm{c}$ per 1000 . Orders for less than 6000 plants accepted at the 1000 price. Orders filled from October 1 to April 1.

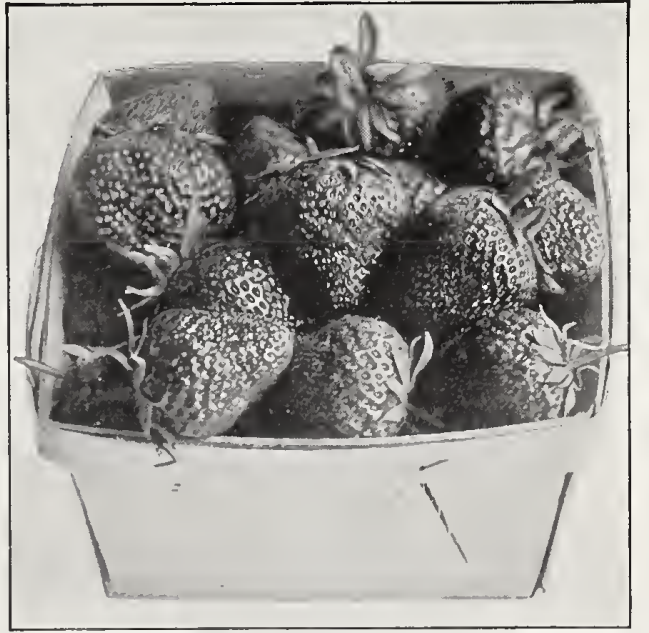

Improved Klondike Strawberries
STRA WBERRY PLANTS

All orders shipped direct from our grower's station in Arkansas.

Each plant has a strong root-system. Orders arc carefully packed, and we guarantee that perfect condition and that you will receive a full count. Plants shipped from October 1 to A pril nly. No C. O. D. orders accepted.

Mastodon. The most popular everbcarin variety. Very largc. Postpaid prices: 25 Express collect prices: 250 for $\$ 3.75 ; 500$ for New 1000 for si2.00; 5000 for $\$ 30.00$.

New Blakemore. Very firm bright red color and uniform shape. Splcndid market sort and superior for preserving. Postpaid prices: 25 plants $80 \mathrm{c}$; 50 for $\$ 1.10 ; 100$ for $\$ 1.75$. Express collect prices: 250 for $\$ 1.75$ Improved Klondike. A medium-sized sort very firm; deep crimson to center; acid. (Scc ted to Florida, Alabama, and South Texas. Lady Thompson. An early home sort. Postpaid prices: 25 plants $60 \mathrm{c} ; 50$ for $\$ 1.00$; 100 for $\$ 1.25$. Express collect prices 250 for $\$ 1.50 ; 500$ for $\$ 2.25 ; 1000$ for $\$ 3.50$ 5000 for $\$ 15.00$ 


\section{FLOWERS FOR FALL GARDENS}

We offer on the following pages a complete assortment of flowers | be listed and described in our Winter Garden Book, to be issued that may bc sown in southern gardens during summer and early October 1 . This book will also contain a full list of winter- and fall months. Select your favorite varieties from this list and cnjoy spring-flowcring bulbs, rose bushes, nursery stock, and winter a profusion of colorful, cxquisite blooms during the late summer and autumn months when gardens are ordinarily drab and bare.

Many of the fincst annuals and perennials do not thrive in the lawn grass.

If you wish a copy of Reuter's Winter Garden Book, we shall be pleased, upon receipt of your requcst, to place your name on Lower South, if planted during the summer. Such flowers will our mailing-list.

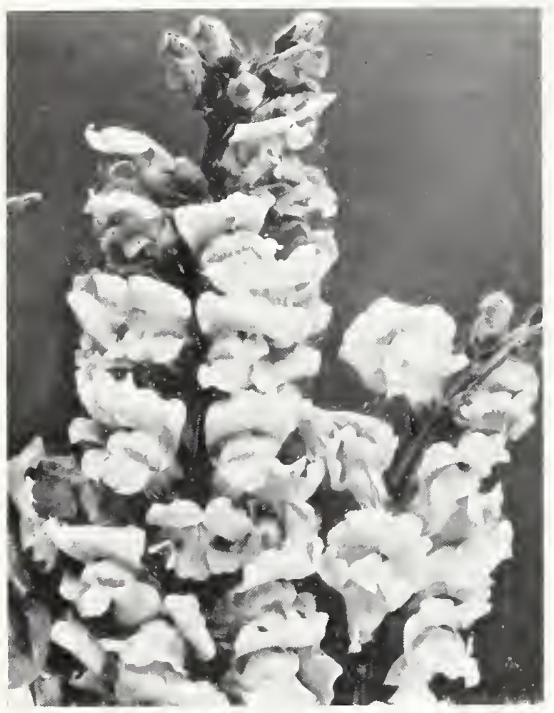

Giant-flowering Antirrhinum

\section{ALYSSUM (MADWORT)}

Splendid little annual for edging and bedding It is easy to grow and starts to bloom a few weeks
after planting. Sow July-October. Height 6 to 9 after p

1123 Little Gem. Dwarf, eompact grower thickly covered with

$10 \mathrm{c} ; 120 z .35 \mathrm{c} ;$ oz, 60c.
1125 Lilac Queen

Queen. Similar to Little Gem, but blooms. Pkt $10 \mathrm{c}$, $35 \mathrm{c}$; 1128 Saxatile Compactum (Basket of Gold) Perennial Alyssum with attractive golden yellow
blossums. Excellent rock-garden plant. Pkt. 10e $1 / 40 z .35 \mathrm{c} ; 120 \mathrm{z} .60 \mathrm{c}$.

\section{ANTIRRHINUM (SNAPDRAGON)}

For exquisite beauty few flowers equal the modern Snapdragons. They make glorious massed beds and Sow August-November. Height 2 to 3 feet.

\section{Tall, Large-flowering}

1148 Crimson King. Large; rich erimson.

119 Defiance. Fine orange-scarlet.

1152 Golden King. Giant yellow.

1156 Salmon-Pink. Desirable shade.

1158 Queen Victoria. Pure white.

All above: Pkt. 10c; 1/40z. 40c.

1153 Jennie Schneider. Rose-pink. Pkt. 25c.

1154 Mont Rose. Clear deep pink. Pkt. 20c.

1160 Finest Mixture. Super

1174 Tangerine. A strikingly showy new Snapdragon. The color is a frery orange of great

\section{Maximum or Giant-flowering} Strong growers with limmense spikes carrying

1166 Bunch of Lilacs. Lilac-purple.

1166 Bunch of Lilacs. Lilac-purple.

1168 Indian Summer. Copper-scarlet.

1168 Indian Summer. Copper-scarlet.

1170 Snowifake. Pure white with yellow tube.

1171 The Rose. Exquisite bright rose-pink.

All above: Pht. $15 c ; 1 / 80 z .50 c$.

1172 Maximum or Giant Mixture. Carefully

blended,

\section{ANCHUSA}

These provide some of the few really blue flowers for our gardens. The bloons are produced in sprays, partly shaded location. Sow August-November. Annual. Height $11 / 2$ feet. Pkt. 20c; $1 / 0 \mathrm{oz}$. 50c. Height 4 fect. Pkt. 15c; $1 / 10 z$. 40c.

\section{BALSAM \\ (LADY-SLIPPER)}

Greatly improved strain, with Iarge, waxv,
camellia-like blooms in soft and brilliant shade. and combinations. Sow the sced during July and August in a weIl-drained soil. Delight in a sunny location. Height 2 feet.

1245 Camellia-flowering Mixture. Very showy blend. Pkt. 10c; $1 / 2 \mathrm{oz} .30 \mathrm{c} ; 0 \mathrm{z} .50 \mathrm{c}$ $\begin{array}{ll}1246 \text { White } & 1247 \text { Rose } \\ 1248 \text { Scarlet } & 1249 \text { Purple } \\ 1250 \text { Yellow } & 2705 \text { Lilac }\end{array}$

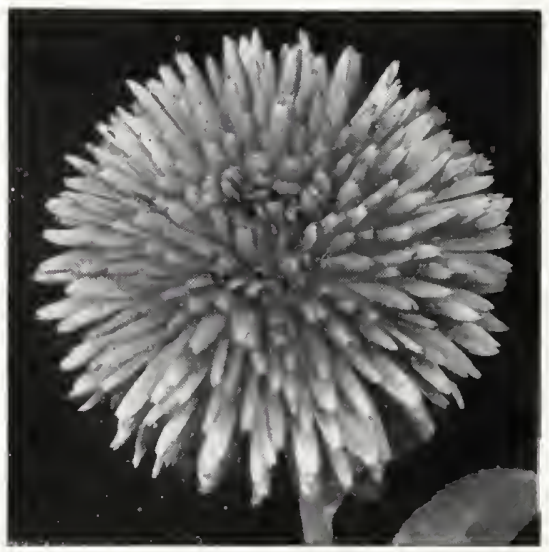

Calendula, Radio

\section{CALENDULA \\ (POT MARIGOLD)}

One of our most desirable fall flowers. They are of easy culture, very prolifie bloomers, and produce prized as cut-flowers. Sow August-October. Height

1253 Orange King. Showy, bright orange flowers. 1255 Lemon Queen. Identical to Orange King, except the color is a clear lemon-yellow. Pkt. $10 \mathrm{c}$ 1257 Ball's Orange. Exceptionally large, wellformed, scintillating golden orange flowers with

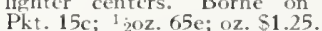

1258 Ball's Gold. Ilas the same good qualities as Ball's Orange. The color is an exquisite, dark 1260 Radiow. Pkt. $15 \mathrm{c} ; 1202.65 \mathrm{c}$; 02. distinct in form. The medium-sized blooms are robular shape, with brist Very beautiful and 1259 Senstion Calendula yet introduced. It is a vigorous grower, with enormous, double, flat, brilliant Pkt. 15c; 120z. 85c; oz, $\$ 1.50$.

Reuter's Winter Garden Book (Ready October 1)

Your copy will be mailed upon request

\section{CALLIOPSIS}

A lovely and graceful annual for beds and borders. The small, daisy-like flowers, in striking shades of crimson, orange, and gold, carried on bushy, wlants. Sueeed in almost any Iocation. lleight $1 \frac{1}{2}$ feet. Sow July-October.

1262 Dwarf Mixture. Very showy blend of bright and glorious eolors. Pkt. 10c; 1/20z, 25c; 126, 4 Marmorata. Rich golden yellow flowers, attractively marbled with wallflower-red. Pkt. 126,5 Crimson King. Deep crimson of velvety texture. Pkt, 10c; $1,10 z, 20 \mathrm{c} ; 1,20 z, 35 c$

\section{CANDYTUFT}

These delightful annuals may be grown with plendid success in fall. They furnish your bed and borders with masses of colors, and are highly September. Height 1 foot. 1286 Mixed Colors. WeIl blended. Pkt. 10c; $1 / 20 z .20 \mathrm{c} ; \mathrm{oz} .35 \mathrm{c}$. 1287 Lavender
1281 Crimson 1288 Flesh-Pink

Each: Pkt. 10c; $1 / 20 z, 25 \mathrm{c} ;$ oz. 40c. 1289 Hyacinth-flowered White. Finest white Candytuft, with immonse, pure white spikes,

\section{CORNFLOWER (RAGGED ROBIN)}

Well known to every flower-Iover. The sturdy plants carry an abundance of elegant, long-stemmed double flowers. Ilighly valuable for cutting. Good stems. Sow August-November. Herght $21 / 2$ feet. 1350 Double Mixed. (See illustration.) Pkt. 10c; 1351 Double White 1352 Double Pink 1353 Double Dark Blue 1354 Double Carmine Each: Pkt. 10c; 1/2oz. 30c; oz. 50c.

\section{COREOPSIS}

1390 Perennial with large, single, bright yellow flowers on Iong stems. Esteemed for cutting.
Sow September-November. Height 2 feet. Pkt. $10 \mathrm{c} ; 1 / 4 \mathrm{oz} .20 \mathrm{c}$

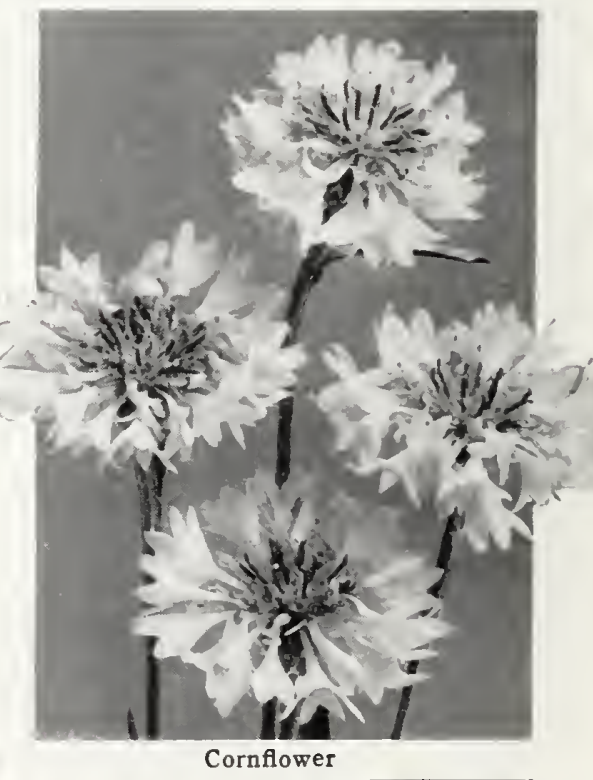

Flower Seeds 


\section{Make Your House COSMOS}

Delightful annuals fresh green foliage and large, artistic flowers produced freely throughout the season. Effective as a Sow during August and September. Height 4 feet. 1403 Klondyke. Very showy; golden yellow. Pkt

1406 Lady Lenox. Gigantic; deep pink. Pkt. 10c;

\section{Early Mammoth-Flowered 1408 White 1410 Pink 1412 Crimson 1415 Mixture}

Each: Pkt. 10c; $1 / 20 z .30 \mathrm{c} ; 0 z .50 \mathrm{c}$.

Early-Flowered Double Crested A Iovely Early-flowered Double Cosmos with similar to the single Cosmos, but the center is perfectly dcuble and beautifully crested. Produces a large percentage of double flowers. (See illustration.) 1418 Carnelia. Crimson. 1420 Peach Blossom. Pink. ( Each: Pkt. 20c; 1422 Whirlwind. White. $\} \begin{gathered}\text { Each: Pkt. } \\ 1 / 4 \text { oz. 75c. }\end{gathered}$ 1424 M

\section{CYNOGLOSSUM}

\section{(CHINESE FORGET-ME-NOT)}

1430 Delightful annual producing upright, graceful branches covered with small, single, forget-meSplendid for borders and cutting. Sow SeptemberSplendid for borders and cutting. Sow September-
November. Height 2 feet. Pkt. 10 c; 1 ;oz. 30c; oz. $50 \mathrm{c}$.

\section{SHASTA DAISY}

Showy perennisls with Iarge pure white marguer te-like flowers on long stems. Superb border plants, and excellent, long-lasting cut-flowers. Sow September-November. Height $2 \frac{1}{2}$ feet. 1470 Alaska. Immense tion.) Pkt. 10c; $1 / 40 z .50 \mathrm{c}$

\section{DELPHINIUM}

\section{(PERENNIAL LARKSPUR)}

Delphiniums produce tall, stately plants with immense, massive flower-spikes in indescribable, rich, and varied shades. Height 4 feet. Sow seed September-November.

1475 Reuter's Hybrids Mixed. Excellent strain. Pkt. 15c; $1 / 4 \mathrm{oz} .75 \mathrm{c}$

1477 Wrexham Hybrids. Remarkable new English Hybrids, with individual blooms, over 2 inches in diameter, exquisitely proportioned on tall, tapered flower-spikes. Very complete colorpurple, and violet. Pkt. $50 \mathrm{c}$.

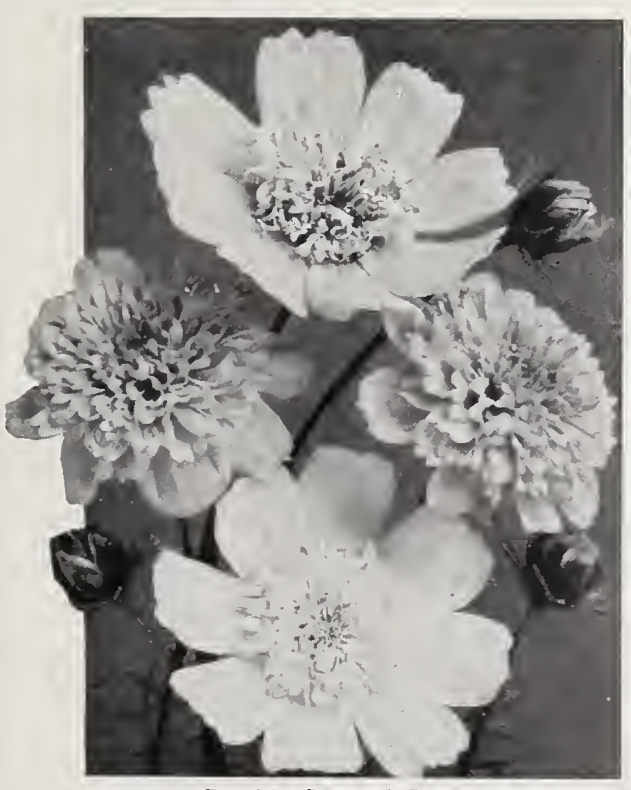

Double Crested Cosmos $1 / 2$ oz. $25 \mathrm{c} ;$ oz. $40 \mathrm{c}$

\section{a Home-Plant \\ DIANTHUS or PINKS}

This group embraces some of our most beautifu and best-loved flowers for bedding and borders. They are unsurpassed for striking colors and profuse flowers are of iragrant, oftcn delicately tringed sunny location. Easy to grow. Sow July-October. Height 1 foot.

1480 Chinensis, Mixed (Dcuble Chinese Pinks) Pkt. 10c; 1/20z. 40c; oz. 75c 484 Heddewigi Mixture (Single Japanese Pinks)
Lovely fringed flowers. Pkt. 10c; $1 / 20 z .35 \mathrm{c}$.

Double Japanese Pinks 1488 Fireball. Rich blood-red. 1489 Lucifer. Orangc-scarlet. 1490 Salmon King. Salmon-rose. Each: Pkt. 10c; $1 / 40 z .50 \mathrm{c}$.

1496 Cyclops. Beautiful, new, rock-garden plant, iterally covered with lovely, single, delicate tive, blood-red eye. Pkt. $25 \mathrm{c} ; 3$ for $65 \mathrm{c}$.

\section{GLOBE AMARANTH (BACHELOR'S BUTTON)}

A distinct and showy everlasting flower with pretty, smaIl, clover-like blossoms in purplish red, and borders. Sow July and August. Height 2 feet. 1542 Pink

1545 Mixed Colors

Each: Pkt. 10c; 1/40z. 20c; 1/20z. 30c; oz. 50c.

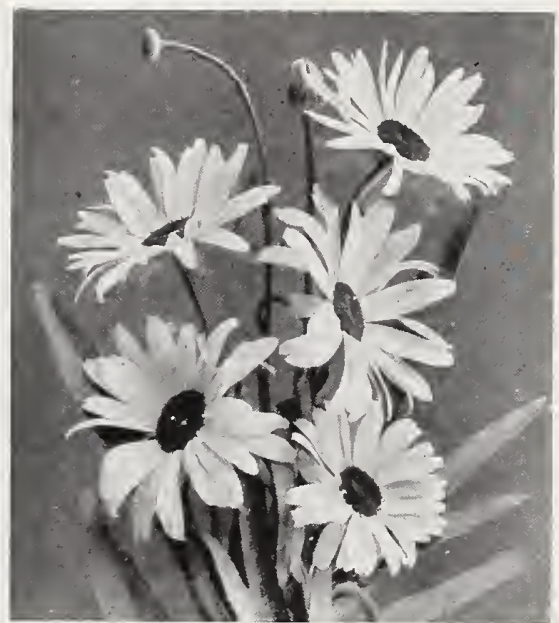

Shasta Daisies, Westralia

GODETIA

1560 Gladiolus-flowered grown hardy annuals highly prized for cutting and afford a magnificent display for beds and borders. They are upright, bushy growers with double, satiny blooms in a manner similar to the gladiolus. The color is a delicate shade of rose

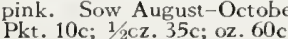

\section{GYPSOPHILA (BABY'S BREATH)}

\section{Greatly admired for their myriads of small,} dainty, single, star-shaped blooms, forming a charming misty effect. Fine bedding and borde cut-flowers. Make your first sowing in September. 1587 White 1590 Pink

Each: Pkt. 10c; $1 / 20 z .15 \mathrm{c}$; oz. 25c.

1591 Crimson. Showy new color. Pkt. 10

\section{LINUM}

\section{SCARLET FLAX}

1700 Dainty small annuals for beds and borders. The single, brilliant, scarlet-red flowers are carrie on slender stems. Very prolific bloomers. So

a Flower Garden

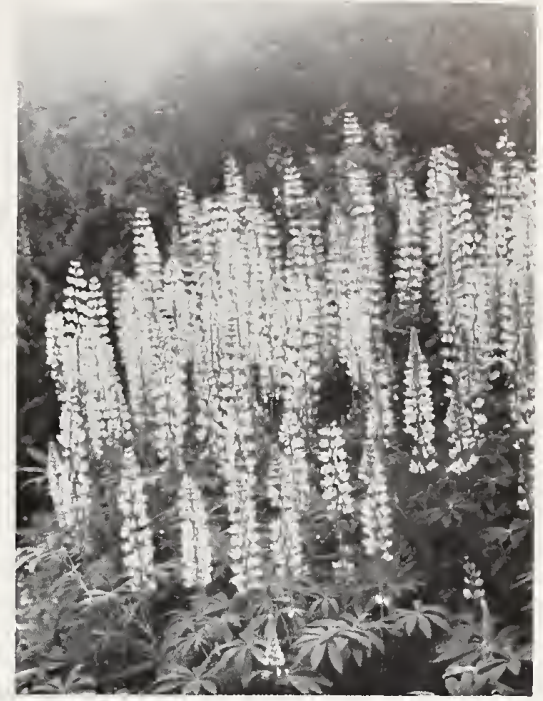

Perennial Lupins

\section{LUPINS}

Few flowers give garden as Lupins. They are very prolific bloomers and carry graceful, long-stemmed, pea-shaped and blue. Both the annual and percnnial varieties make wonderful beds and borders, and the graceful spikes are valuable for indoor decoration. Make 1600 Annual White 1694 Annual Sky-Blue 1692 Annual Rose 1695 Annual Mixed Colors Each: Pkt. 10c; $1 / 20 z .25 c ;$ oz. 40c.

1696 Yellow. Very popular sulphur-yellow. Pkt. 1697 Perennial Mz $85 \mathrm{c}$. (Polyphylus) Stately plants with immense decorative spikes. A gem tration.) Pkt. 10c; $1 / 20 z .25 \mathrm{c} ; \mathrm{oz} .40 \mathrm{c}$

\section{MATRICARIA \\ (DOUBLE WHITE FEVERFEW)}

1718 Showy plant for mixed bordcrs and cutting. It is an upright grower with fincly cut, dark green in terminal clusters Sow July and August. Height 2 fcet. Pkt. $10 \mathrm{c}$; $1 / 40 \mathrm{oz}$. 25c; $1 / 2 \mathrm{Oz} .40 \mathrm{c}$.

\section{MARIGOLD}

These well-kncwn, hardy, frce-flowering annuals enjoy a well-deserved popularity. The African group averages 3 feet in height and has uniforml large, denscly double flowers in yellow and orange
shades. The Frcnch typc is dwarf in growth, more the shades. Both are excellent for beds and borders and bloom profusely, May be sown during July, August, 1702 African Lemon 1705 African Orange Both: Pkt. 10c; $1 / 40 z .35 c ; 1 / 2$ oz. 65 c; oz. $\$ 1.20$ 1706 Alldouble Lemon 1707 Alldouble Orange Both: Pkt. 25c; 1/40z. $\$ 1.00$ 1708 African, Mixed. Pkt. $10 \mathrm{c} ; 1 / 20 z .40 \mathrm{c} ;$ oz. $75 \mathrm{c}$
1710 French Dwarf, Mixed. 1 foot. Pkt. $10 \mathrm{c}$ 1712 French Dwarf Pallida. Very shcwy; dwarf; $30 \mathrm{c}$ 1715 French Tall, Mixed. 2 feet. Pkt. 10c 1717 Guinea Gold. The sensational new Marigold. It is a distinct type of graccful, pyramidal flowers of brilliant orange color flushed gold. A very prolific bloomer and most desirable for bed and borders. As it is without the objectionable and lacks their pungent odor it has become favorite cut-flower. Hcight $2 \frac{1}{2}$ feet. Pkt. 50c;

Reuter's Winter Garden Book (Ready October 1)

Your copy will be mailed upon request 


\section{A Garden Is Appraised by the Quality of Its Flowers}

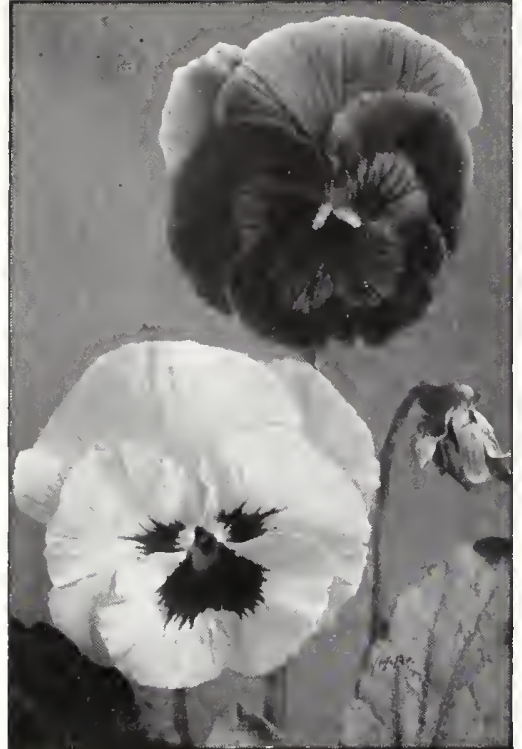

Pansy, Giant Trimardeau

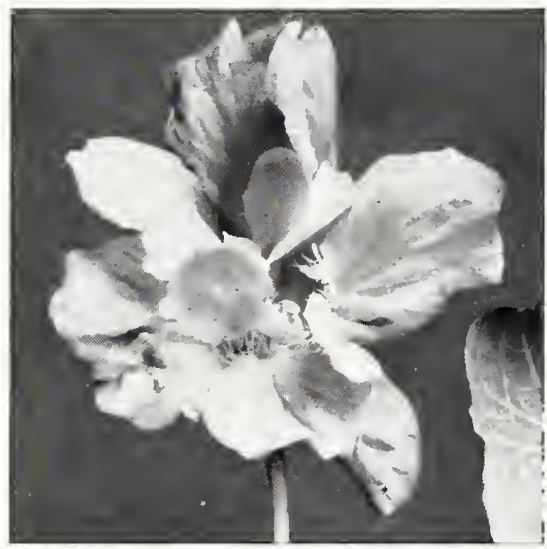

Nasturtium, Golden Gleam

\section{NASTURTIUM} amid a lush growth of round, bright green leaves, have for ycars commanded a position of prominence
in all flower-gardens. They are umequaled for casy eulture, brilliancy of blooms, and general excellence
Make your first sowing during the month Make your
September.

\section{Dwarf Varieties}

Form compact bushes about 1 foot high, and make the mo me

1750 Crystal Palace Gem. Sunflower-yellow, heavily spotted carmine.

(756en. Attractive salmon-rose. Darr-lenved

1757 Pearl. Creamy whitc. Each: Large pkt. 10c; oz. 20c; 1/4lb. 60c; lb. $\$ 1.75$ 1760 Large-flowered Dwarf, Mixed.

phl. Hoc; $0 z$. 15c; 1 lb. 40c; lb. $\$ 1.25$;

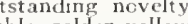
flowers average 2,2 to 3 inclies across, and ar about 6 inches in length. Delightefully swee

Tall Varieties

176,5 Large-flowered Tall, Mixed. Fine for Iow lences, porch- and window-boxes. Produee the

\section{GIANT PANSIES}

The exquisite beauty of the Pansies is well known to every lover of flowers. Strikingly beautiful in beds and borders, and delightful for indoor decoration in low bowls. Height 6 inches.

1785 English Mixed. A prolific bloomer with flowers of medium size. Pkt. 10c; 1/40z. 50c; 1788 Giant Trimardeau, Mixed. Particularly recommended for their hardiness, luxuriant and robust growth, and striking range of colors.
(Seeillustration.) Pkt. 15e; 1 . $02.60 \mathrm{c} ; 120 \mathrm{oz} . \$ 1.00$.

\section{Separate Colors}

1798 Pure White 1800 Red 1813 Purple 1803 Yellow 1806 Blue
Each: Pkt. 15c; 1/4oz. 70c.

1790 Giant Parisian, Mixed. An improved strain with large, blotched flowers of fine keeping

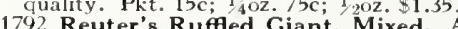

Reuter's Ruffled Giant, Mixed. A supersplendid texture, and the plants of robust growth, holding their majestic blcoms well above the foliage. The color combinations are 1795 Reuter's Peerless, Mixed. Magnificent mixture of extra-large regal flowers in a multitude of harmonious and enchanting eolors and shades.

\section{PETUNIA}

For freedom of bloom, variety of color and effectivencss, these annuals have no equal. Exrain. Planted, unanected by heat, drought, or and give an excellent display in porch-and window. boxes. Sow from July to October. Height 1 to

\section{Single Bedding Petunias}

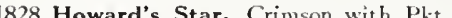
blush-pink star............. so 10 so 40 1830 Kermesina. Deep crimson.... 10 1831 Rose of Heaven. Brilliant rose. 1832-A Silvery Blue. Light blue.. 1833 Snowball. Satiny white.

1834 Violacea. Violet-blue ...... The

finest blend of dwarf, eompact va-
rieties. 1 1 oz.40e; $120 z .70 \mathrm{e} ; 0 z . \$ 1.25$

\section{Balcony Petunias}

1825 Blue 1826 Crimson 1827 Mixed Each: Pkt. 20c; $1 / 80 z .75 \mathrm{c}$. 1835 Reuter's Balcony Queen. I mmense, beau"Rathaus Petunia." Pkt. 25c.

2990 Star of California. Large, velvety flowers of violet color with conspicuous white blotches in eaeh petal, producing a very beautiful starred

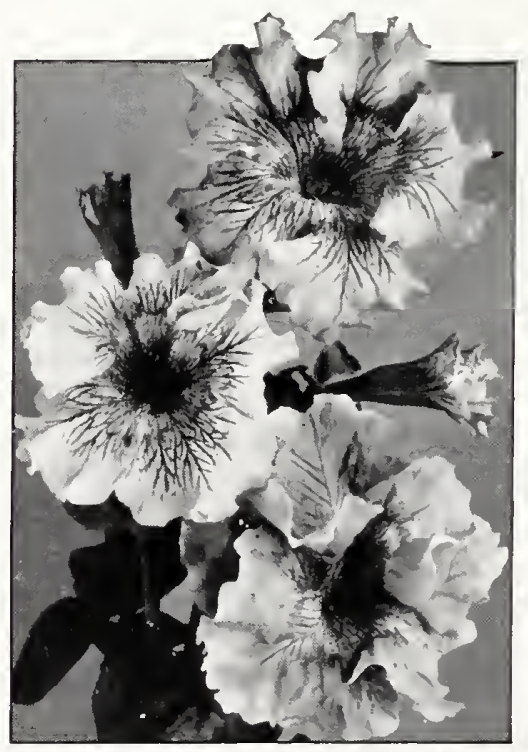

Petunia, Giants of California

\section{Giant-flowered Petunias}

\section{These are the amazing accomplishment of the} greatest flower-seed hybridizers who have created new and rare strains with immense blooms of tigered throats. Magnificent plants for porch-and window-boxes, and pots.

1822 Giants of California, Mixed Colors. Enormcus, veined flowers in attractive colors. 1823 Dwarf Giants of California, Mixed Colors. Magnificent, dwarf, cumpact growers, especially adapted for pot-culture and for bed1824 Fluffy Ruffles, Choice Mixture. Strong, robust growers with enormous flowers exquisitely ruflled. Embraces a glorious color-range. Pkt. 35c. of bright rose-pink color, with beautiful golden 2995 Steel-Blue. Attractive, deeply fringed Petunia of mammoth size. The eolor is a beautiful shade of steel-blue, with deeper blue throat heavily veined. The finest light blue Petunia. 18.40 Reuter's Giant Double Mixture. These brilliant Petunias produce giant, double, ballshaped flowers in many lovely colors and shades. Wateh the plants showing yellowish tint, as they produce the finest double flowers. Pkt. $35 \mathrm{e}$

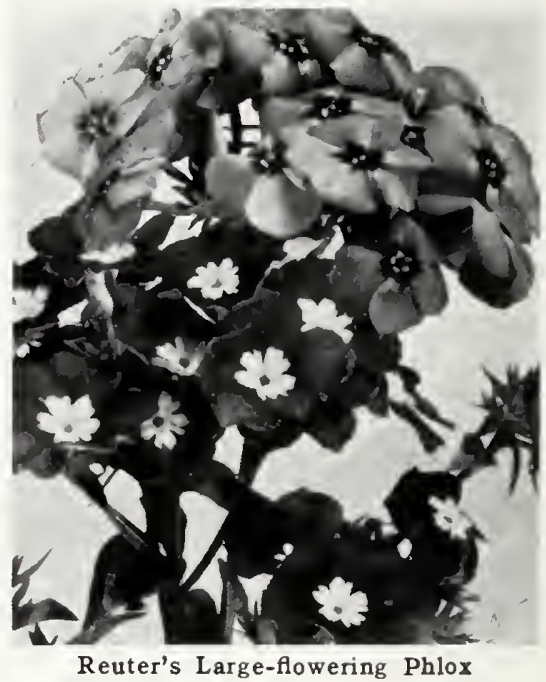

PHLOX

These marvelous annuals flourish in all their glory throughout the late summer and fall. The long-stemmed clusters of showy, round flowers are beautiful shades. Particularly attractive in massed Oedober.

\section{Dwarf Phlox}

Large-flowering dwarf, compact-growing type. 18+2 Mixed Colors. Well blended. Pkt. 15c; 2391 Pure White $\quad 2392$ Salmon-Pink 2393 Blood-Red 2394 Yellow Each: Pkt. 15c; 1/40z. 70c.

1814 Star Phlox, Mixed. Distinct type with ornamental, star-shaped howers in a large range

\section{Large-flowering Phlox}

perfecty rout hifh and produce extralarge, perfectly round llowers with overlapping 1845 Mixed Colors. Comprise the most out standing shades and brilliant colors. Pkt. 10c; 1848 Pure White 1850 Flesh-Pink 1851 Rose 1852 Chamois-Rose 1856 Scarlet 1857 Crimson Each: Pkt. 10c; $1 / 40 z .40 \mathrm{c}$.

1860 Hardy Perennial Mixed Colors. Do not confuse these with the annual Phlox. They form sturdy bushes about 2 feet high, with immense shades. New-crop seed ready in November. Pht. 20c; 1/40z. \$1.00. 


\section{Use Reuter's Flower Seeds and Enjoy the Finest Blooms}

\section{POPPY}

For gorgeous display, few flowers can compete with their large, bright, and dazzling blooms September-December for fall and winter blooming. 1865 Double, Mixed. Large, ball-shaped flowers Height $21 / 2$ feet. Pkt. 10e; $1 / 20 z .15 \mathrm{c} ;$ oz. $25 \mathrm{c}$ 1867 Double Pink 1868 Double Salmon 1869 Double Brilliant Rose

Each: Pkt. 10c; 1/2oz. 30c; oz, 50c.

1872 Rhoeas Shirley, Mixed. Single, in lovely pastel and brighter shades. Height 2 feet. Pkt. 10c; 1/20z. 20c; oz. 30c.

3025 Begonia-flowered Sweet Briar. Delightful new Poppy in the popular Shirley group with fully double flowers resembling a large, double begonia in bloom. The color is a beautiful rose pink. Fine for cutting. Pkt. 25c; 3 for 65c. Planders. Single, scar of Flanders. Height 1 foot. Pkt. 10c; $1 / 20 z .25 \mathrm{c} ;$ oz. $40 \mathrm{c}$

1875 Iceland, Mixed. Dainty perennial with single white, yellow, and orange flowers. Height Single white, yellow, and orange
15 inches. Pkt. 10c; $1 / 40 z, 40 \mathrm{c}$.

1878 Oriental. Showy perennial of strong, bushy growth, with immense, single, deep crimson

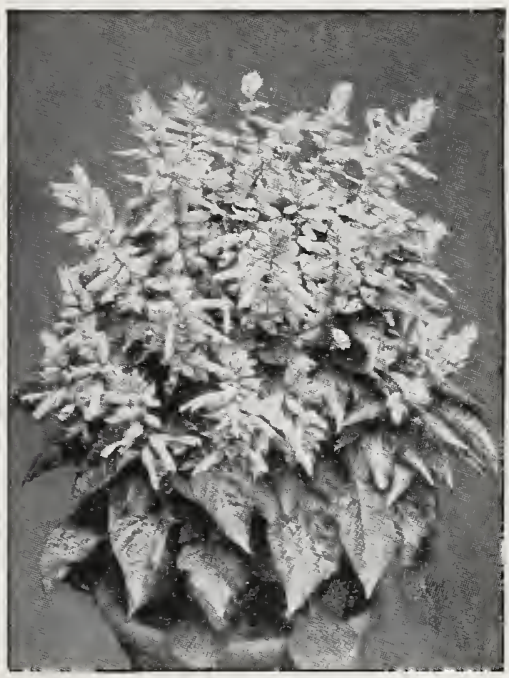

Salvia, Harbinger

\section{PORTULACA}

(SUN PLANT)

This gay little annual is a dwarf, creeping grower with glossy, single, eup-shaped or double rose-like flowers in a dazzling display of riehest eolors. Prefers a light sandy soil and a sunny exposure. Sow in July and August. Height 6 inehes.

1880 Single, Mixed. Fine large-flowering blend. Pkt. 10c; $1 / 20 z .25 \mathrm{c}$

Very fine, selected strain Pkt. 10c; $1 / 4 \mathrm{oz} .65 \mathrm{c}$

\section{SALVIA}

(SCARLET AND BLUE SAGE)

Brilliant perennials unrivalcd for massing in beds and borders. Easily grown, doing well in any Sow August-Nover,

1905 Splendens. Bright scarlet. Height 2 feet. Pkt. 10e; $1 / 4 \mathrm{oz} .75 \mathrm{c} ; 1 / 2 \mathrm{oz} . \$ 1.35$.

1906 Bonfire. Magnificent early-flowering Salvia. It is a dwarf, compaet grower, with dazzling scarlet flower-spikes raised clear above the
foliage. Height $11 / 2$ fect. Pkt. 20c; $1 / 40 z$. $\$ 1.00$ $1 / 20 z$. $\$ 1.75$.

1907 Harbinger. Most striking of all bedding Salvias. The plants are of symmetrieal, dwarf, bright scarlet flower-spikes are uniformly and sufficiently raised above the foliage to eover it as a blazing blanket. Height $\mathbf{1}$ foot. (See illustration.) Pkt. 25c;3 for $70 \mathrm{c}$.

1908 Azure-Blue. Deep azure-blue. It is a taller grower than the red-flowered types and is
largely used for planting in mixed borders. largely used for planting in mixed borders.
Height $21 / 2$ feet. Pkt. 20c; $1 / 4 \mathrm{oz}$. $\$ 1.00 ; 1 / 2 \mathrm{oz}$. $\$ 1.75$

Flower Seeds

\section{SWEET PEAS}

These lovely climbers are easily grown and highly prized for garden as well as indoor decoration. When you order, ask for our booklet "The

\section{Early-flowering Spencer}

The ideal Sweet Peas for late summer and fall planting. Will begin blooming about seven weeks after planting, and produce a mass of flowers until By freezing weather.

2601 Blue Bonnet. Deep, clear blue. 2605 Blue Sensation. Large; light blue. 2613 Exquisite. Salmon, tinted orange. 2621 Giant Rose. Giant; rose-pink. 2628 Harmony. Large; clear lavender. 2636 Mrs. Kerr. Lovely salmon shade. 2640 Oriental. Deep cream. Black-seeded. 2648 Perfection. Giant; dark rose.

2656 Springsong. Salmon, suffused eream. 660 Vulcan. Scarlet. Does not bur.

All above: Pkt. 15c; oz. 50c; 1/4lb. \$1.75 2662 Sweet Pea Collection: 1 pkt. each of the 10 above varieties for $\$ 1.00$.

2609 Empress. Giant; light pink.

2617 Fortyniner. Glorious bright orange. 2632 Michigan. Mammoth; pure lavender. 2644 Pal. Large; rich rose-crimson.

White Harmony. Large; pure white. All above: Pkt. 15c; oz. 65c; 1/4lb. $\$ 2.25$ 2145 Early-flowering Spencer Mixed. liste $\mathrm{J}$ above, and many others. Pkt. 10c; oz. $40 \mathrm{c}$; $1 / 4 \mathrm{lb}$. $\$ 1.25$; Ib. $\$ 4.00$.

Two New Early Spencer Sweet Peas 2625 Greeting. Extra long-stemmed, giant Pea of elearest lavender color. (See illustration.)
2652 Pride. A glorious pure cerise, with delicately frilled, mamnoth flowers on long stems. Each: Pkt. 20c; 1/20z. 60c; oz. $\$ 1.00$

Late Spencer or Orchid-flowered

This type is hardier than the early-flowering, and is reeommended for late fall planting. The blooming the following spring. Make your first sowing in September.

2010 Austin Frederick. Giant; Iavender.

2015 Constance Hinton. Pure white.

2018 Crimson King. Ox-blood-erimson.

2020 Elfrida Pearson. Blush-pink.

2022 George Shawyer. Orange-pink.

2023 George Shawyer. Orange-pink.

2024 Hawlmark Cerise. Cerise-salmon.

2025 Heavenly Blue. Delphinium-blue.

2026 Hebe. Immense; bright pink

2028 Mary Pickford. Pink, tinted salmon.

2032 Pinkie. Magnificent giant rose.

2040 Royal Purple. Fine purple color.

2038 Royal Scot. Bright scarlet.

2041 Tangerine. Brilliant orange.

Prices on all: Pkt. 10c; oz. 25c; 1/4lb. 75c; 1b. $\$ 2.50$ 2048 Late Spencer or Orchid-flowered Mixture. A glorious mixture of prize-winning varieties $10 \mathrm{c} ;$ oz. $25 \mathrm{c} ; 1 / 4 \mathrm{lb}$. 75e; Ib. $\$ 2.00$.

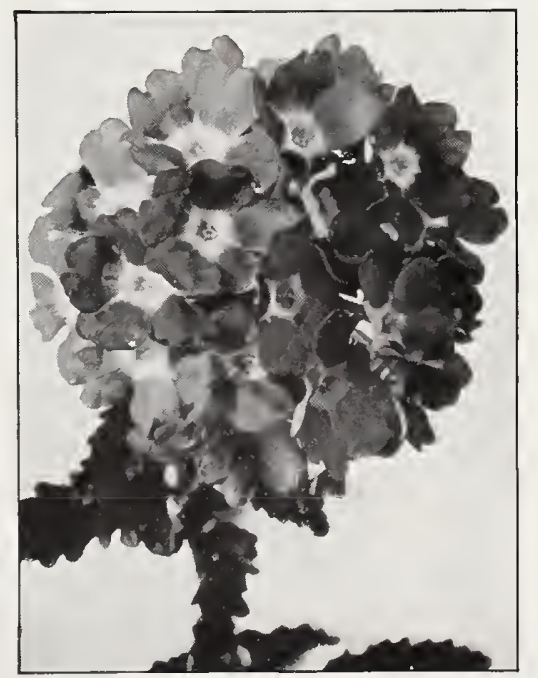

Verbena, Lavender Glory

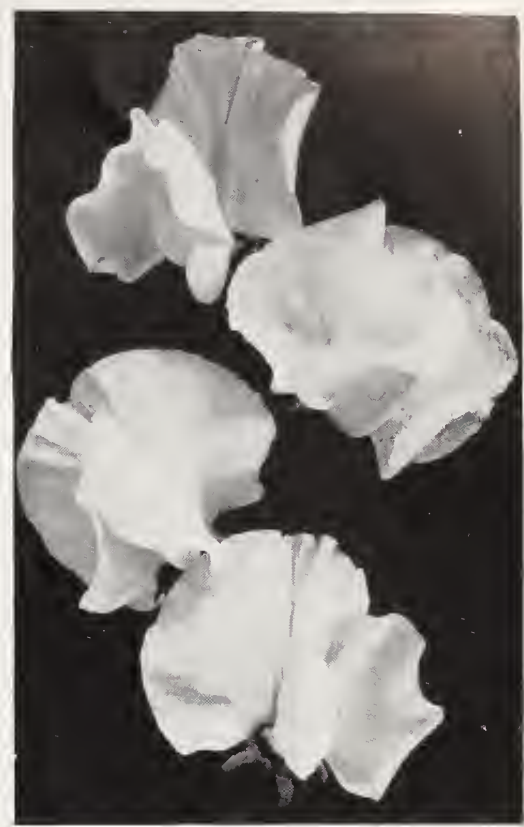

Sweet Pea, Greeting

\section{SWEET WIVELSFIELD}

3040 Fine, new, hardy annual of bushy growth. produeing a continuous mass of single round, delight the most diseriminating garden owner. Does best in a sunny, well-drained locatiorr. Sow Height 1 foot. Pkt. 35c; 3 for $90 \mathrm{c}$

\section{MAMMOTH VERBENAS}

Free-flowering, half-hardy, graceful annuals of spreading growth, with somber, dark green foliage covered with glorious, large, umbrella-shaped trusses of single flowers in a delightful range of border plants. Sow July-September. Height 1 foot. 2070 Reuter's Mammoth Mixture. Includes all found in the popular Verbenas. Pkt. $10 \mathrm{c}$ $1 / 40 \mathrm{z} .45 \mathrm{e} ; 1 / 2 \mathrm{oz} .80 \mathrm{e} ; \mathrm{oz} . \$ 1.50$.

2072 White
2074 Striped

$2076 \mathrm{Red}$ 2075 Blue

Each: Pkt. 10c; 1/40z. 50c.

3055 Golden Queen. Attraetive golden yellow, a new and distinet color in Verbenas. Pkt. 25c

Reuter's Giant-flowered Verbenas. A glorious 2080 Pure White

2081 Rose-Cardinal. Rose-pink, white eye.

2082 Lucifer. Vivid scarlet self.

Each: Pkt. 20c; $1 / 40 z .75 c$.

3050 Lavender Glory. Immense blooms in large, well-formed trusses. The eolor is a true lavender with medium size, creamy white eyes. A new 3 for $\$ 1.3$

084 Giant-flowered Mixture. Well-balanced blend. Pkt. 15c; 1/40z. 60c.

Bouquet. An attr. distinct, tall and erect type producing plants of foliage and extra-largc flowers earried in elusters colors, nearly all with a distinct creamy eye Pkt. 25c; 1/40z. $\$ 1.00$.

\section{VINCA}

Free-flowering bedding plants of sturdy, bushy growth, with luxuriant, dark green, glossy leaves in lange, single, round, hive 2086 White 2089 Pink with dark eyes Each: Pkt. 10c; $1 / 40 z .40 c ; 1 / 20 z .75 c$.

2092 Mixed Colors. Pkt. 10c; $1 / 4 \mathrm{Oz} .35 \mathrm{c} ; 1 / 2 \mathrm{Oz} .60 \mathrm{c}$.

\section{ZINNIA}

Described and illustrated on the baek cover. 


\section{GRASS, FARM, AND FIELD SEEDS}

Market prices on Grass, Farm, and Field Seeds are subject quantities. Last-minute quotations will be found on the baek of to frequent ehanges. On this page, therefore, we give only re- the order sheet in the back of this Catalog. For more current Iiable descriptions of our seed-stocks and postpaid priees on small priees we suggest you write us, first stating quantities desired.

\section{GRASS}

829 Bermuda Grass. The most dependable and most permanent grass for lawns, goll-courses, makes a tough, even, elumpless turf that recovers preparer ground at the rate of 15 to 20 pounds per
acre for pastures and 30 to 40 pounds per acre for lawns. Cover very lightly. Pkt. 10c; 1b. 50c; 2 Ibs

830 Carpet Grass. Unexeelled for lawns and permanent pastures because of its ability to make a good growth on poor, sandy soils. Uselul on fair-
ways, landing-fields, lawn-tennis courts, and public park lawns. Thrives best and makes a thicker, Lespedeza and Burr Clover, it makes a fine allnot fall below 10 degrees. Easily eradicated by to the aere and for broadcast 15 to 20 pounds Pkt. 10c; lb. 40c; $2 \mathrm{Ibs}$. $70 \mathrm{c} ; 5 \mathrm{Ibs}$. $\$ 1.50$, postpaid.

\section{ALFALFA}

702 Hairy Peruvian. Best type for the South. Leaves and stems are quite hairy, giving plants a
slightly gray cast. The crowns are more ereet, have fewer stems, and are eoarser than ordinary weather when other Alfalfas have eeased and withstanding 10 degrees Fahrenheit or less before
it winter-kills. For hay, cut when not more than half in bloom. Plants reeover quickly after being per acre than regular types. Sow at the rate of 20 to 25 pounds per acre during the fall and early spring.
Pkt. 10c; lb, 40c; 2 lbs. 70 e; 5 lbs. $\$ 1.50$, post paid.

\section{The Original Legume Inoculator}

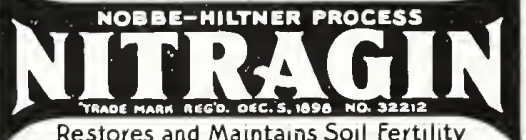

Restores and Maintains Soil Fertility

Nitragin contains millions of nit rogenfixing bacteria which, when properly legume plants. These bacteria gather nitrogen from the air and feed it to the crops,

Succeding crops are also benefited b nodules after the legume crop is harvested or plowed under.

blanting-time. It cannot harm crops, soil, or live-stock. Requires no skill or various legumes listed. Be sure to state the kind of legume seed you wish to inoculate.

\section{Alfalfa and All Clovers}

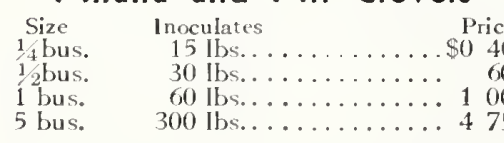

Peas, Vetch, Austrian Winter Peas, and Beans

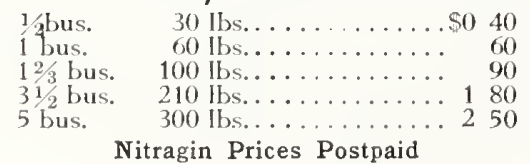

\section{GARDEN NITRAGIN}

Inoculates from 1 ounce to 8 po
Beans, Peas, or Sweet Peas, $25 \mathrm{c}$.

\section{CLOVER}

739 Crimson Clover. This variet y will grow Where other Clovers fail. It thrives on any welldrained soll, produeng a good, growth during the valuable winter cover-crop and protects the soil South it may be sown from July to November. broadcasting at the rate of 20 to 25 pounds per aere and followed by a light harrowing. Crimson ith grain such as rye, wheat barley, or winter s. Pkt. 10c; Ib. 35e; 2 Ibs. 60e; 5 lbs. \$1.25, ppd. 734 White Dutch Clover. Exeellent for lawns and pastures, and especially so when grown in and compact. When sown alone, use 10 pounds to the acre. May be planted either in the fall or spring.
Pkt. 10e; Ib. 65c; 2 lbs. $\$ 1.25 ; 5 \mathrm{lbs}$. 2.50 , postpaid. 737 Red Clover. Used for pasturage or soilimprovement. Produces two or more erops a season, 12 to 15 pounds per aere. Pkt. 10c; Ib. 50e;
using 2 a 90 ; 5 Ibs. $\$ 2.00$, postpaid.

736 Alsike Clover. The best variety for wet land. Does well in the Central South. Plant 10 to 12 pounds to the aere during the fall or early spring.
Pkt. $10 \mathrm{c}$; Ib. $50 \mathrm{c} ; 2 \mathrm{lbs}$. $90 \mathrm{e} ; 5 \mathrm{Ibs}$. $\$ 2.00$. postpaid.

735 Sweet Clover, White Blossom. Splendid soil-builder, for pasture, forage crop, or enfall or spring. Pkt. $10 \mathrm{c}$; Ib. 30c; 2 lbs. 50e; 5 Ibs. $\$ 1.10$, post paid.

738 Sweet Clover, Yellow Blossom. Extensoil-builder. Fall-sowing is best, using 15 to 20 pounds per aere. Pkt, $10 \mathrm{c}$; $1 \mathrm{~b}, 25 \mathrm{c}$; 2 lbs, $45 \mathrm{c}$;

740 Bur Clover. Exeellent for mixing with other Clovers and grasses when planting permanent pastures. It is an annual Icgume, coming from sced in burr, use 50 to 80 pounds per acre. Un-
hulled: Pkt. $10 \mathrm{e} ; 1 \mathrm{~b} .30_{\mathrm{c}} ; 2 \mathrm{lbs} .50 \mathrm{e} ; 5 \mathrm{lbs}$. $\$ 1.25$, postpaid. Hulled: Pkt. 10c; Ib. $35 \mathrm{c} ; 2$ Ibs. $60 \mathrm{c}$;

\section{GRAINS}

770 Red Rustproof Seed Oats. The best heavy vielding, rustproof Oats for the South. Our Louisana- and Mississippi-grown stock mav be planted
in the fall and harvested sufficiently early to allow the planting of another crop, sueh as peas or sorghum, on the same aereage. Oats is a good cover $20 \mathrm{c} ; 3$ Ibs. $50 \mathrm{c}$, postpaid.

777 100-Bushel Oats. One of the best strains of heavy-yiclding, rustproof Oats for this seetion. Ours is extra-heavy, plump seed of the highest
quality. Planted carly in the fall, it grows of quiekly and has proven almost as hardy as Rye.
It stools out strongly and makes the best kind of winter and early spring grazing for all
live-stock. Lb. 20c; 3 lbs. $50 \mathrm{c}$, postpaid.

775 Winter Rye. A strictly winter type and perfectly hardy, Our stock is southern-grown and Northern-grown seed will not produee sat isfaetorily. Makes a winter pasture-erop that is well appreciated
by farmers, dairymen, and stoek-raisers. Sow 11 to 1. bushels to the acre. Lb. $20 \mathrm{c} ; 3$ Ibs. $50 \mathrm{c}$, pos
paid. Abruzzi Rye. This variety is ideally
776 . This adapted to eultivation in the South. It stools
more quickly and is heavier, providing approximately twice the grazing produeed by other types. Can be pastured fully a month carlier that 779 Bearded Barley. Our seed is southerngrown and has been thoroughly releaned in our and is equal to them as a farl than rye or wheat Makes an exeellent pasture, and is desired by poultry raisers for winter green-feed and grazing. If grain, thus making it a dual-purpose crop. Nake a good nurse-crop, does not stool as mueh as oat seldom lodges, and forms so little shade that it will not injure a meadow. Broadeast 2
acre. 1.b. 20c; 3 lbs. $50 \mathrm{c}$, post paid.

773 Red May Wheat A beard

head variety that has the distinct adva or smoothsouthern conditions of being more suitable for feeding purposes. It is early, stiff, long, in straw, satisfaetory hay, Lb. $20 \mathrm{c}$; 3 lbs. $50 \mathrm{c}$, postpaid.

\section{MISCELLANEOUS}

876 Dwarf Essex Rape. An appetizing and nutritious pasture erop for stock and poultry. grazing nothing equals Dwarf Essex Rape. Grows turnips or on any soil that will produce a crop of for 2 months. After the plants have been cut or rutabagas, but larger, and are acceptable as table "greens." Plant has no bulbous roots. Should be sown at intervals from August until April, either pounds to the acre) Average yield is 10 to 15 tons per acre. Pkt. 10c; Ib. 25c; 2 lbs. 45c; 5 Ibs. \$1.00,

809 Austrian Winter Peas. A remarkable, heavy-yielding, winter legume whieh will thrive good hay; is excellent for torning under. A good winter crop, and a fine soil-improver. Sow 25 to $45 \mathrm{c} ; 5 \mathrm{lbs}$. $\$ 1.00$, postpaid.

741 Winter or Hairy Vetch. This is a satis. factory substitute for Clover in seetions where on poor land. It is a wonderful nitrogen gatherer and soil-improver. Stock relish it, and fatten on it. It is very hardy and is reeommended as a winter
cover-erop. Makes good hay when planted with rye, oats, or wheat to hold it upright. As a fall erop it should be sown during August and September at the rate of 40 to 50 pounds to the aere. Pkt. 10c;
lb. $30 \mathrm{c} ; 2 \mathrm{Ibs}$. $50 \mathrm{c} ; 5 \mathrm{lbs}$. $\$ 1.25$, postpaid.

808 Canada Field Peas. A valuable winter soil-improver. Good for plowing under as a green Attains. Should be sown in Oetober and November. when 6 to 10 inehes high. May be used in mixture with oats, barley, or wheat. When used alone,
broadcast 75 pounds to the acre. Pkt. $10 \mathrm{c} ; 1 \mathrm{~b}$. 30c; 2lbs. 50 e; 5 lbs. $\$ 1.25$, postpaid.
lat.

\section{DUBAY
SEED DISINFECTANTS SEMESAN

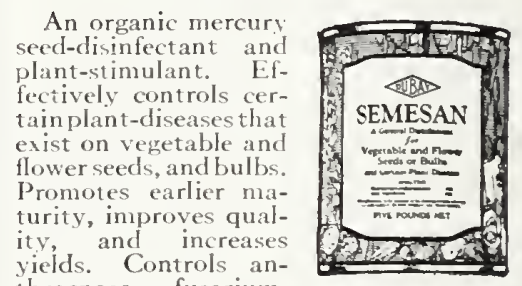

thracnose, fusarium,
rots, blight, rust, scab, wilt, mildew, damping-off, smut, and other diseases. Can be used as a dust or as a liquid. $25 \mathrm{lbs} . \$ 56.25$

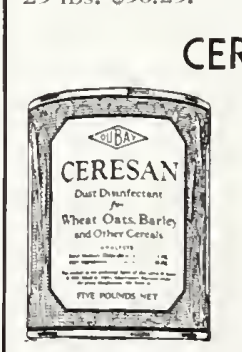

\section{CERESAN}

NU GREEN. An effective treatment for 3 ozs. $50 \mathrm{e} ; \mathrm{Ib}$. $\$ 2.00 ; 5 \mathrm{lbs}$. $\$ 9.00 ; 25 \mathrm{lb}$. $\$ 37.50$.

DuBay Products Cannot Be Mailed 
GENERAL

\section{INSECTICIDES}

Articles prefixed $(*)$ cannot be mailed. Customer pays transportation.

*Aphine. Kills green, black, and white flies, red spider, slugs, ants, thrip, mealy-bug, and scale. Used extensively
$\$ 1.00$; gal. $\$ 3.00$.

*Arsenate of Lead. (Powder.) Effective spray for leaf-eating insects. Does not burn the foliage. *Black-Leaf 40 (Nicotine Sulp

forcellent for killing aphis, thrip, sucking insccts, leaf-hoppers,
and poultry-lice. Oz. 35c; 5 ozs. $\$ 1.00 ; \mathrm{Ib}$. $\$ 2.25$;
2 Ibs. $\$ 3.35 ; 5 \mathrm{Ibs} \$ 6.25 ; 10$ Ibs. $\$ 10.75$.

2 lbs. $\$ 3.35 ; 5$ lbs. $\$ 6.25$; 10 lbs. $\$ 10.75$.
$*$ Bordeaux Mixture. (Powder.) Controls black rot, blight, rust, mildew, and other fungous diseases.
Stimulates plant-growth. Lb. 35c; 4 lbs. 85c; Stimulates plant-
100 lbs. S14.00.

*Calcium of Arsenate. (Powder.) Controls chewing insects on potatoes, yegetable cotton, and certain fruit trees. L.b. 20c; 4 bs. 50c; $100 \mathrm{lbs}$. $\$ 8.00$. wich controls plant-lice, thrip, red spider, leafwhich controls plant-lice, thrip, red spider, leaf8 ozs. $\$ 1.25$; lb. $\$ 2.25 ; 2$ lbs. $\$ 3.25 ; 10$ lbs. $\$ 12.00$,

postpaid. spraying of fruit and shade trees and bushes curl, and brown rot of peaches. Lb. 35 c; 5 Ibs. $\$ 1.50$;

*Dutox. (Powder.) Safe and non-arsenical. Will not injure plants nor impair the fertility of the not injure plants nor impair the fertility of the
soil. Controls Mexican bean beetle, tobacco hornworm, tomato-, cabbage- and cut-worms. Lb. 35c;

Ever Green. (Non-poisonous.) Kills both chewing and sucking insects. Will not injure or discolor the most delicate plants or blossoms, yet bean beetle. Oz. $35 \mathrm{c}$; 6 ozs. $\$ 1.00 ; 16$ ozs. $\$ 2.00$, postpaid. Not prepaid: qt. \$3.50; gal. \$11.50;

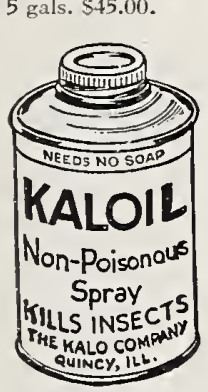

Kaloil. Non-poisonous, freeflowing liquid Pyrethrum spray which needs no soap. Thor film especially deadly to sucking insects such as aphis (plant-lice), leaf-hoppers, red mites, etc. $1 \frac{1}{2}$ ozs. $35 \mathrm{c} ; 6$ ozs.
$\$ 1.00 ; 32$ ozs. $\$ 3.50 ;$ gaI. $\$ 11.75$ postpaid.

Kalite. Quick-killing, nonarsenical dust which control chewing insects on vegetables, especially cabbage-worms, beeical and adheres well. Lb. $35 \mathrm{c}$ prepaid: $25 \mathrm{Ibs}$. $\$ 5.00 ; 100 \mathrm{Ibs}$ prepaid: 25 Ibs. $\$ 5.00 ; 100 \mathrm{Ibs}$

Kalo Spray, Non-arsenica powder fo

Kalo Spray: Non-arsenical powder for controlling eating insects on vegetables, flowers, and
fruits (including apples and peaches). Can be mixed with Kaloil and fungicides containing no free lime. One pound makes 50 gallons of spray. 300 ibs. $\$ 81.00$

*Nicotine Pyrox. A truly complete spray. Kills *Nicotine Pyrox. A truly complete spray. Kills both chewing and sucking Insects and controls plants. 10 ozs. (makes 2 gallons of spray) $50 \mathrm{c}$

* Pyrox. Kills all leaf-eating insects and prevents to the foliage. Mlixes easily and adheres well. to the foliage. M1.75; 10 Ibs. $\$ 3.00 ; 25$ lbs. $\$ 6.25$;

Sheps Spray. (Non-poisonous.) Gives positive protection against both chewing and sucking Benefits soil and foliage. 2 ozs. $35 \mathrm{c} ; 8$ ozs. $75 \mathrm{c}$; pt. $\$ 1.25$; qt. $\$ 2.00$; gal. $\$ 6.35$, postpaid.

sait-M. Effctive for controlling cut-worms, slugs, snails, grasshoppers, etc. Broadcast on plants. Water does not reduce its activity. Lb. 35c;

*Target Scale Destroyer. Dormant spray for white fly. A soluble oil that mixes well. Qt. 70c; gal. $\$ 1.50 ; 5$ gals. $\$ 6.50$.

Tobacco Dust. Kills aphids and flea-beetles Extra-frne grade. Lb. 20c; 5 Ibs. $75 \mathrm{c}$, postpaid.
Not prepaid: 10 lbs. $\$ 1.00 ; 25$ lbs. $\$ 1.50 ; 50$ lbs. $\$ 2.25 ; 100 \mathrm{lbs}$; $\$ 1.00$; 1000 lbs. or more $\$ 3.50$ per

100 lbs. scale, insects, white fly and aphis. Does not dis color foliage. 1/2pt. 35c; pt. 60c; qt. $\$ 1.00$; gal.

*Weed Killer. Exterminates weeds, grass, and noxious growths. One gallon makes 40 gallons.
Qt. 75c; gal. $\$ 1.75 ; 5$ gals. $\$ 6.75$.

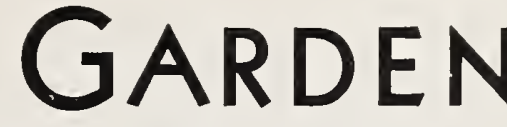

\section{SPRAYERS}

Purchaser pays transportation on the following items, except where postpaid prices are quoted.
Hudson Climax. Provides all the desirabl
features of a highpressure, com-
pressed-air Sprayer at a minimum cost Complete with 12 inch curved brass extension. Shipping
weight, 10 pounds.

Brass, \$6.00.
Hudson Junior.

Hudson Junior.
A strongly con-

structed compressed-air pacity $21 / 2$ gallons). Idcal for the home-garden. ComShipping weight, 9 pounds.
Galvanized, 54.50 ; Brass, $\$ 7$

\section{Hudson, Perfection,}

best high-pressure, compressed

air Sprayer. Tank made of gal vanized copper alloy or selcc
brass. Capacity, 4 gallons. Ship-

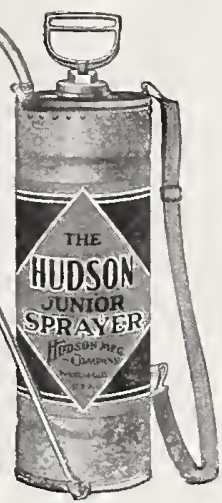

ping weight, 121 \% pounds. Galvanized, $\$ 6.50$; Brass, Brown's Special. 12 -inch Extension, 24 -inch Extension, 75 c. Brown's Special. A strong, single-action atomizer with heavy tin
1 quart. $50 \mathrm{c}$, postpaid.

Hudson Misty. Popular for use in the house, garden, and chicken-house. Constructed of heavy Critic Cacity, 1 quart. $40 \mathrm{c}$, postpaid.

Critic. (Continuous.) Pump of hcavy tin and tank of glass. Brass tip and tank top prevents Knapsack. (Meyers.) Conveniently shaped and
Knasion. Holds 1 quart. $\$ 1.00$, postpaid. equipped with shoulder-straps for carrying on back. Recommended for large gardens and truck-
farms. Capacity, 5 gallons. Shipping wcight, 17 pounds. Galvanized, $\$ 11.00$; Brass, $\$ 15.00$. pressed-air Sprayer with brass extcnsion. Capabl of handling all spraying solutions. Galvanized tank. Capacit

Ace, Sr. A new type, and most efficient, con tinuous Sprayer. Handles all kinds of spraying
solutions. Tank made of glass. Nozzle and tube solutions. Tank made of glass. Nozzle and tube
are brass. Capacity, 1 quart. $90 \mathrm{c}$, postpaid.
Ace, Jr. Same construction and style as Ace, Ace, Jr. Same construction and

Hudson Vapor. A handy little Sprayer for houschold use. Substantially built; suitable for all

\section{DUSTERS}

American Beauty. The best one-man Duster. high trees and large, bushy vines. Easily filled. Holds 15 pounds. Shipping weight, 18 pounds. Brown's No. 1. Small Duster well adapted to Brown's No. 1. Small Duster well adapted to
use in houses and small gardens. Useful in dusting Brownes. 55c, postpaid.

new type Duster that is

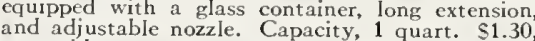

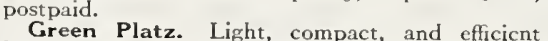
Green Platz. Light, compact, and efficicn
bellows Duster. Easily regulated. Excellent for hill crops, or reaching under-side of foliage. $\mathrm{Ca}-$
pacity, 2 to 4 pounds. Handles any dust. $\$ 6.00$ Cadet. A favored small Duster for houschold

Major: Excellent hand Duster equipped with Hudson Crank. No. 603. Duraby built Duster with all working parts mounted on heavy bar frame. Brass indicator adjustable to any or more than 3 quarts. Shipping weight, 10 pounds. $\$ 9.50$. No. 604. Capacity, 5 to 10 pounds. Ship ping weight, 19 pounds. $\$ 13.50$.

foutstanding model for use on truck farms. Equipped with two 12 -inch cxtensions and
reversible nozzle. Will not clog. $\$ 1.00$, postpaid.

\section{SEEDERS}

Cahoon. Supcrior to all other hand Seeders. Use ful in broadcasting alfalfa, millet, grains, etc. Bag acres per hour. Shipping weight, 8 pounds. $\$ 5.00$ Cyclone. Inexpensive, simply constructed
Cymer. She $\$ 2.15$, postpaid.

\section{SUPPLIES PLANT.FOODS}

Prices on Plant-Foods customer pays transportation. When shipped by parcel post, add postage see page 22 for rates.
Prices are subject to change without notice.
Acid Phosphate. (16 per cent available.) Soluble, and used on soils requiring phosphoric
acid and lime. Bcncficial to root-crops. Apply 400 to 600 pounds to the acre. 10 Ibs. $30 \mathrm{c} ; 25 \mathrm{lbs}$. 50c;
$50 \mathrm{lbs} .95 \mathrm{c} ; 100 \mathrm{lbs}$. $\$ 1.75$; ton $\$ 28.00$. Aluminum Sulphate. Especially good for use around azaleas and camellias. 10 Ibs. $50 \mathrm{c} ; 25 \mathrm{Ib}$
$\$ 1.00 ; 50 \mathrm{Ibs}$. $\$ 1.50 ; 100 \mathrm{Ibs} . \$ 2.50$; ton $\$ 47.50$.
Bone Meal (Fine-ground). A plant-food esp Bone Meal (Fine-ground). A plant-food espe-
cially adapted to use on lawns and gardens, and of ounces per square yard; for top-dressing lawns use
one-half this quantity. 10 lbs. $50 \mathrm{c} ; 25 \mathrm{Ibs}$. $\$ 1.00$; 50 lbs. $\$ 1.75 ; 100$ lbs. $\$ 3.00$; ton $\$ 55.00$.
Cotton Seed Meal. (For fertilizer.) Rich in
nitrogen and potash. Used principally on trucknitrogen and potash. Used principally on truck-
farms, but also suitable for lawns. Apply 1500 to 3000 pounds to the acre. 10 lbs. $50 \mathrm{c} ; 25 \mathrm{Ibs} .75 \mathrm{c}$;
$50 \mathrm{lbs}$. $\$ 1.25$; $100 \mathrm{lbs}$. $\$ 1.75$; ton $\$ 25.00$. Floranid (Urea). Highiy concentrated nitrogenous fertilizer containing. 46 per cent available
nitrogen. Used during growing season to stimulate
growth. Use 2 ounces per square yard in the garden. growth. Use 2 ounces persquare yard in the garden,
For lawns, mix with four times its bulk of sand fine soil and spread at the rate of $1 / 2$ ounce per
square yard. Lb. 25c; 5 Ibs. 90c; 10 Ibs. $\$ 1.50$; Muriate of Potash. Excellent for potatoes and
ther root-crops. Apply several days before plantother root-crops. Apply several days before plant-
ing at the rate of 350 to 750 pounds pcr acre;
$5 \mathrm{lbs}$. $50 \mathrm{c} ; 10 \mathrm{lbs}$. $75 \mathrm{c} ; 25 \mathrm{lbs}$ \$1.25; $50 \mathrm{lbs}$. $\$ 1.75$. 100 Ibs. $\$ 3.00$; ton $\$ 55.00$.
Nitrophoska. The complete fertilizer. Contain 15 per cent nitrogen, 30 per cent phosphoric acid,
15 per cent potash. Excellent for lawns and 15 per cent potash. Excellent for lawns and
gardens. It stimulates strong, vigorous growth and

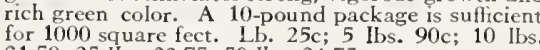
Nitrate of Soda. Provides nitrogen in a form that is immediately available to plants. Forces succulent growth. Must be uscd with care. Not
more than $11 / 2$ ounces per square yard or 500
pounds per acre, raked or harrowed. Water in thoroughly to prevent burning. One ounce to the $\$ 1.00 ; 50$ Ibs. $\$ 1.50 ; 100 \mathrm{Ibs}$. $\$ 2.50$; ton $\$ 17.50$.
Sheep Manure (Wizard Brand). Pulverized humus and plant-food to the soil. Especially suggested for use on flowers, vegetable gardens,
and lawns. Apply 500 to 1000 pounds per acre.
2 Ibs. $25 \mathrm{c} ; 5 \mathrm{lbs} 40 \mathrm{c} ; 10$ lbs. $60 \mathrm{c} ; 25 \mathrm{lbs}$ \$ $\$ 1.00$ 50 lbs. $\$ 1.50$; 100 lbs. $\$ 2.75$; ton $\$ 40.00$. Sulphate of Ammonia. A nitrogenous plant Iawns and discourages wecds. Usually used with other fcrtilizers. Mix with scvera
times its bulk of sand or soil ard

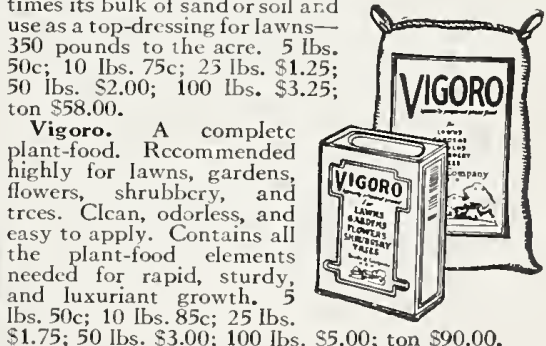

SPHAGNUM MOSS

Excellent for propagating, potting, and packing
lants. Bale $\$ 2.00$ f.o.b. New Orleans.

RAFFIA

For bunching veretables and tying flowers and grade. Lb. $40 \mathrm{c} ; 5$ Ibs. $\$ 1.50$, postpaid. Not pre
paid: 10 lbs. $\$ 2.50 ; 25$ lbs. $\$ 5.50 ; 100$ lbs. $\$ 21.00$.

PEAT MOSS

An imported brown virgin soil formed ages ago
by the decay of mosses, and various aquatic plants.
Makes soil more friable and improves drainage.
Its capacity to retain moisture will prove a great
help during dry weather. Fine for azaleas and roses.
The 2 -bushcl size will cover about 24 square feet
1 inch deep. 2 bus. $\$ 1.25$, postpaid. $1 / 2$ bale $\$ 1.75$
1 to 10 bales $\$ 3.00$ per bale; 10 bales or more $\$ 2.85$
per bale, f.o.b. New Orleans. 


\section{Place Orders Early-Choice Seed Supplies Are Short}

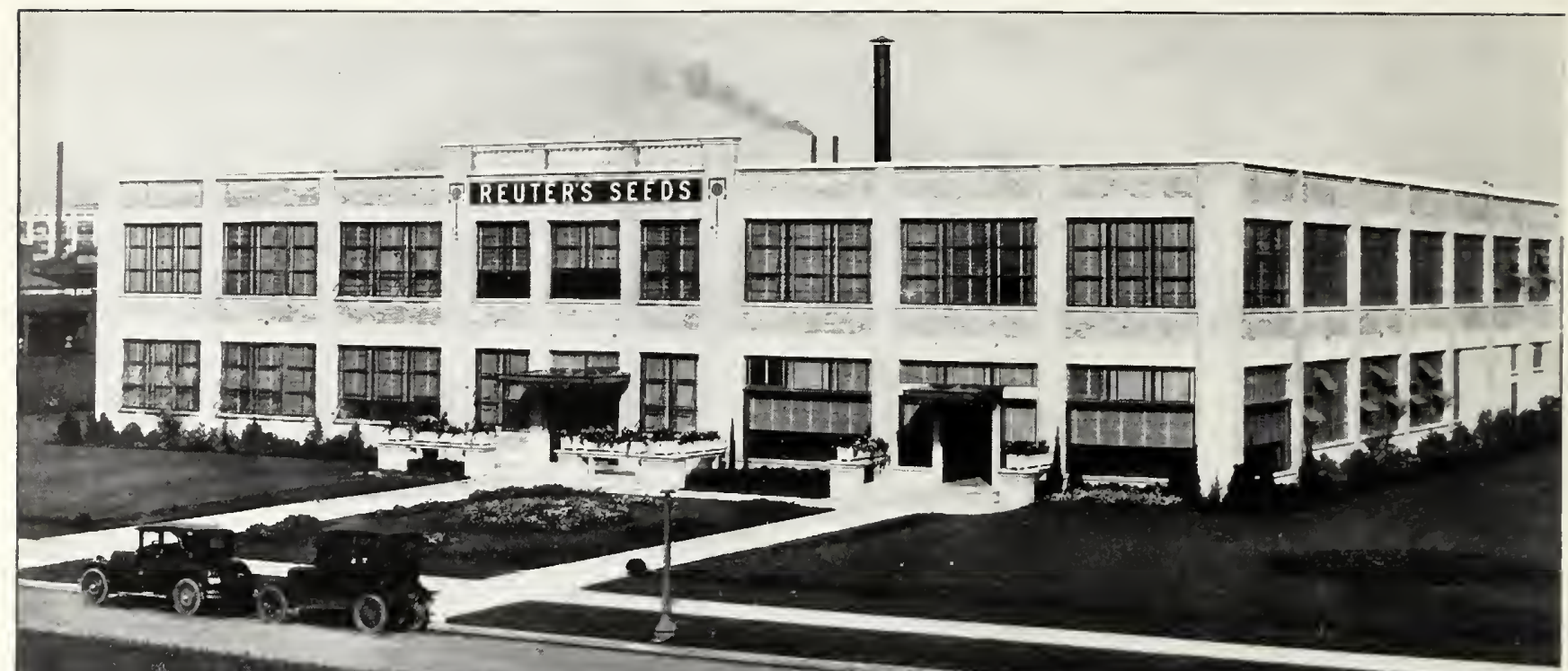

modern building at 320 North Carrollton Ave., New Orleans, La. Our customers and friends are cordially
invited to visit us when in the city

\section{SUGGESTIONS TO OUR CUSTOMER FRIENDS}

HOW TO ORDER. Please sign your name and full address on every order and letter you send us. Be sure to state just how you wish order shipped. Al ways write plainly.

C. O. D. ORDERS. No plants or roots will be sent C. O. D. We accept C. O. D. orders for seed only when 25 per cent of the amount of the order is paid in advance. A spccial C. O. D. arrangement applies to orders for Baby Chicks.

HOW TO SEND MONEY. Remit in any manner that suits your convenience. Send your personal check if it's easier. WVe will bear the cost of post office or express moncy order, or cost of registering letters from places that are not money-order offices. Deduct from the amount of the order.

STAMPS OR CASH. On orders where the amount is less than 50 cents, we will accept U. S. postage stamps in good condition (1- and 2-cent stamps preferred) the same as cash, but would ask those sending stamps to wrap them in oiled paper, if possible, to prevent their sticking together or to the order. Letters containing money should always be registered. Money in ordinary letters is unsafe.

WE PAY THE POSTAGE. AII seeds offered in this Catalog will be delivered to your door postpaid in any quantity up to 5 pounds in weight, except where otherwise noted. When larger quantities are offered at a reduced price "not prepaid," we do not pay transportation charges. We pay the postage on bulbs, except in larger quantities where a "not prepaid" price is named.

NURSERY STOCK. When we make a "postpaid" price, we ship by mail or express, at our option, and prepay the postage or express charges. When a "postpaid". price is not quoted in this Catalog, customer pays transportation charges. Our responsibility ceases upon delivery to the forwarding companies. Notify us promptly of loss or damage so we may help you collect from the express or railway companies.
NON-WARRANTY. In accordancc with the universal custom of the seed trade, Reuter Seed Co., Inc., gives no warranty, express or implied, as to description, quality, productivcness, or any ot her matter, of sceds, bulbs, or plants it sends out, and will not be in any way responsible for the crop. If the purchaser does not accept the goods on these terms they are at once to be returned. This does not mean that we Iack confidence in the seeds we sell, but we have no control over the seeds after they leave our possession, cspecially as to methods of planting, cultivating, and fertilizing, all of which are important factors in the success of any crop. Crops are dependent for success or failure on so many things besides seed that it is impossible for us to give any warranty or guarantee. If we should warrant or guarantee seeds in any way,

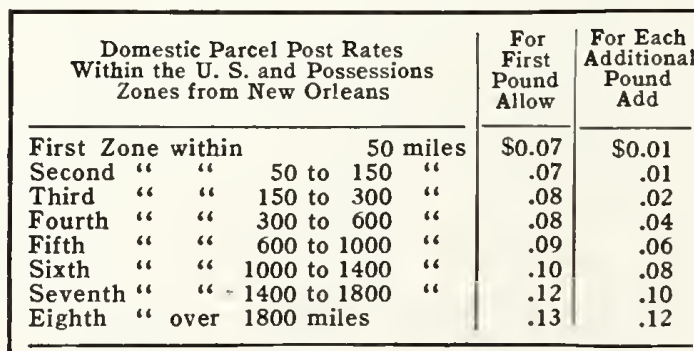

Parcel-Post packages are mailed anywhere within the United States or its possessions, weighing up to and including 70 pounds. Shipments of 20 pounds or over are as cheap if sent by express beyond the third zone. we could be held responsible for failure of the crop, regardless of cause, and this is a responsibility that we can not and will not accept. No responsible seedsman gives any warranty.

TESTED SEEDS. We conduct our own modern seed Iaboratory and trial-grounds. Our seeds are just as represented. If they prove otherwise, we will refill the order free of charge or refund the money you paid us for same.

ADVISORY SERVICE. We are glad to answer letters in detail regarding your garóen and farm problems, but all requests for information should be written on a separate sheet of paper, and not on orders. It is always a pleasure to help you make your garden a success, and we take pains to answer inquiries promptly and fully.

24-HOUR SERVICE. More than 95 per cent of all orders received are delivered to the post office, express, or freight station within twenty-four hours.

PRICE CHANGES. Wc are not bound for any definite time or quantity by the prices quoted in this Catalog, and they are subject to change without notice. We recommend that you order as early as possible. 
«« PLEASE USE THIS ORDER BLANK »»

F-32 Please Do Not Write in Above Space

Ship the following as per terms of your Descriptive Catalog:

State how you want goods shipped

by placing an $X$ in proper space.

Parcel Post $\square \quad$ Express $\square \quad$ Freight $\square$

Name

(Ladies please prefix Miss or Mrs.; the latter use husband's initials,

Write name and address very plainly.)

Street and No.

Post Office

Rural Route__Box No.

County State

Station or Exp. Office

Change of Address. $\begin{aligned} & \text { Please write your old address below, if you } \\ & \text { have moved since sending us your last order. }\end{aligned}$

\section{(Only if different from Post Office)}

\begin{tabular}{l|l}
\hline CATALOG \\
NUMBER \\
\hline
\end{tabular}

Approved By

Checked By

Shipped By

Filled By
IMPORTANT!

Be Sure to List Your ${ }^{\circ}$ Remittance Here

ENCLOSED PLEASE FIND Dollars

Draft or Check.

Money Order ...

Credit Check....

Currency ........

Postage Stamps.

Total Amount

When goods are wanted C.O.D.

$25 \%$ of the amount due must

accompany the order. No plants shipped C.O.D.

NOTE-If cash or stamps are sent by mail, Register the Letter.

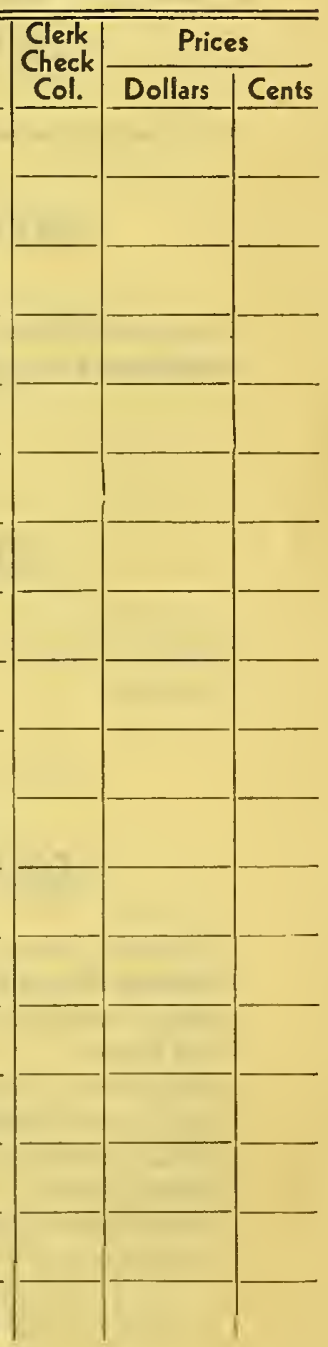




\section{Special Farm and Field Seed Prices}

PRICE LIST No. 6 • EFFECTIVE JULY 15, 1932

In the event prices are lower than here quoted when your order is received, you will receive remittance to cover balance due you. In case of advances in prices, seeds will be billed to you at prices prevailing at time order is received. If you desire to limit us to prices, please state so in your order, otherwise seeds will be shipped to you and invoiced accordingly.

TERMS. Our terms are cash with order, but if you do not desire to remit in full at the time you order, we will, if your order is accompanied by remittance of one-fourth of the amount of the order, make shipment, sending C.O.D. for balance due. We make no charge for boxes, bags, packing or drayage. All prices are F.O.B. New Orleans and subject to change without notice.

NON-WARRANTY. Reuter Seed Co., Inc., does not give, and its agents and employees are forbidden to give, any warranty, express or implied, as to description, quality, productiveness or any other matter of any seeds, bulbs, plants, etc., it sends out, and it will not be in any way responsible for the crop. If the purchaser does not accept the goods on these terms, it is to be returned at once, and if the money has been paid, it will be refunded.

\section{BE SURE TO REFER TO PRICE LIST NO. 6 WHEN YOU SEND IN YOUR ORDER}

\section{RECLEANED SEED OATS Per Bushel
Bus. (32 lbs.) 5 Bus. 10 Bus. Louisiana-grown Red Rustproof .\$0 $90 \quad \$ 0 \quad 80 \quad \$ 075$ 100-Bushel Red Rustproof . . . $90 \quad 90 \quad 75$}

\section{RECLEANED SEED RYE}

\begin{tabular}{|c|c|c|}
\hline Bus. (56 lbs.) & $\begin{array}{l}\text { Per } \\
5 \text { Bus. }\end{array}$ & $\begin{array}{l}\text { ushel } \\
\text { I0 Bus. }\end{array}$ \\
\hline$\$ 200$ & $\$ 190$ & $\$ 180$ \\
\hline 200 & 190 & 180 \\
\hline
\end{tabular}

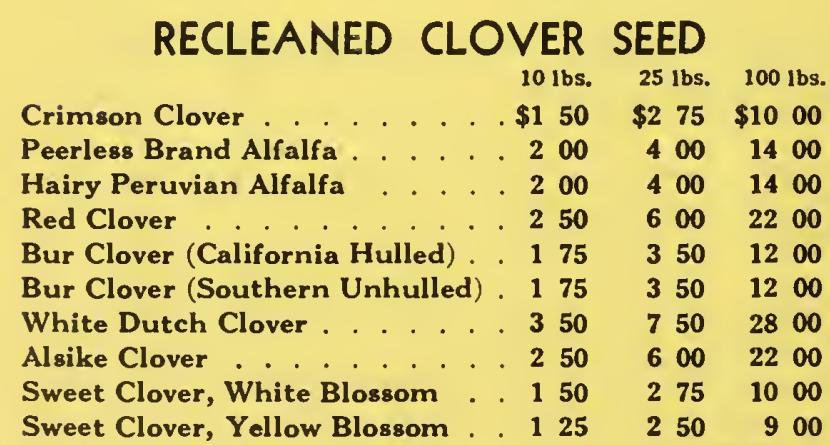

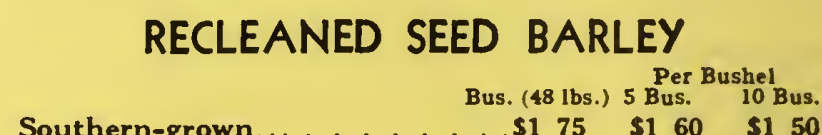

Southern-grown..... $\$ 175 \quad \$ 160 \quad \$ 150$

\section{RECLEANED GRASSES FOR LAWNS AND FARMS \\ Bermuda, Fancy $10 \mathrm{lbs}$. $\$ 275$ \\ Bermuda, Choice ..... 200 \\ Carpet .......... . 125 \\ Italian Rye (American-grown) . . 75 \\ $25 \mathrm{lbs} . \quad 100 \mathrm{lbs}$. \\ $\$ 600 \$ 2200$ \\ $450 \quad 1600$ \\ 250900 \\ $150 \quad 500$}




\section{Reuter's Baby Chicks Are Shipped to You C. O. D.}

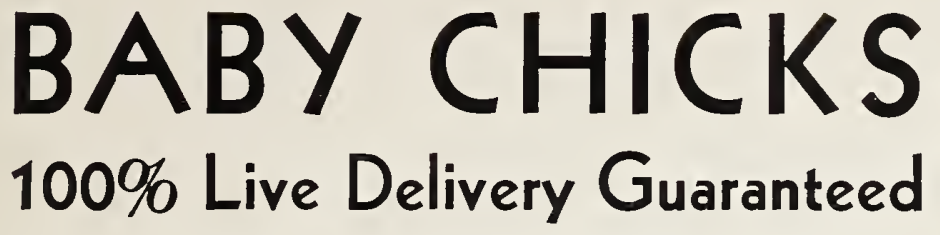

Baby Chicks of both of our strains are carefully selected for their vigor and healthiness. Though they are only one day old when shipped, we positively guarantee your receiving a full count of live, healthy Chicks. They have been so painstakingly bred from vigorous, high-quality, pure blood-line parent stock that we know they are well able to stand shipment. Like humans they will be tired when you receive them, but they will quickly revive and you will have a lively, healthy brood of Chicks that will rapidly develop into fine, fluffy fowls. Hundreds of voluntary testimonials from satisfied customers vouch for the truth of our guarantee.

\section{How to Order}

Place your order early! The earlier it is received the better service we will be able to render you at the time you wish your Baby Chicks delivered. Plainly state the number and breed of Chicks you wish, and always give a second choice of breed. In case we are unable to supply your first preference, we will ship the second breed named, unless otherwise instructed by you, thus saving unnecessary delay. Be sure to tell us when you wish to receive the Chicks. We ship Chicks by first-class mail and notify you well in advance just when to expect them. We furnish full instructions as to their immediate care. Shipments will be made C. O. D., unless you would rather send money order or check with your order.

\section{Reuter's SUPER-QUALITY Chicks}

Our SUPER-QUALITY Baby Chicks are Bred-toLay and Bred-to-Pay. Whether you buy an entire flock or only a sufficient number to build up the bloodline of your present flock, these extra-frne birds will prove an excellent investment. Every Chick is hatched from pedigreed blood-Iine parent stock that has been carefully rogued and culled, doubly assuring you of receiving only the strongest, healthiest Baby Chicks obtainable. Our Chicks come from record egg-laying liens, and are in every way real "top-notchers." They will quickly develop into fine, fluffy, high-powered, ego-producing fowls. You will greatly increase the profits from your chicken flock by ordering our SuperQuality Re-selected Strain of Baby Chicks.

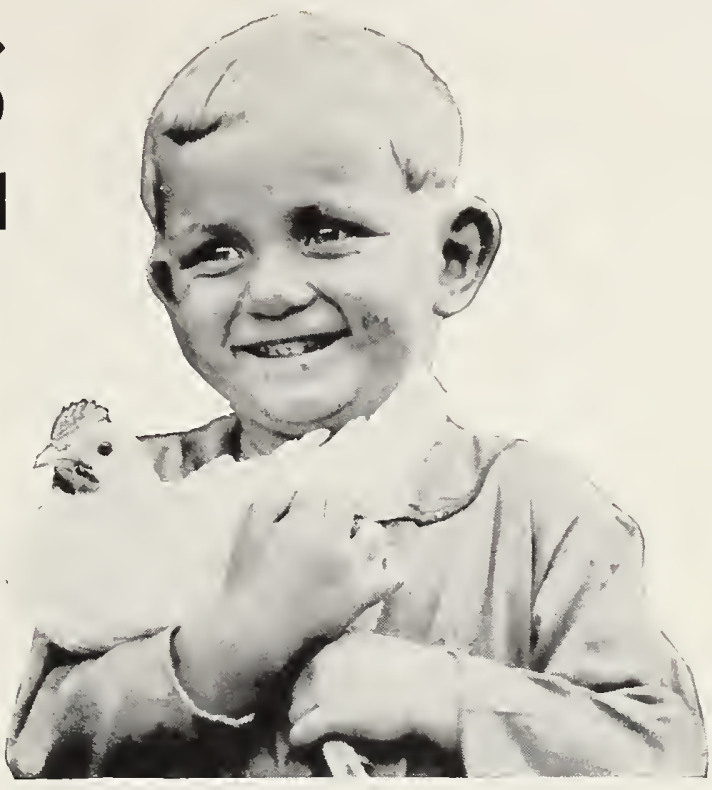

\section{You Pay Postman Upon Delivery}

Place your order now. It will guarantee you receiving the number and breed of your preference. You need not pay until the Chicks are safely delivered by the postman. Tell us when you wish to receive the Baby Chicks, and we will notify you just when they will be delivered to your very door by the postman. We assume all risk, and guarantee your receiving a full count of live, healthy Baby Chicks. No deposit required. You pay only upon actual receipt of your shipment of Chicks.

\section{Reuter's BREAK O'DAY Chicks}

A splendid, all-round, first-class grade of Baby Chicks, far better than those obtainable from most sources, which we are offering at REAL BARGAIN PRICES. We guarantee every Chick to be healthy, lively, and free of disease. Just the grade for building up a good general poultry flock. We are quoting these exceedingly low prices because of our sincere desire to help you cut expenses, and at the same time create a side-line that will prove a good way for you to make extra money. This is one way in which we are assisting you through this period of economy.

\section{POSTPAID PRICES FOR DELIVERY DURING} Reuter's SUPER-QUALITY Chicks

\begin{tabular}{|c|c|c|c|c|}
\hline S. C. White Leghorns & $\begin{array}{c}25 \text { Chicks } \\
\$ 300\end{array}$ & $\begin{array}{c}50 \text { Chicks } \\
\$ 550\end{array}$ & $\begin{array}{r}100 \text { Chicks } \\
\$ 1000\end{array}$ & $\begin{array}{r}500 \text { Chicks } \\
\$ 4500\end{array}$ \\
\hline S. C. Brown Leghorns & 300 & 550 & 1000 & 4500 \\
\hline C. Buff Leghorns & 325 & 600 & 1100 & 5000 \\
\hline arred Plymouth Rock & 325 & 600 & 1100 & 5000 \\
\hline C. R. I. Reds . . & 325 & 600 & 1100 & 5000 \\
\hline C. Black Minorcas & 325 & 600 & 1100 & 5000 \\
\hline uff Orpingtons . & 325 & 600 & 1100 & 5000 \\
\hline lottled Anconas. & 325 & 600 & 1100 & 5000 \\
\hline White Wyandottes & 375 & 700 & 1300 & 6000 \\
\hline White Rocks & 375 & 700 & 1300 & 6000 \\
\hline uff Rocks . & 375 & 700 & 1300 & 6000 \\
\hline White Rhode Islands & 375 & 700 & 1300 & 6000 \\
\hline lixed Chicks. & 250 & 450 & 800 & 3750 \\
\hline
\end{tabular}

JULY, AUGUST, SEPTEMBER AND OCTOBER

\begin{tabular}{|c|c|c|c|c|}
\hline \multicolumn{5}{|c|}{ Reuter's BREAK O'DAY Chicks } \\
\hline & 25 Chicks & 50 Chicks & 100 Chicks & 500 Chicks \\
\hline $\begin{array}{l}\text { S. C. White Leghorns } \\
\text { S. C. Brown Leghorns }\end{array}$ & $\begin{array}{r}. \$ 250 \\
. \quad 250\end{array}$ & $\begin{array}{r}\$ 450 \\
450\end{array}$ & $\begin{array}{r}\$ 8 \\
800\end{array}$ & $\begin{array}{r}\$ 3750 \\
3750\end{array}$ \\
\hline S. C. Buff Leghorns. & 275 & 500 & 900 & 4000 \\
\hline Barred Plymouth Rock & s. 275 & 500 & 900 & 4000 \\
\hline Rhode Island Reds. & . 275 & 500 & 900 & 4000 \\
\hline S. C. Black Minorcas & 275 & 500 & 900 & 4000 \\
\hline Mottled Anconas & 275 & 500 & 900 & 4000 \\
\hline Buff Orpingtons. & 275 & 500 & 900 & 4000 \\
\hline White Rocks . & 325 & 600 & 1100 & 5000 \\
\hline White Wyandottes & 325 & 600 & 1100 & 5000 \\
\hline White Rhode Islands & 325 & 600 & 1100 & 5000 \\
\hline Buff Rocks . . & 325 & 600 & 1100 & 5000 \\
\hline Mixed Chicks. & . 200 & 350 & 650 & 3000 \\
\hline
\end{tabular}

No order for less than 25 Chicks. Chicks shipped direct from hatchery, NOT from New Orleans 


\section{REUTER'S ZINNIAS}

Zinnias, in varied forms and colors, today claim a prominent place among the preferred annual garden flowers. For fall blooming they may be planted during July, August, and September. In 6 to 7 weeks the plants will begin to bloom, the flowers increasing in size and beauty of color as the plants mature. They delight in a sunny location provided with rich soil and abundant moisture.

\section{CALIFORNIA GIANTS}

The enormous flowers are flat and of symmetrical form.

2505 Grenadier. Rich, glowing deep red. Large and attractive. 2506 Lavender Gem. Lovely dcep lavender, turning to purple. 2507 Lemon Queen. Fine, clear lemon-orange shade.

2509 Miss Wilmott. A beautiful and delightful clear, soft pink. 2510 Orange Queen. Warm golden orange of perfect form.

2512 Purity. Magnificent pure white of enormous size.

2513 Rose Queen. Striking bright rose. Decided favorite. 2514 Scarlet Gem. Glowing scarlet. A gem in color and form. Each: Pkt. 15c; 1/40z. 45c; 1/20z. 75c; oz. $\$ 1.35$

2980 Daffodil. Bright canary-yellow. Pkt. 25c; 1/4oz. 75c; $1 / 2$ oz. $\$ 1.35$.

2515 California Giants Mixture. Every color available is represented. Pkt. $10 \mathrm{c} ; 1 / 4 \mathrm{oz}$. 35c; 1/2oz. 65c; oz. $\$ 1.10 ; 1 / 4 \mathrm{lb}$. $\$ 4.00$.

\section{GIANT DAHLIA-FLOWERED}

Resemble the Decorative Dahlia because of their unusual depth, open and graceful growth, and curled petals.

3065 Crown o' Gold. Each overlapping petal shows golden yellow at base and individual color at tip, giving flower twotone effect. Pkt. 30c; 3 for 75 c.

2125 Canary Bird. Giant primrose-yellow. Very showy.

2122 Crimson Monarch. Immense, flaming crimson blooms.

2124 Dream. Distinct deep lavender turning to purple.

2123 Exquisite. A plcasing light rose with Ty rian rose center.

2121 Illumination. Beautiful and striking deep carmine-rose.

2128 Oriole. Immense, bright, glistening orange and gold.

2126 Polar Bear. Magnificent pure white; large, well formed.

2127 Purple Prince. Beautiful, large, deep rhodamine-purple.

2935 Scarlet Flame. Bright scarlet, tinted orange.

Each: Pkt. 20c; $1 / 4$ oz. 60c; $1 / 20 z . \$ 1.10 ; 0 z . \$ 2.00$

2130 Giant Dahlia-flowered Mixture. An exeellent blend.

Pkt. 15 c; $1 / 4$ oz. 45c; $1 / 2$ oz. 80 c; oz. $\$ 1.50 ; 1 / 4$ lb. $\$ 5.50$.
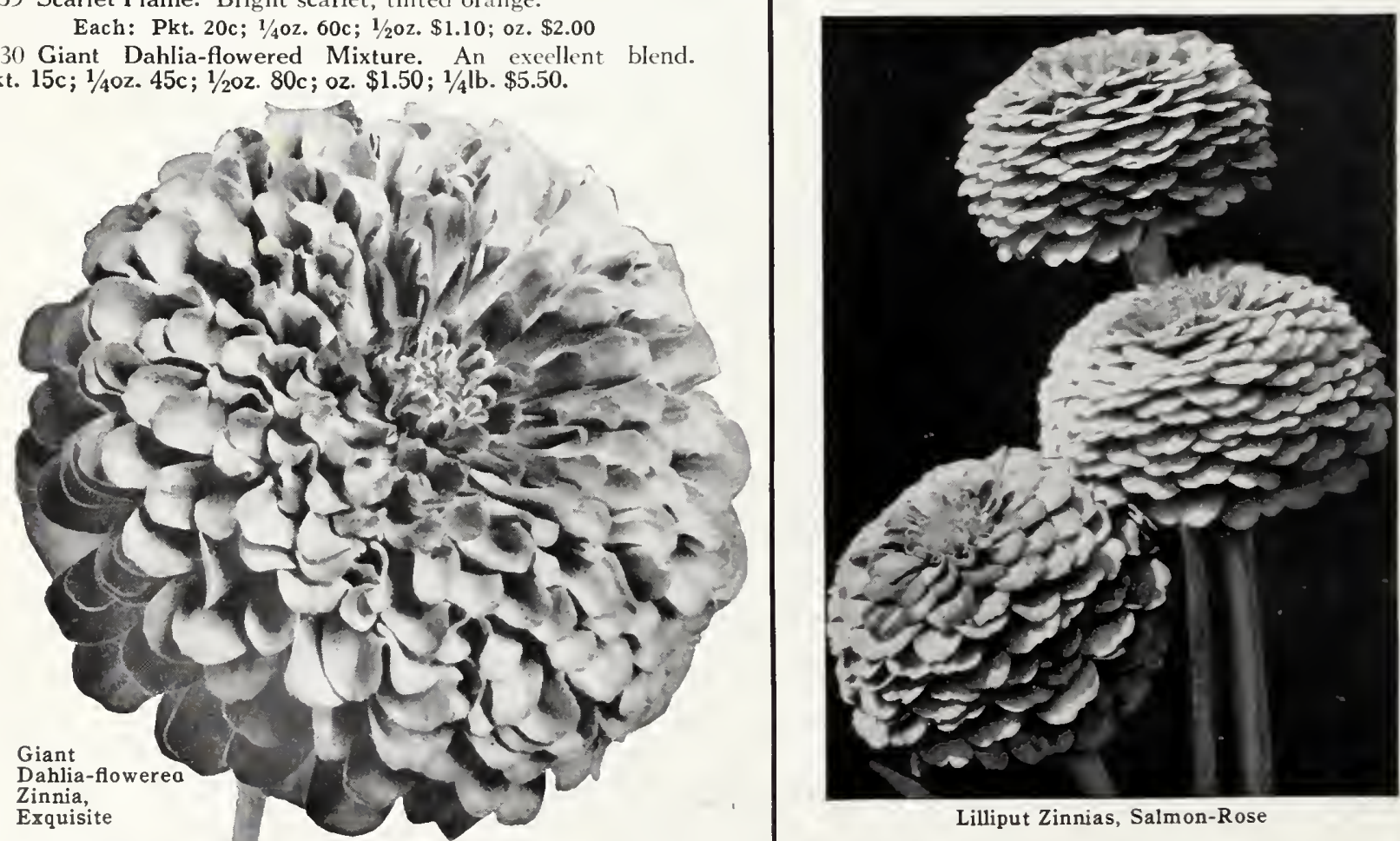

Lilliput Zinnias, Salmon-Rose

Elegant, small-flowering type with attractive, round, almost globular-shaped blooms resembling the pompon dahlias. Very prolific blooner

2147 Scarlet Gem 2958 Salmon-Rose

2148 Golden Gem 2962 Canary-Yellow

2955 White Gem 2965 Purple

Each: Pkt. 10c; 1/40z. 35c; 1/20z. 60c; 0z. $\$ 1.00$ 2146 Mixed Colors. Pkt. 10c; $1 / 4$ oz. 30c; $1 / 2$ oz. 50c; oz. $85 \mathrm{c}$.

\section{REUTER SEED CO., Inc. NEW ORLEANS, LOUISIANA}

